\title{
Melastomataceae das SerRas do município de Delfinópolis, Minas Gerais, Brasil
}

\author{
Marina Aparecida de Oliveira e Silva ${ }^{1,2}$ \& Rosana Romero ${ }^{1}$
}

\begin{abstract}
Resumo
(Melastomataceae das serras do município de Delfinópolis, Minas Gerais, Brasil). Um inventário florístico foi realizado entre abril de 2002 a novembro de 2003, e mais duas expedições em novembro de 2005 e outubro de 2006 nas serras do município de Delfinópolis, a sudoeste de Minas Gerais. Todos os espécimes coletados estão depositados no Herbarium Uberlandense (HUFU). As Melastomataceae são representadas por 52 espécies distribuídas em 17 gêneros. Miconia (17 spp.) é o gênero com o maior número de espécies, seguido por Microlicia (7 spp.), Leandra e Tibouchina (5 spp. cada), Svitramia (4 spp.) e Cambessedesia (3 spp.). Os gêneros Acisanthera, Chaetostoma, Clidemia, Comolia, Lavoisiera, Lithobium, Macairea, Marcetia, Ossaea, Pterolepis e Trembleya estão representados por uma espécie cada. É apresentada uma chave de identificação para as espécies, descrições, ilustrações e dados de distribuição geográfica das espécies.
\end{abstract}

Palavras-chave: cerrado, levantamento florístico, campo rupestre.

\section{Abstract}

(Melastomataceae from mountain of the municipality of the Delfinópolis, Minas Gerais, Brazil) A floristic survey of the mountain ranges of the municipality Delfinópolis, located in the southwestern portion of Minas Gerais state, was carried through between April, 2002 to November, 2003 and two additional expeditions carried out in November, 2005 and October, 2006. All specimens are deposited at Herbarium Uberlandense (HUFU). The Melastomataceae are represented with 52 species distributed in 17 genera. Miconia (17 spp.) are the genera with the largest number of species followed by Microlicia (7 spp.), Leandra and Tibouchina (5 spp. each), Svitramia (4 spp.) and Cambessedesia (3 spp.). The genera Acisanthera, Chaetostoma, Clidemia, Comolia, Lavoisiera, Lithobium, Macairea, Marcetia, Ossaea, Pterolepis and Trembleya are represented by a single species each. Key to the species, descriptions, illustrations, distribution are given. Key words: cerrado, floristic survey, 'campo rupestre'.

\section{INTRODUÇÃO}

Melastomataceae é constituída por aproximadamente 4.570 espécies distribuídas em 150 a 166 gêneros com distribuição pantropical com cerca de 3.000 espécies no neotrópico (Clausing \& Renner 2001). No Brasil ocorrem cerca de 68 gêneros e mais de 1.500 espécies (Romero \& Martins 2002).

Dentre as famílias de angiospermas, Melastomataceae está entre os mais importantes estudos florísticos e fitossociológicos no cerrado (Ribeiro et al. 1985; Munhoz 1996; Romero 1996; Mendonça et al. 1998; Araújo et al. 2002; Durigan et al. 2004; Siqueira et al. 2006) e nos campos rupestres (Giulietti et al. 1987; Pirani et al. 1994; Guedes \& Orge 1998; Munhoz \&
Proença 1998; Romero \& Martins 2002; Zappi et al. 2003; Matsumoto \& Martins 2005; Santos \& Silva 2005). Representantes da família estão presentes em praticamente todas as formações vegetacionais do cerrado com um número variável de espécies e grande diversidade de hábitos que permitem a ocupação de ambientes distintos e diversificados, com grande proporção de gêneros endêmicos (Romero \& Martins 2002).

Os gêneros que mais se destacam nos campos rupestres são Microlicia, Lavoisiera, Marcetia, Cambessedesia e Trembleya, enquanto os gêneros Leandra, Miconia, Ossaea e Tibouchina são gêneros de distribuição ampla nas formações florestais do neotrópico (Romero \& Martins 2002).

Artigo recebido em 04/2007. Aceito para publicação em 06/2008.

${ }^{1}$ Universidade Federal de Uberlândia, Instituto de Biologia, C.P. 593, 38400-902, Uberlândia, MG, Brasil.

${ }^{2}$ Autor para correspondência: marinaoliveiraesilva@yahoo.com.br 
O Parque Nacional da Serra da Canastra, segunda maior unidade de conservação de Minas Gerais, apresenta 95 espécies de Melastomataceae, das quais 10 são endêmicas e com ocorrência restrita aos campos rupestres (Romero \& Martins 2002). A região se situa como um entroncamento entre a Serra do Espinhaço e as Serras de Goiás, sendo que a grande maioria das espécies de Melastomataceae comuns nestas serras é típica de cerrado e campo rupestre (Romero \& Martins 2002).

Parte das serras do município de Delfinópolis está dentro dos limites do Parque Nacional da Serra da Canastra, mas até o momento não foi inteiramente desapropriada pelo governo federal. Aregião é considerada prioritária para a realização de levantamentos florísticos, uma vez que existem diversas localidades não protegidas por nenhuma unidade de conservação e totalmente desconhecidas (Romero \& Nakajima 1999; Drummond et al. 2005).

O presente estudo tem como objetivo apresentar as espécies de Melastomataceae que ocorrem nas serras do município de Delfinópolis, Minas Gerais.

\section{Material e Métodos \\ Área de estudo}

O município de Delfinópolis está a sudoeste do estado de Minas Gerais, entre as coordenadas $46^{\circ} 45^{\prime}$ a $47^{\circ} 00^{\prime} \mathrm{O}$ e $20^{\circ} 15^{\prime}$ a 20³0'S (Fig. 1). Sua extensão territorial é de $1.382,5 \mathrm{~km}^{2}$, os relevos predominantes são o montanhoso e o ondulado com algumas áreas planas na base das serras, e as altitudes variam de 660 m.n.m. a Represa dos Peixotos a 1.332 m.n.m na Serra Água Clara (IBGE 2004). O clima é ameno do tipo Cw na classificação de Köeppen, ou seja, Temperado Chuvoso e Quente (C) e com chuvas no verão (w), temperatura média anual de $21^{\circ} \mathrm{C}$, com média anual mínima de $15,5^{\circ} \mathrm{C}$ e máxima de $26^{\circ} \mathrm{C}$ e índice pluviométrico de 1.709 mm/ano (IBGE 2004).

Nas formações vegetacionais de maior destaque nas áreas de coleta foram encontrados diferentes tipos fitofisionômicos. Seguindo a terminologia utilizada por Ribeiro \& Walter (1998) e Pirani et al. (1994), as fitofisionomias que mais se destacam no município de Delfinópolis são: 1) os campos rupestres caracterizados pela presença de espécies

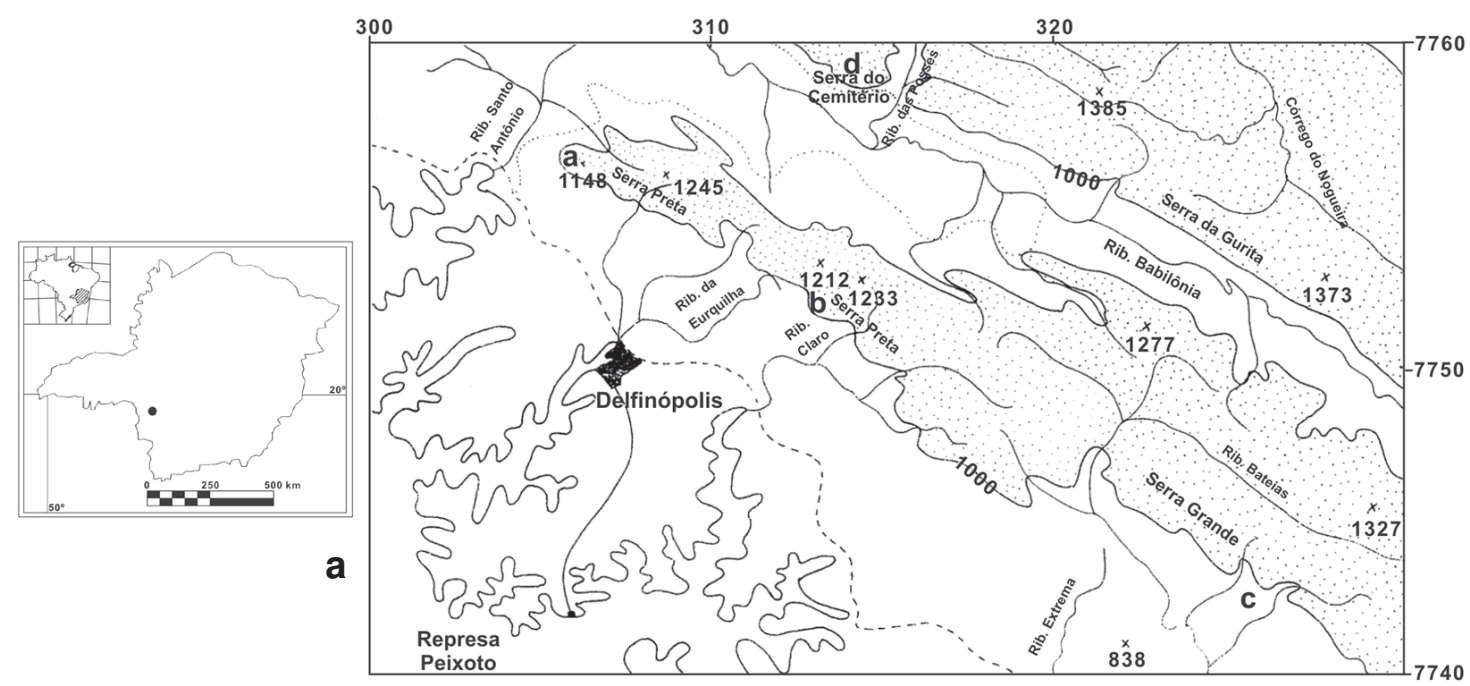

Figura 1 - a. Localização do município de Delfinópolis, Minas Gerais; b. localização das áreas de coletas nas serras do município de Delfinópolis. a: fazenda "Maria Concebida", rio Santo Antônio e estrada para Gurita; b: Fazenda "Paraíso", Fazenda do Sr. José Onório; c: "Paraíso Selvagem", d: Serra do Cemitério e Serra das Sete Voltas. (Fonte: adaptado de IBGE. 2a ${ }^{\text {a }}$ Ed. 1980 - Folha SF-23-V-A, escala 1:250.000) 
herbáceas, arbustivas e subarbustivas, com arvoretas de até dois metros de altura, e raramente, árvores maiores, encontrados em solo litólico em altitudes, geralmente, superiores a $900 \mathrm{~m}$ de altitude; 2) o campo limpo - caracterizado pela presença insignificante de subarbustos no estrato herbáceo, com subtipos de acordo com as condições topográficas e edáficas do solo; 3) o campo sujo - com subarbustos entremeados ao estrato herbáceo; 4) o campo úmido - presente em locais onde o lençol freático atinge a superfície; 5) o cerrado rupestre - um subtipo de vegetação arbóreo-arbustiva com altura média de dois a quatro metros e densidade variável dependente do volume de solo, que ocorrem entre afloramentos de rocha e podem formar trechos contínuos ou mosaicos com outros tipos de vegetação; 6) matas de galeria e mata ciliar formações florestais que ocorrem em locais mais profundos e férteis acompanhando cursos d'água; e 7) mata mesófila semidecídua - vegetação florestal situada em depressões geográficas, com ou sem a presença de cursos d'água.

\section{Coletas botânicas}

As espécies utilizadas neste trabalho são provenientes do levantamento florístico realizado em sete excursões com duração de uma semana, entre abril de 2002 e novembro de 2003 , e duas excursões adicionais realizadas em novembro de 2005 e outubro de 2006. Os exemplares herborizados e identificados encontram-se depositados no Herbarium Uberlandense (HUFU), do Instituto de Biologia da Universidade Federal de Uberlândia.

\section{Descrição morfológica}

As descrições morfológicas das espécies foram realizadas a partir da análise das exsicatas coletadas nas serras do município de Delfinópolis, exceto as descrições de frutos e sementes de Miconia calvescens, frutos de Microlicia isophylla e flores de Pterolepis repanda, frutos de Miconia chamissois e flores de Miconia minutiflora, descritos a partir de coletas citadas como 'material adicional examinado'.

As descrições das estruturas vegetativas e florais foram obtidas de material herborizado, adotando a terminologia de Radford (1986). Os dados de frutificação e floração foram obtidos das etiquetas de herbário. Os dados sobre distribuição geográfica de cada espécie foram compilados da literatura existente sobre a família (Martins et al. 1996; Romero 1996, Romero 2000; Goldenberg 2004; Matsumoto $\&$ Martins 2005).

\section{Resultados e Discussão}

Melastomataceae está representada nas serras do município de Delfinópolis por 52 espécies distribuídas em 17 gêneros. Os gêneros encontrados são Miconia (17 spp.), Microlicia (7 spp.), Leandra e Tibouchina (5 spp. cada), Svitramia (4 spp.) e Cambessedesia (3 spp.). Os gêneros Acisanthera, Chaetostoma, Clidemia, Comolia, Lavoisiera, Lithobium, Macairea, Marcetia, Ossaea, Pterolepis e Trembleya estão representados por uma espécie cada.

\section{Chave para identificação das espécies de Melastomataceae que ocorrem nas serras do município de Delfinópolis, Minas Gerais}

1. Fruto cápsula.

2. Folhas dispostas em pseudofascículos.

3. Pétalas inteiramente amarelas

2. Cambessedesia espora

3'. Pétalas com a metade inferior amarela e a metade superior vermelho-alaranjada.

4. Ramos jovens verdes a vináceos; ambas as faces da folha glabras, margem inteira, revoluta

3. Cambessedesia hilariana

4'. Ramos jovens nigrescentes; ambas as faces da folha piloso-glandulosas, margem levemente serreada, plana. 4. Cambessedesia regnelliana 
2'. Folhas opostas, verticiladas.

5. Flores trímeras, tetrâmeras ou hexâmeras.

6. Folhas sésseis.

7. Ambas as faces da folha e hipanto glabros, lâmina foliar com margem e nervura central calosas; flores hexâmeras; pétalas magenta; cápsula com deiscência da base para o ápice

8. Lavoisiera insignis

7'. Ambas as faces da folha e hipanto densamente hirsuto-glandulosos, canescentes, lâmina foliar com margem e nervura central lisas; flores tetrâmeras, pétalas brancas; cápsula deiscente do ápice para a base

16. Marcetia taxifolia

6'. Folhas pecioladas.

8. Ervas, ca. $10 \mathrm{~cm}$ alt.

9. Flores trímeras; pedicelo $5-30 \mathrm{~mm}$; hipanto piloso-glanduloso; 6 estames .... 14. Lithobium cordatum

9'. Flores tetrâmeras; pedicelo ca. $1 \mathrm{~mm}$; hipanto com tricomas penicilados; 8 estames

42. Pterolepis repanda

8'. Subarbustos ou arbustos, $0,5-2 \mathrm{~m}$ alt.

10. Pétalas púrpuras; estames antepétalos com apêndice ventral de $0,3-0,5 \mathrm{~mm}$ compr., bilobado; estilete $15-18 \mathrm{~mm}$ compr.

7. Comolia stenodon

10'. Pétalas lilases com a base creme; estames inapendiculados ventralmente; estilete $4-12 \mathrm{~mm}$ compr. 15. Macairea radula

5'. Flores pentâmeras.

11. Nervuras paralelódromas; hipanto com estrias calosas, cálice com coroa de cerdas rígidas

5. Chaetostoma pungens

11'. Nervuras acródromas; hipanto liso, cálice sem coroa de cerdas rígidas.

12. Ápice do ovário glabro.

13. Pétalas creme; ovário 5-locular

52. Trembleya phlogiformis

13'. Pétalas brancas, róseas, lilases, púrpuras ou magenta; ovário 3-locular.

14. Folhas com pecíolo 2-4 mm compr.; pedicelo 3-4 mm compr.; pétalas lilases

1. Acisanthera alsinaefolia

14'. Folhas sésseis ou com pecíolo 0,5-1 mm compr.; pedicelo 1-2,5 mm compr.; pétalas brancas, róseas, púrpuras ou magenta.

15. Pétalas brancas ou róseas

35. Microlicia euphorbioides

$15^{\prime}$. Pétalas púrpuras ou magenta.

16. . Ambas as faces da folha e hipanto com tricomas glandulares sésseis e pedicelados.

17. Lâmina foliar com margem inteira; pedicelo ca. $2 \mathrm{~mm}$ compr.; hipanto oblongo .... 34. Microlicia canastrensis

17'. Lâmina foliar com margem crenulada; pedicelo ca. $1 \mathrm{~mm}$ compr.; hipanto campanulado

38. Microlicia inquinans

16'. Ambas as faces da folha e hipanto com tricomas glandulares sésseis, desprovidos de tricomas glandulares pedicelados.

18. Estames antepétalos e ante-sépalos com filetes e anteras amarelos.

19. Indumento dos ramos e de ambas as faces da folha viloso; lâmina foliar com margem ciliado-glandulosa

36. Microlicia fasciculata 
19'. Indumento dos ramos e ambas as faces da folha hirsuto; lâmina foliar com margem longo ciliada, não glandulosa

40. Microlicia polystemma

18'. Estames antepétalos com filetes púrpuras e anteras amarelas; estames ante-sépalos com filetes e anteras púrpuras.

20. Folhas sésseis, margem da lâmina foliar inteira, não ciliada, 1-2 pares de nervuras acródromas basais 39. Microlicia isophylla

20 '. Folhas com pecíolo ca. $0,5 \mathrm{~mm}$ compr., margem da lâmina foliar ciliada, nervuras acródromas ausentes 37. Microlicia fulva

12'. Ápice do ovário com indumento variado, nunca glabro.

21. Inflorescência em dicásio.

22. Pétalas brancas.

23. Ramos, ambas as faces da folha e hipanto glabros

46. Svitramia sp. nov.

23'. Ramos, ambas as faces da folha e hipanto com tricomas

44. Svitramia integerrima

22'. Pétalas magenta.

24. Ramos e ambas as faces da folha com tricomas glandulares sésseis

43. Svitramia hatschbachii

24'. Ramos e ambas as faces da folha com tricomas adpresso-setosos

45. Svitramia pulchra

21'. Inflorescência em panícula, raro flores solitárias.

25. Árvores 2,5-5 m alt.; 1-2 pares de nervuras acródromas suprabasais

49. Tibouchina candolleana

25'. Arbustos ou subarbustos, 0,4-1,5 m alt.; 2-3 pares de nervuras acródromas basais.

26. Hipanto e lacínias do cálice com tricomas lepidotos; conectivo 2,5-5 mm compr.; estigma punctiforme

47. Tibouchina aegopogon

26'. Hipanto e lacínias do cálice com tricomas seríceos, setoso-seríceos ou estrigosos; conectivo 0,5-1 mm compr.; estigma truncado.

27. Hipanto campanulado; filetes glabros; estilete glabro

50. Tibouchina gracilis

27'. Hipanto oblongo; filetes com a metade inferior piloso-glandulosa; estilete setoso-seríceo.

28. Pecíolo 3-5 mm compr.; estilete ca. $8 \mathrm{~mm}$ compr.

48. Tibouchina bergiana

28'. Pecíolo 10-25 mm compr.; estilete 4-5 mm compr.

51. Tibouchina heteromalla

1'. Fruto baga.

29. Planta glutinosa, tricomas glandulares; hipanto urceolado; ovário 5-locular

6. Clidemia urceolata

29'. Planta não glutinosa, desprovida de tricomas glandulares; hipanto oblongo, campanulado a oblongo-campanulado; ovário (2)3-4-locular.

30. Inflorescências em cimeiras glomeriformes, axilares..... 41. Ossaea congestiflora 30'. Inflorescências em panículas, terminais ou laterais.

31. Pétalas lanceoladas, raro lineares, de ápice agudo ou acuminado.

32. Dois pares de nervuras acródromas suprabasais; flores hexâmeras; 12 estames; ovário 4-locular 12. Leandra melastomoides 
32'. Três a quatro pares de nervuras acródromas basais; flores pentâmeras; 10 estames; ovário 3-locular.

33. Lâmina foliar com base arredondada; estilete $12-12,5 \mathrm{~mm}$ compr.

34. Pecíolo 15-44 mm compr., face abaxial da folha vilosa, entremeada com tricomas dendríticos de superfície lisa, margem denteada; ovário com tricomas dendríticos no ápice

11. Leandra lacunosa

34'.Pecíolo 0,5-3,5 mm compr., face abaxial da folha híspido-estrigosa, entremeada com tricomas dendríticos de superfície rugosa, margem serreada; ovário com tricomas adpresso-setosos no ápice

10. Leandra coriacea

33'. Lâmina foliar com base subcordada; estilete 8,5-11 mm compr.

35. Arbustos, 1-1,5 m alt.; Panículas de glomérulos, 1,5-12 cm compr.; hipanto viloso, entremeado com tricomas dendríticos de ramificações curtas

9. Leandra aurea

35'. Subarbustos, ca. 0,6 m alt.; Panículas nunca de glomérulos, 14-20 cm compr.; hipanto híspido-estrigoso, desprovido de tricomas dendríticos

13. Leandra polystachya

31'. Pétalas ovais, obovais ou oval-oblongas, ápice arredondado, retuso ou subretuso.

36. Panículas de ramos escorpióides.

37. Indumento dos ramos, ambas as faces da folha e hipanto tomentoso-dendrítico, furfuráceo-dendrítico ou lepidoto-dendrítico.

38. Pecíolo 20-60 mm compr., estriado; panículas 12-29 cm compr.; ovário glabro ..

25. Miconia ferruginata

38'. Pecíolo 9-19 mm compr., não estriado; panículas 4-8 cm; ovário com tricomas dendríticos no ápice

22. Miconia cubatanensis

37'. Indumento dos ramos e hipanto lanoso ou tomentoso, nunca tomentoso-dendrítico, furfuráceo-dendrítico ou lepidoto-dendrítico.

39. Pétala com margem ciliado-glandulosa; estilete $8,5-9 \mathrm{~mm}$ compr. estigma truncado

24. Miconia fallax

39’. Pétalas com margem inteira; estilete 5,5-6 mm compr., estigma capitado

18. Miconia albicans

36'. Panícula de ramos nunca escorpióides.

40. Panículas de glomérulos.

41. Dois pares de nervuras acródromas basais; ovário com tricomas glandulares no ápice 19. Miconia calvescens

41'. Dois a quatro pares de nervuras acródromas suprabasais; ovário glabro ou com tricomas dendríticos ou setosos, nunca tricomas glandulares.

42. Flores tetrâmeras

29. Miconia pepericarpa

42'. Flores pentâmeras.

43. Margem da lâmina foliar inteira, não ciliada .... 21. Miconia chartacea

43'. Margem da lâmina foliar serreada ou denteada, ciliada.

44. Pecíolo 22-70 mm compr.; nervuras $20-70 \mathrm{~mm}$ suprabasais; ovário adpresso-setoso no ápice; estilete 7,5-9 mm compr.

30. Miconia pseudonervosa

44'. Pecíolo 4-7 mm compr.; nervuras 3-5 mm compr. suprabasais; ovário glabro; estilete ca. $4 \mathrm{~mm}$ compr. .. 6. Miconia ibaguensis

40'. Panículas nunca de glomérulos.

45. Ramos e ambas as faces da folha glabros. 
46. Lâmina foliar com margem serreada; anteras com 4 poros; ovário 2-locular 33. Miconia theaezans

46'. Lâmina foliar com margem inteira; anteras com 1 poro; ovário 3-locular 20. Miconia chamissois

45'. Ramos e ambas as faces da folha com indumento.

47. Dois pares de nervuras acródromas basais.

48. Indumento dos ramos e face abaxial das folhas ferrugíneo; ovário 3-locular. 49. Panículas 5-8 cm compr.; pétala com margem não ciliada

27. Miconia ligustroides

49'. Panículas 10,5-18 cm compr.; pétala com margem ciliado-glandulosa

31. Miconia rubiginosa

48'. Indumento dos ramos e face abaxial das folhas nunca ferrugíneos; ovário 4-locular. 50. Ápice da lâmina foliar agudo-apiculado; anteras com poro diminuto

17. Miconia affinis

50'. Ápice da lâmina foliar longo-acuminado; anteras com poro amplo

28. Miconia minutiflora

47'. Dois pares de nervuras acródromas suprabasais.

51. Lâmina foliar 8,5-13 ×2-3,5 cm; domácias foliares presente; conectivo ca. $5 \mathrm{~mm}$ prolongado abaixo das tecas 32. Miconia sellowiana

51'. Lâmina foliar 14-30 ×6,5-9,5 cm; domácias foliares ausente; conectivo ca. $3 \mathrm{~mm}$ prolongado abaixo das tecas 23. Miconia elegans

1. Acisanthera alsinaefolia (Mart. \& Schrank ex DC.) Triana, Trans. Linn. Soc. London 28(1): 34. 1871.

Fig. $2 \mathrm{a}-\mathrm{b}$

Ervas, ca. $30 \mathrm{~cm}$ ou subarbustos, ca. 60 $\mathrm{cm}$ alt. Ramos quadrangulares. Indumento dos ramos, faces adaxial e abaxial das folhas, hipanto e lacínias do cálice piloso-glanduloso, tricomas glandulares pedicelados. Folhas opostas, pecíolo 2-4 mm compr.; lâmina 17$27 \times 10-18 \mathrm{~mm}$, discolor, oval a lanceolada, ápice agudo a levemente acuminado, base arredondada, margem inteira, 2 pares de nervuras acródromas basais, proeminentes na face abaxial, impressas na face adaxial. Dicásios 5-12 cm compr., terminais e axilares; brácteas 4-10×1-4 mm, oblongas a elípticas, ápice agudo-apiculado, margem ciliadoglandulosa. Flores 5-meras; pedicelo 3-4 mm compr.; hipanto 4,5-5,5 $\times 3 \mathrm{~mm}$, campanulado; lacínias do cálice 4,5-6 ×0,5-1 mm, persistentes, triangulares a lineares, ápice agudo, terminando em um tricoma glandular pedicelado; pétalas $11-12 \times 3-5 \mathrm{~mm}$, lilases, obovais, ápice agudo-arredondado, margem esparsamente ciliado-glandulosa; estames 10 , desiguais, filetes glabros, anteras oblongas, levemente curvas, uniporosas; estames antepétalos com filetes ca. $5 \mathrm{~mm}$ compr., amarelos, anteras 5-6,5 ×0,5-1 mm, amarelas, conectivo ca. $0,5 \mathrm{~mm}$ compr. prolongado abaixo das tecas, apêndice ventral ca. 0,2 mm compr., bituberculado; estames ante-sépalos com filetes $5-7,5 \mathrm{~mm}$ compr., amarelos, ápice arroxeado, anteras 7-7,5 $\times 0,5-1 \mathrm{~mm}$, purpúreas, conectivo $2-2,5 \mathrm{~mm}$ compr. prolongado, apêndice ventral 0,5-1 mm compr., bituberculado; ovário 3-locular, livre, glabro; estilete $11,5-13 \mathrm{~mm}$, metade inferior amarela, metade superior púrpura, filiforme, glabro, estigma puntiforme. Cápsula $4-5 \times 4 \mathrm{~mm}$, castanha; sementes $0,5-1 \times 0,5 \mathrm{~mm}$, piramidais, superfície papilosa.

Material examinado: Fazenda Paraíso, estrada para Casinha Branca, 'Condomínio de Pedras', 11.IV.2002, fl., R. A. Pacheco et al. 155 (HUFU); idem, 5.XII.2002, fl. e bot., $R$. L. Volpi et al. 383 (HUFU); idem, 5.XII.2002, fl., fr. e bot., $R$. L. Volpi et al. 399 (HUFU); Fazenda Paraíso, trilha para Cachoeira Triângulo, 6.XII.2002, fl., fr. e bot., J. N. Nakajima et al. 3354 (HUFU); idem, 12.III.2003, fl. e fr., $R$. L. Volpi et al. 544 (HUFU); Fazenda Paraíso, trilha 
para Cachoeira Triângulo, 13.III.2003, fl. e fr., $R$. Romero et al. 6748 (HUFU).

Acisanthera alsinaefolia ocorre nos estados de São Paulo, Rio de Janeiro, Minas Gerais, Goiás e Mato Grosso do Sul. Esta espécie é encontrada em campo úmido, campo rupestre e cerrado rupestre das serras de Delfinópolis. Coletada com flores em março, maio e dezembro, e com frutos em março e dezembro.

\section{Cambessedesia espora subsp. ilicifolia} (DC.) A. B. Martins, Acta Bot. Bras. 9(1): 148. 1995.

Fig. 2 c

Ervas ou subarbustos, ca. $50 \mathrm{~cm}$ alt. Ramos simples ou ramificados, subcilíndricos, decorticantes, áfilos para a base. Indumento dos ramos setoso-dendrítico, faces adaxial e abaxial das folhas e bractéolas glabras, do hipanto e lacínias do cálice piloso-glanduloso, tricomas glandulares esparsos. Folhas em pseudofascículos, sésseis ou pecíolo ca. $0,5 \mathrm{~mm}$ compr.; lâmina 1,5-3,5 ×0,5-3 mm, concolor, oval a cordiforme, ápice agudo-acuminado, base arredondada a subauriculada, margem inteira ou levemente serreada, 2 pares de nervuras acródromas basais, par marginal inconspícuo, impressas na face adaxial e proeminentes na face abaxial. Bractéolas 1,52,5 × 1-2 mm, cordiformes, ápice agudoacuminado, margem ciliado-glandulosa. Flores 5-meras, solitárias, terminais ou axilares; pedicelo 0,5-1,5 $\mathrm{mm}$ compr.; hipanto 2,5-3,5 $\times 2-3 \mathrm{~mm}, 10$-estriado, campanulado; lacínias do cálice 1-3 × 2-2,5 mm, triangulares, ápice acuminado, margem inteira; pétalas 3,5-4,5× 2-2,5 mm, amarelas, oblongas a elípticas, ápice acuminado, margem não ciliada ou raramente ciliado-glandulosa; estames 10, subiguais, amarelos, filetes 3-4 mm compr., glabros ou com tricomas glandulares esparsos na metade inferior, anteras 2,5-4 ×0,5 mm, oblongas, curvas, uniporosas, conectivo espessado no dorso, não prolongado abaixo das tecas; ovário 3-locular, livre, com tricomas glandulares esparsos no ápice; estilete ca. $9 \mathrm{~mm}$ compr., amarelo, filiforme, levemente curvo no ápice, tricomas glandulares na metade inferior, estigma punctiforme. Cápsula 2,5-3,5×2-3,5 $\mathrm{mm}$, castanha; sementes ca. $1 \times 0,5 \mathrm{~mm}$, curvas, superfície tuberculada.

Material examinado: Fazenda Paraíso, estrada para Casinha Branca, 'Condomínio de Pedras', 8.X.2002, fl., fr. e bot., R. L. Volpi et al. 169 (HUFU); Serra do Cemitério, trilha do Zé Carlinho, 9.X.2002, fl. e fr., J.N. Nakajima et al. 3192 (HUFU); Estrada para a Gurita, 3.XII.2002, fl. e fr., R. L. Volpi et al. 284 (HUFU); Fazenda Paraíso, trilha para Cachoeira Triângulo, 13.III.2003, fl. e bot., R. Romero et al. 6745 (HUFU); idem, 23.X.2003, fl., fr. e bot., $R$. $L$. Volpi et al. 741 (HUFU); Fazenda Paraíso, trilha para Casinha Branca, 'Escada de Pedras', 14.IX.2004, fl. e fr., E. K. O. Hattori et al. 415 (HUFU); idem, 14.IX.2004, fl. e fr., J. N. Nakajima et al. 3844 (HUFU); idem, 14.IX.2004, fl., R. Romero et al. 7100 (HUFU).

Cambessedesia espora subsp. ilicifolia ocorre nos estados do Paraná, São Paulo, Minas Gerais, Mato Grosso, Goiás e no Distrito Federal. Nas serras de Delfinópolis, esta espécie ocorre em campo rupestre, cerrado rupestre e, ocasionalmente, em campo sujo com solo pedregoso. Coletada com flores em março e com flores e frutos em setembro, outubro e dezembro.

3. Cambessedesia hilariana (Kunth.) DC., Prodomus 3: 111. 1828.

Ervas, 10-20 cm alt., ou subarbustos, ca. $30 \mathrm{~cm}$ alt. Ramos quadrangulares, jovens verdes a vináceos, adultos decorticantes, áfilos para a base. Ramos e hipanto glabros ou com tricomas glandulares esparsos, faces adaxial e abaxial das folhas e lacínias do cálice glabras. Folhas em pseudofascículos, sésseis ou pecíolo 0,5-1 mm compr.; lâmina 1,5-7,5 × 0,5-2,5 $\mathrm{mm}$, concolor, oblongo-lanceolada a oboval, ápice agudo a arredondado, base atenuada, margem inteira, revoluta, 1 par de nervuras acródromas basais, impressas na face adaxial, proeminentes na face abaxial. Dicásios simples ou reduzidos, ou flores solitárias, terminais ou axilares; bractéolas 2-4 $\mathrm{mm}$ compr., cordiformes, ápice agudo, margem inteira ou levemente denteada, ciliado-glandulosa no ápice. Flores 5-meras; pedicelo 0,5-1 $\mathrm{mm}$ compr.; hipanto 3,5-5 ×2-3 mm, 10-estriado, oblongo; lacínias do cálice 1-2,5 × 1-2 mm, 

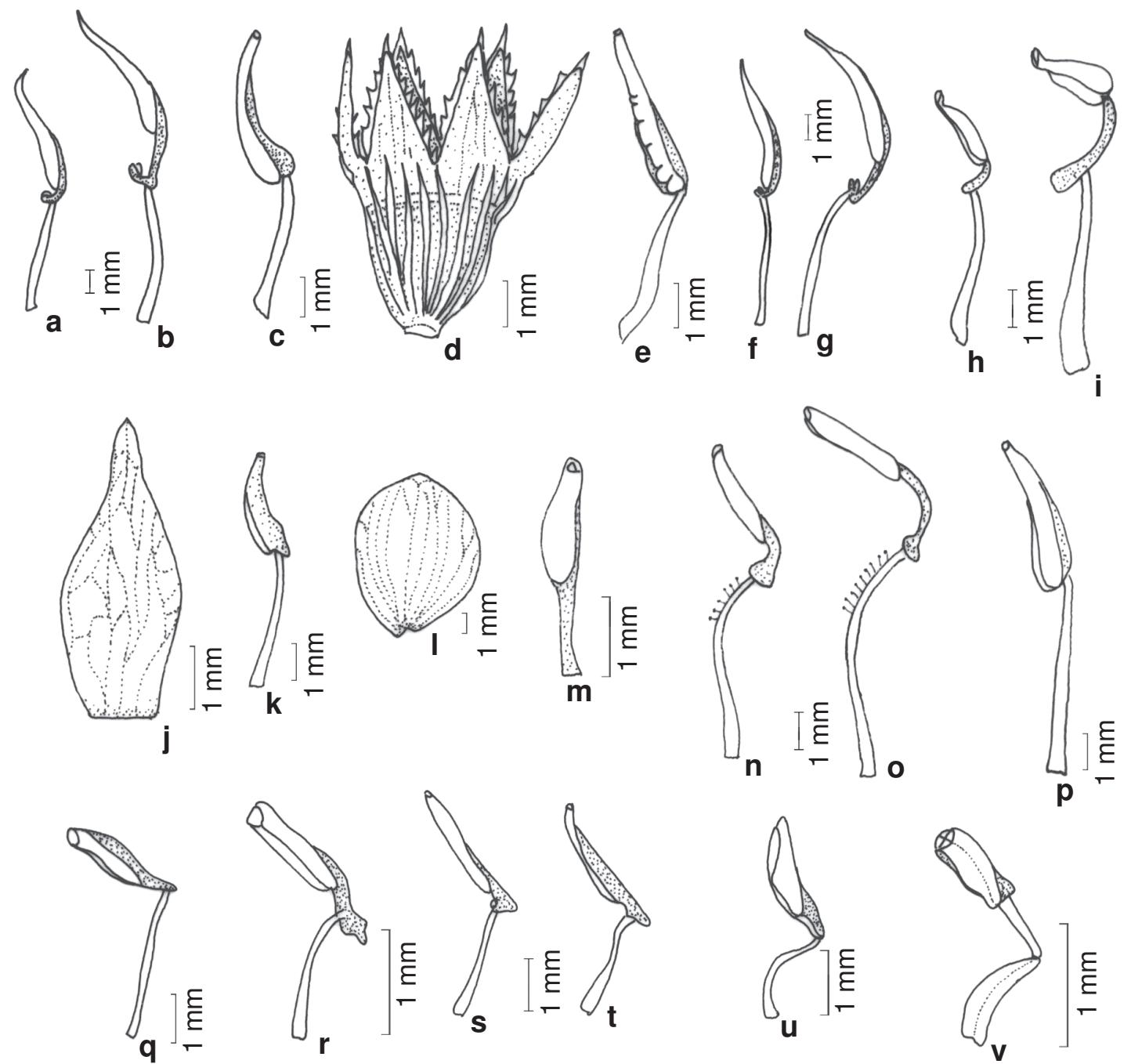

Figura 2 - a-b. Acisanthera alsinaefolia - a. estame antepétalo; b. estame ante-sépalo (Romero 6748). c. Cambessedesia espora subsp. ilicifolia - c. estame (Romero 6745). d. Chaetostoma pungens - d. hipanto (Romero 6676). e. Clidemia urceolata - e. estame (Romero 6991). f-g. Comolia stenodon - f. estame antepétalo; g. estame ante-sépalo (Romero 6454). h-i. Lavoisiera insignis - h. estame antepétalo; i. estame ante-sépalo (Nakajima 3658). j-k. Leandra aurea - j. pétala; k. estame (Nakajima 3184). 1-m. Lithobium cordatum-1. pétala; m. estame (Nakajima 3514). n-o. Macairea radula -n. estame antepétalo; o. estame ante-sépalo (Romero 7273). p. Marcetia taxifolia - p. estame (Nakajima 3204). q. Miconia chartacea - q. estame (Nakajima 3321). r. M. minutiflora - r. estame (Mota 118). s-t. M. rubiginosa - s. estame antepétalo; t. estame ante-sépalo (Romero 6369). u. M. sellowiana - u. estame (Nakajima 3564). v. M. theaezans - v. estame (Nakajima 3803).

lanceoladas a cordiformes, ápice agudoacuminado; pétalas 4-6 × 2-3,5 mm, metade inferior amarela, metade superior vermelhoalaranjada, elípticas, ovais ou obovais, ápice agudo a levemente acuminado, margem não ciliada; estames 10, desiguais, amarelos, filetes glabros ou com tricomas glandulares na metade inferior, anteras oblongas, uniporosas, conectivo espesso no dorso, não prolongado abaixo das tecas; estames antepétalos com filetes 3,5-5,5 mm compr., anteras 3-3,5 $\times 0,5$ $\mathrm{mm}$; estames ante-sépalos com filetes 4-6,5 mm compr., anteras 5-6,5 ×0,5-1 mm; ovário 3-locular, livre, tricomas glandulares esparsos no ápice; estilete 8-9 mm compr., amarelo, filiforme, levemente curvo no ápice, tricomas glandulares na metade inferior, estigma punctiforme. Cápsula 5,5-10 × 2,5-7 mm, 
castanha; sementes $0,5-1 \times 0,5 \mathrm{~mm}$, curvas, superfície tuberculada.

Material examinado: Fazenda Paraíso, estrada para Casinha Branca, 'Condomínio de Pedras', 8.X.2002, fl. e bot., R. L. Volpi et al. 213 (HUFU); Fazenda Paraíso, trilha para Casinha Branca, 'Escada de Pedras', 11.X.2002, fl., fr. e bot., R. Romero et al. 6423 (HUFU); idem, 5.XII.2002, fl., fr. e bot., $R$. $L$. Volpi et al. 403 (HUFU); idem, 10.III.2003, fl., fr., bot., R. A. Pacheco et al. 475 (HUFU); idem, 26.XI.2003, fl., fr. e bot., R. Romero et al. 6962 (HUFU); Paraíso Selvagem, trilha para a cachoeira Salto Solitário, 4.XII.2002, fl., fr. e bot., J. N. Nakajima et al. 3300 (HUFU); Estrada para a Gurita, 14.V.2003, fl., fr. e bot., R. A. Pacheco et al. 555 (HUFU); idem, 8.XI.2005, fl., fr. e bot., R. Romero et al. 7270 (HUFU).

Cambessedesia hilariana ocorre nos estados do Paraná, São Paulo, Minas Gerais, Goiás, Bahia, Pernambuco, Piauí e no Distrito Federal. Esta espécie é encontrada em campo rupestre e, ocasionalmente, em cerrado rupestre das serras de Delfinópolis. Coletada com flores e frutos nos meses de março, maio, outubro, novembro e dezembro.

4. Cambessedesia regnelliana Cogn., in Mart. \& Eichler Fl. bras. 14(3): 19. 1883.

Subarbustos, ca. 0,4 m alt. Ramos ramificados, quadrangulares, jovens nigrescentes, decorticantes, áfilos para a base. Indumento dos ramos, faces adaxial e abaxial das folhas, bractéolas e ápice do hipanto piloso-glanduloso, tricomas glandulares esparsos. Folhas em pseudofascículos, sésseis ou pecíolo 0,5-1,5 mm compr.; lâmina 5-9×2-5 mm, discolor, elíptica a oval, raramente oboval, ápice agudo, base atenuada, margem levemente serreada, ciliadoglandulosa, 1 par de nervuras acródromas basais, impressas na face adaxial, proeminentes na face abaxial. Dicásios, simples ou reduzidos, terminais; bractéolas 2,5-4 × 3-3,5 mm, cordiformes, ápice apiculado-glandular, margem ciliado-glandulosa. Flores 5-meras; pedicelo 0,5-1 mm compr.; hipanto 3-3,5×2,53,5 mm, 10-estriado, campanulado; lacínias do cálice 1-4 × 2-2,5 mm, ovais a cordiformes, ápice agudo-acuminado, margem inteira ou levemente crenada, ciliado-glandulosa; pétalas
5-7 $\times 4 \mathrm{~mm}$, metade inferior amarela, metade superior vermelho-alaranjada, elípticas, ovais ou obovais, ápice agudo a levemente acuminado, margem ciliado-glandulosa no ápice; estames 10, desiguais, amarelos, filetes glabros, anteras oblongas, uniporosas, tecas prolongadas abaixo do conectivo, conectivo espessado no dorso; estames antepétalos com filetes 3,5-4 mm compr., anteras 3-2,5×0,5 mm; estames ante-sépalos com filetes 4,5-6,5 mm compr., anteras 4,5-5×0,5 mm; ovário 3-locular, livre, tricomas glandulares esparsos no ápice; estilete 9,5-10 mm compr., amarelo, filiforme, levemente curvo no ápice, tricomas glandulares na metade inferior, estigma punctiforme. Cápsula 5-6×3,5-4,5 mm, castanha; sementes 0,5-1 $\times 0,5 \mathrm{~mm}$, curvas, superfície tuberculada. Material examinado: Serra do Cemitério, trilha do Zé Carlinho, 9.X.2002, fl., fr. e bot., J. N. Nakajima et al. 3205 (HUFU).

Cambessedesia regnelliana ocorre nos campos rupestres dos estados de São Paulo, Minas Gerais e Goiás. Nas serras de Delfinópolis ocorre somente em campo rupestre. Coletada com flores e frutos em outubro.

5. Chaetostoma pungens DC., Prodromus 3: 112. 1828.

Fig. 2 d

Subarbustos, 20-40 cm alt. Ramos cespitoso, cilíndricos, decorticantes, áfilos para a base. Ramos glabros ou com tricomas glandulares esparsos, faces adaxial e abaxial das folhas, hipanto e lacínias do cálice glabros. Folhas opostas, sésseis; lâmina 3-9,5 × 0,5-2 mm, concolor, lanceolada a triangular, ápice acuminado, curto-apiculado, base semiamplexicaules, margem calosa, inteira a levemente serreadociliada, 2-3 pares de nervuras, paralelódromas, nervura central calosa, demais tênues e inconspícuas, levemente impressas na face abaxial. Flores 5-meras, solitárias, terminais e axilares; sésseis ou pedicelo 0,5-1 mm compr.; hipanto 3-4×2-2,5 mm, oblongo-campanulado, estrias calosas proeminentes, cálice com coroa de cerdas rígidas; lacínias do cálice 2,5-5×0,5$1 \mathrm{~mm}$, triangular-lanceoladas, ápice acuminado, apiculado, margem calosa, serrilhado-ciliada; pétalas 6-13 × 4-6 mm, magenta, obovais, 
ápice assimétrico, levemente apiculado, margem não ciliada; estames 10, desiguais, filetes amarelos, glabros, anteras amarelas, linear-oblongas, ápice atenuado, uniporosas; estames antepétalos com filetes $3-4 \mathrm{~mm}$ compr., anteras $2,5-4 \times 0,5 \mathrm{~mm}$, conectivo ca. $1 \mathrm{~mm}$ compr. prolongado abaixo das tecas, apêndice ventral ca. $0,3 \mathrm{~mm}$ compr., levemente bituberculado; estames ante-sépalos com filetes 4,5-5,5 $\mathrm{mm}$ compr., anteras 4,5-5,5 $\times 1$ $\mathrm{mm}$, conectivo $0,5-1 \mathrm{~mm}$ compr. prolongado, apêndice ventral ca. $0,5 \mathrm{~mm}$ compr., bituberculado; ovário 3-locular, livre, glabro; estilete 5-8 mm compr., magenta, ereto, glabro, estigma punctiforme. Cápsula 3-5 ×2-4 mm, atropurpúrea; sementes $0,5-1 \times 0,5 \mathrm{~mm}$, curvas, superfície foveolada.

Material examinado: Fazenda Paraíso, trilha para Casinha Branca, 'Escada de Pedras', 11.IV.2002, fl., fr. e bot., R. A. Pacheco et al. 104 (HUFU); idem, 10.III.2003, fl., fr. e bot., $R$. A. Pacheco et al. 472 (HUFU); idem, 10.III.2003, fl. e fr., R.A. Pacheco et al. 473 (HUFU); idem, 10.III.2003, fl. e bot., R. L. Volpi et al. 489 (HUFU); Fazenda Paraíso, estrada para Casinha Branca, 'Condomínio de Pedras', 12.III.2003, fl., fr. e bot., R. L. Volpi et al. 585 (HUFU); idem, 17.V.2003, fl., fr. e bot., R. L. Volpi et al. 678 (HUFU); idem, 17.V.2003, fl., fr. e bot., R. L. Volpi et al. 712 (HUFU). Fazenda Paraíso, trilha para Cachoeira Triângulo, 13.III.2003, fl., fr. e bot., R. Romero et al. 6738 (HUFU); Estrada para a Gurita, 7.X.2002, fr., R. Romero et al. 6399 (HUFU); idem, 9.III.2003, fl., fr. e bot., R. Romero et al. 6676 (HUFU); idem, 14.V.2003, fr., R. A. Pacheco et al. 550 (HUFU).

Chaetostoma pungens ocorre nos estados do Paraná, São Paulo, Minas Gerais e Bahia. Esta espécie é encontrada principalmente em campos rupestres e, ocasionalmente, em cerrado rupestre e campo limpo com solo arenosopedregoso das serras de Delfinópolis. Espécie coletada com flores e frutos nos meses de março, abril e maio e com frutos em outubro.

6. Clidemia urceolata DC., Prodromus 3:158. 1828.

Fig. 2 e

Subarbustos, ca. 0,4 m alt., ou arbustos, 0,8-1,5 m alt., glutinosos. Ramos cilíndricos. Ramos, faces adaxial e abaxial das folhas, brácteas, hipanto e lacínias do cálice densamente revestidas de tricomas dendríticos e setoso-glandulares, cabeça glandular amarela. Folhas opostas, pecíolo 1-2 mm compr.; lâmina (6-)13,5-16,5×3-8 cm, discolor, oval-lanceolada, ápice agudo-acuminado, base cordada, margem levemente denteada, ciliado-glandulosa, $2-3$ pares de nervuras acródromas basais, par marginal inconspícuo, nervuras impressas na face adaxial, proeminentes na face abaxial. Panículas 2-7,5 cm compr., axilares; brácteas $3-4 \times 0,5 \mathrm{~mm}$, linear-triangulares, ápice apiculado. Flores 5meras; pedicelo $0,5-1 \mathrm{~mm}$ compr.; hipanto 55,5 × 3-4 mm, urceolado; cálice com lacínias internas 2,5-3 × 2,5-3 mm, ovais, ápice arredondado, margem ciliada, unidas na base, lacínias externas 2-2,5 × 0,5-1 mm, lineartriangulares, ápice apiculado; pétalas 5-6×3$4 \mathrm{~mm}$, branco-translúcidas, obovais, ápice arredondado, emarginado, margem não-ciliada; estames 10 , subiguais, creme, filetes $3-4 \mathrm{~mm}$ compr., glabros, anteras $3-4 \times 0,5 \mathrm{~mm}$, oblongas, curvas, uniporosas, conectivo não prolongado abaixo das tecas, inapendiculado; ovário 5-locular, livre, glabro; estilete 5-6 mm compr., creme, reto, glabro, estigma truncado. Baga 4-7 $\times 3-6 \mathrm{~mm}$, nigrescente; sementes $0,5-1 \times 0,5 \mathrm{~mm}$, curvas, superfície lisa.

Material examinado: Fazenda Paraíso, trilha para Casinha Branca, 'Escada de Pedras', 5.XII.2002, fl., fr. e bot., R. L. Volpi et al. 361 (HUFU); idem, 10.III.2003, fl., fr. e bot., R. L. Volpi et al. 497 (HUFU); idem, 15.V.2003, fl., fr. e bot., R. L. Volpi et al. 630 (HUFU); idem, 9.XI.2005, fl., fr. e bot., R. Romero et al. 7287 (HUFU). Paraíso Selvagem, trilha para mata do Canyon, 22.X.2003, fl., fr. e bot., J. N. Nakajima et al. 3562 (HUFU); Fazenda do Sr. José Onório, estrada para 'Escada de Pedras', 26.XI.2003, fl., fr. e bot., R. Romero et al. 6991 (HUFU); idem, 29.XI.2003, fl., fr. e bot., J. N. Nakajima et al. 3770 (HUFU).

Clidemia urceolata apresenta ampla distribuição, ocorrendo desde a América Central até o sudeste do Brasil. Nas serras de Delfinópolis, esta espécie ocorre em campo rupestre, cerrado rupestre, borda de mata de galeria e de mata mesófila semidecídua. Coletada com flores e frutos nos meses de março, maio, outubro, novembro e dezembro. 
7. Comolia stenodon (Naudin) Triana, Trans. Linn. Soc. 28(1): 37. 1871.

Fig. $2 \mathrm{f}-\mathrm{g}$

Arbustos ou subarbustos, $0,5-1 \mathrm{~m}$ alt. Ramos subquadrangulares, decorticantes, áfilos para a base. Indumento dos ramos, faces adaxial e abaxial das folhas, brácteas, hipanto e lacínias do cálice hirsuto-glanduloso. Folhas opostas, pecíolo 2-10 mm compr.; lâmina 1-5 $\times 5-2,5 \mathrm{~cm}$, concolor, oval, raramente lanceolada, ápice agudo, curto-apiculado, base arredondada, margem ciliado-glandulosa, 2 pares de nervuras acródromas basais, impressas na face adaxial, proeminentes na face abaxial. Dicásios simples $2-3,5 \mathrm{~cm}$ compr., ou flores solitárias, axilares; brácteas 2-3 $\times 0,5-1 \mathrm{~mm}$, oblongas, ápice agudoacuminado, margem ciliado-glandulosa; Flores 4-meras; pedicelo 2-3 mm compr.; hipanto 4$6 \times 4 \mathrm{~mm}$, oblongo-campanulado; lacínias do cálice 8-10×1-2 mm, linear a oblongas, ápice agudo-acuminado, margem ciliado-glandulosa; pétalas 15-16×7-10 mm, púrpuras, elípticas, ápice agudo a acuminado, margem ciliadoglandulosa no ápice; estames 8 , desiguais, filetes purpúreos, glabros, ou com tricomas glandulares esparsos, anteras amarelas com a base púrpura, ápice atenuado, uniporosas, conectivo púrpura; estames antepétalos com filetes $7-7,5 \mathrm{~mm}$ compr., anteras $5-7 \times 0,5 \mathrm{~mm}$, conectivo ca. $1 \mathrm{~mm}$ compr. prolongado abaixo das tecas, apêndice ventral $0,3-0,5 \mathrm{~mm}$ compr, bilobado; estames ante-sépalos com filetes ca. $10 \mathrm{~mm}$ compr., anteras $6,5-8 \times 1 \mathrm{~mm}$, conectivo 3-4 mm compr. prolongado, apêndice ventral ca. $0,5 \mathrm{~mm}$ compr., biauriculado; ovário 4-locular, livre, glabro; estilete 15-18 mm compr., metade inferior amarela, metade superior púrpura, filiforme, curvo no ápice, glabro ou com tricomas glandulares esparsos, estigma punctiforme. Cápsula 4-7 ×4-5 mm, atropurpúrea; sementes ca. $1 \times$ ca. $0,5 \mathrm{~mm}$, curvas, superfície foveolada.

Material examinado: Fazenda Paraíso, estrada para Casinha Branca, 'Condomínio de Pedras', 11.IV.2002, fr., R. A. Pacheco et al. 162 (HUFU); idem, 11.X.2002, fl., fr. e bot., R. Romero et al. 6454 (HUFU); idem, 9.XI.2005, fl., fr. e bot., R. Romero et al. 7295 (HUFU); Paraíso Selvagem, trilha para cachoeira Salto
Solitário, 4.XII.2002, fl., fr. e bot., J. N. Nakajima et al. 3327 (HUFU);

Comolia stenodon ocorre somente no estado de Minas Gerais, nas regiões sudoeste e central do estado. Nas serras de Delfinópolis ocorre em campo rupestre, capão de mata e afloramentos rochosos em mata de galeria. Coletada com flores e frutos de outubro a dezembro e com frutos no mês de abril.

8. Lavoisiera insignis DC., Prodromus 3:103. 1828.

Fig. 2 h-i

Arbustos ou subarbustos, 30-70 cm alt., eretos. Ramos ramificados, cilíndricos a subcilíndricos, decorticantes, áfilos para a base. Ramos glabros ou com tricomas glandulares esparsos, faces adaxial e abaxial das folhas, hipanto e lacínias do cálice glabros. Folhas opostas, sésseis, levemente côncavas, imbricadas; lâmina 3-11 ×2-7 mm, concolor, oval, ápice agudo, apiculado, margem calosa, ciliadoglandulosa, 1 par de nervuras acródromas basais, nervura central calosa, demais inconspícuas em ambas as faces. Flores 6-meras, solitárias, terminais; sésseis; hipanto ca. $3 \times 3 \mathrm{~mm}$, campanulado; lacínias do cálice 5-6×2-3 mm, oblongas, ápice acuminado, margem ciliadoglandulosa; pétalas 15-17×9-11 mm, magenta, obovais, ápice assimétrico, emarginadoacuminado, margem ciliado-glandulosa no ápice; estames 12, desiguais, filetes amarelos, glabros, anteras oval-oblongas, uniporosas, conectivo amarelo; estames antepétalos com filetes 55,5 mm compr., anteras 2-2,5 $\times 1 \mathrm{~mm}$, amarelas, conectivo ca. $1 \mathrm{~mm}$ compr. prolongado abaixo das tecas, apêndice ventral ca. 0,5 mm compr., obtuso; estames ante-sépalos com filetes 5$7 \mathrm{~mm}$ compr., anteras $2-2,5 \times 1 \mathrm{~mm}$, magenta, conectivo ca. $3 \mathrm{~mm}$ compr. prolongado, apêndice ventral ca. 1,5 mm compr., obtuso; ovário 6locular, adnato ao hipanto nos dois terços inferiores, glabro; estilete ca. 5,5 mm compr., amarelo, filiforme, glabro, estigma punctiforme. Cápsula 2-4 × 3-3,5 mm, deiscente da base para o ápice, atropurpúrea; sementes ca. $1 \times$ 0,5 mm, curvas, superfície foveolada.

Material examinado: Fazenda Paraíso, estrada para Casinha Branca, 'Condomínio de Pedras', 11.IV.2002, 
fl. efr., R. A. Pacheco et al. 160(HUFU); idem, 25.X.2003, fl., fr. e bot., J. N. Nakajima et al. 3658 (HUFU); Fazenda Paraíso, trilha para Casinha Branca, 'Escada de Pedras', 10.III.2003, fl., fr. e bot., R. L. Volpi et al. 481 (HUFU); idem, 15.V.2003, fl., fr. e bot., R. Romero et al. 6876 (HUFU); idem, 14.IX.2004, fl. e bot., $C$. A. Faria et al. 62 (HUFU); idem, 14.IX.2004, fl., fr. e bot., E. K. O. Hattori et al. 381 (HUFU); idem, 14.IX.2004, fl. e fr., R. Romero et al. 7105 (HUFU).

Lavoisiera insignis ocorre somente nas serras do Complexo Canastra, sudoeste do estado de Minas Gerais. Esta espécie ocorre em campo rupestre, campo sujo e em campo úmido associado a campo rupestre das serras de Delfinópolis. Coletada com flores e frutos nos meses de março a maio e em setembro e outubro.

9. Leandra aurea (Cham.) Cogn., in Mart. \& Eichler Fl. bras. 14(4): 142. 1886.

Fig. 2 j-k

Arbustos, 1-1,5 m alt. Ramos cilíndricos a subcilíndricos, glabrescentes. Indumento dos ramos e da face adaxial das folhas estrigoso, da face abaxial das folhas, brácteas, bractéolas, hipanto e lacínias do cálice viloso, entremeados com tricomas dendríticos de ramificações curtas. Folhas opostas, pecíolo 3-13 mm compr.; lâmina 3,5-11 ×1,5-5,5 cm, discolor, oval-lanceolada, ápice acuminado, base subcordada, margem serrilhada, ciliada, 3-4 pares de nervuras acródromas basais, par marginal tênue, nervuras impressas na face adaxial, proeminentes na face abaxial. Panículas de glomérulos 1,5-12 cm compr., terminais; brácteas $2-2,5 \times 1 \mathrm{~mm}$, ovallanceoladas a lineares, ápice agudo a acuminado, margem ciliada; bractéolas ca. $2 \times 0,5 \mathrm{~mm}$, oval-lanceolada, ápice agudo-acuminado, margem inteira, ciliada. Flores 5-meras, sésseis; hipanto ca. $4 \times 3 \mathrm{~mm}$, oblongo-campanulado; cálice com lacínias internas translúcidas, triangulares, ápice arredondado, margem ciliada, lacínias externas 2,5-3 ×0,5-1 mm, lineares, ápice agudo-acuminado, margem ciliada; pétalas ca. $4 \times 1 \mathrm{~mm}$, alvas, lanceoladas, ápice agudo, margem não ciliada; estames 10 , subiguais, vináceos, filetes 4-4,5 mm compr., glabros, anteras 3-3,5 × $1 \mathrm{~mm}$, subuladas, uniporosas; conectivo não prolongado abaixo das tecas, inapendiculado; ovário 3-locular, adnato ao hipanto nos dois terços inferiores, tricomas esparsos no ápice; estilete 9-11 mm compr., vináceo, filiforme, glabro, estigma punctiforme. Baga 2-4,5 ×2-3 mm, atropurpúrea; sementes ca. 1 x. 0,5 mm, piramidais, superfície lisa.

Material examinado: Serra do Cemitério, trilha do Zé Carlinho, 9.X.2002, fl. e bot., J. N. Nakajima et al. 3184 (HUFU); idem, 9.X.2002, fl., fr. e bot., J. N. Nakajima et al. 3219 (HUFU).

Leandra aurea é amplamente distribuída no neotrópico e, no Brasil, ocorre nos estados das Regiões Sul e Sudeste, na Bahia, Goiás e Distrito Federal. Nas serras de Delfinópolis, esta espécie ocorre exclusivamente em campo rupestre. Coletada com flores e frutos em outubro.

10. Leandra coriacea Cogn., in Mart. \& Eichler Fl. bras. 14(4):608. 1888.

Subarbustos, arbustos ou arvoretas, 0,5$2 \mathrm{~m}$ alt. Ramos cilíndricos, glabrescentes. Indumento dos ramos, face abaxial das folhas, brácteas, bractéolas, hipanto e lacínias do cálice híspido-estrigoso, entremeado com tricomas dendríticos, de superfície ramificada, da face adaxial das folhas densamente estrigoso. Folhas opostas, pecíolo 0,5-3,5 mm compr.; lâmina 3,5$12,5 \times 2-6 \mathrm{~cm}$, discolor, oval-lanceolada, ápice acuminado, base arredondada, margem serreada, ciliado-estrigosa, 3-4 pares de nervuras acródromas basais, par marginal tênue, nervuras impressas na face adaxial, proeminentes na face abaxial. Panículas de glomérulos 5-32 cm compr., terminais; brácteas ca. $13 \times 2,5 \mathrm{~mm}$, ovais, ápice agudo-apiculado, margem levemente serreada, ciliada; bractéolas 3-3,5 × $1 \mathrm{~mm}$, linear-oblongas, ápice agudoapiculado, margem ciliada. Flores 5-meras, sésseis; hipanto 5-6 × 3-4 mm, oblongocampanulado; cálice com lacínias internas translúcidas, triangulares, ápice arredondado, margem ciliada; lacínias externas 3-4,5×1 mm, lineares, ápice agudo-acuminado; pétalas 6-6,5 $\times 2-2,5 \mathrm{~mm}$, alvas, lanceoladas, ápice agudo, margem não ciliada; estames 10, subiguais, vináceos, filetes 4,5-5,5 mm compr., glabros, anteras 4-4,5 × $1 \mathrm{~mm}$, lineares, uniporosas, conectivo não prolongado abaixo das tecas, 
inapendiculado; ovário 3-locular, adnato ao hipanto nos dois terços inferiores, adpressosetoso no ápice; estilete ca $12 \mathrm{~mm}$ compr., vináceo, filiforme, glabro, estigma punctiforme. Baga 4-6 × 3-4 mm, atropurpúrea; sementes ca. $1 \times 0,5 \mathrm{~mm}$, ovais, superfície lisa.

Material examinado: Fazenda Paraíso, estrada para Casinha Branca, 'Condomínio de Pedras', 10.IV.2002, fr., R. Romero et al. 6306 (HUFU); idem, 25.X.2003, fl., fr. e bot., J. N. Nakajima et al. 3656 (HUFU); idem, 25.X.2003, fl. e bot., J. N. Nakajima et al. 3691 (HUFU); Estrada para a Gurita, 7.X.2002, fr., R. Romero et al. 6374 (HUFU); idem, 13.IX.2004, fl. e bot., E. K. O. Hatori et al. 357 (HUFU); Serra do Cemitério, trilha do Zé Carlinho, 9.X.2002, fl., fr. e bot., J. N. Nakajima et al. 3194 (HUFU); Fazenda Paraíso, trilha para Casinha Branca, 'Escada de Pedras', 11.X.2002, fl. e fr., R. Romero et al. 6415 (HUFU); idem, 14.IX.2004, fl., fr. e bot., J. N. Nakajima et al. 3817 (HUFU); idem, 14.IX.2004, fl., fr. e bot., E. K. O. Hatori et al. 409 (HUFU); idem, 14.IX.2004, fl. e bot., C. A. Faria et al. 36 (HUFU); idem, 9.XI. 2005, fl. e fr., R. Romero et al. 7286 (HUFU); idem, 9.XI.2005, fr., R. Romero et al. 7300 (HUFU); idem, 5.XII.2002, fl. e fr., R. L. Volpi et al. 356 (HUFU); idem, 5.XII.2002, fl., fr. e bot., R. L. Volpi et al. 390 (HUFU); idem, 5.XII.2002, fl. e fr., R. L. Volpi et al. 395 (HUFU); Paraíso Selvagem, trilha para mata do Canyon, 22.X.2003, bot., J. N. Nakajima et al. 3545 (HUFU); idem, 22.X.2003, fl. e bot., J. N. Nakajima et al. 3554 (HUFU); Fazenda Paraíso, trilha das cachoeiras, 23.X.2003, fl. e bot., $R$. L. Volpi et al. 742 (HUFU); idem, 23.X.2003, fl. e bot., J. N. Nakajima et al. 3592 (HUFU).

Leandra coriacea ocorre nas regiões sul e sudoeste do estado de Minas Gerais. Nas serras de Delfinópolis a espécie é encontrada em campo rupestre, cerrado rupestre e borda de mata mesófila semidecídua. Coletada com flores e frutos de setembro a dezembro e apenas com frutos em maio.

11. Leandra lacunosa Cogn., in Mart. \& Eichler Fl. bras. 14(4):138. 1886.

Arbustos, ca. $2 \mathrm{~m}$ alt., ou arvoretas, ca. 1,5 m alt. Ramos cilíndricos a subcilíndricos, glabrescentes. Indumento dos ramos com tricomas dendríticos curtos, face adaxial das folhas estrigosa, face abaxial viloso, com tricomas dendríticos de superfície lisa, das brácteas, bractéolas, hipanto e lacínias do cálice densamente viloso, com tricomas dendríticos, de ramificações longas. Folhas opostas, pecíolo (15-)40-44 mm compr.; lâmina 6-23 × 2,2-6 $\mathrm{cm}$, subdiscolor, oval a lanceolada, ápice acuminado, base arredondada, margem denteada, ciliada, 3 pares de nervuras acródromas basais, par marginal tênue, nervuras impressas na face adaxial, proeminentes na face abaxial. Panículas 7-13,7 cm compr., terminais; brácteas 4-6×1-2 mm, lanceolado-oblongas, ápice arredondado a acuminado, margem levemente denteada, ciliada; bractéolas 2-3,5 $\times 1 \mathrm{~mm}$, lanceoladas, ápice acuminado, margem levemente denteada, ciliada. Flores 5-meras, sésseis; hipanto 4-5×2,5-4 mm, campanulado; cálice com lacínias internas translúcidas, triangulares, ápice arredondado, margem ciliada, lacínias externas ca. $3 \times 1 \mathrm{~mm}$, lineares, ápice agudo a acuminado; pétalas 4-4,5 × 1,52,5 mm, alvas, lanceoladas, ápice agudo, margem não ciliada; estames 10, subiguais, vináceos, filetes 3-4 mm compr., glabros, anteras 4-5× $1 \mathrm{~mm}$, lineares, uniporosas, conectivo não prolongado abaixo das tecas, inapendiculado; ovário 3-locular, adnato ao hipanto nos dois terços inferiores, tricomas dendríticos no ápice; estilete 12-12,5 mm compr., vináceo, filiforme, glabro, estigma punctiforme. Baga ca. $4 \times 2,5-$ $3,5 \mathrm{~mm}$, atropurpúrea; sementes ca. $1 \times 0,5$ $\mathrm{mm}$, ovais, superfície lisa.

Material examinado: Serra do Cemitério, trilha do Zé Carlinho, 9.X.2002, fl. e bot., J. N. Nakajima et al. 3200 (HUFU); Fazenda Paraíso, trilha para cachoeira Triângulo, 6.XII.2002, fl. e fr., J. N. Nakajima et al. 3412 (HUFU); idem, 6.XII.2002, fl. e fr., J. N. Nakajima et al. 3424 (HUFU).

Leandra lacunosa ocorre nos estados de São Paulo, Espírito Santo, Minas Gerais, Goiás e no Distrito Federal. Esta espécie ocorre em capão de mata e campo rupestre das serras de Delfinópolis. Coletada com flores em outubro e flores e frutos em dezembro.

12. Leandra melastomoides Raddi, Piante nuove del Bras. 7. 1820.

Arbustos, arvoretas ou árvores, 2,5-4 m alt. Ramos subcilíndricos, glabrescentes. Indumento dos ramos, face adaxial das folhas, 
brácteas e bractéolas híspido-estrigoso, hipanto e lacínias do cálice densamente setoso, da face abaxial das folhas viloso-estrigoso. Folhas opostas, pecíolo 0,4-1 cm compr.; lâmina 9$19 \times 2,6-6 \mathrm{~cm}$, discolor, oblonga, ápice agudo, base atenuada a cuneada, margem levemente denteada, ciliada, 2 pares de nervuras acródromas, (1-) 2,2-2,4 cm suprabasais, nervura central adpresso-setosa, nervuras impressas na face adaxial, proeminentes na face abaxial. Panículas 4,8-11 cm compr., terminais; brácteas 5-7 × 2,5-5 mm, ovaloblongas, ápice agudo-arredondado, margem ciliada; bractéolas 5,5-6 × 1-2 mm, linearoblonga, ápice agudo, margem ciliada. Flores 6-meras, sésseis; hipanto 4-5 × 2,5-3 mm, oblongo a campanulado; cálice com lacínias internas $0,5-2,5 \times 0,5-1 \mathrm{~mm}$, triangulares, ápice arredondado, margem ciliada, lacínias externas $1-2,5 \times 0,5 \mathrm{~mm}$, triangulares, ápice acuminado, margem ciliada; pétalas ca. $4 \times 1 \mathrm{~mm}$, alvas, lanceoladas, ápice acuminado, margem não ciliada; estames 12 , subiguais, filetes $5-6 \mathrm{~mm}$ compr., creme, glabros, anteras ca. $4 \times 1 \mathrm{~mm}$, arroxeadas, oblongas, uniporosas, conectivo ca. $0,5 \mathrm{~mm}$ compr. prolongado abaixo das tecas, inapendiculado; ovário 4-locular, adnato ao hipanto na metade inferior, ápice setoso; estilete ca. $10 \mathrm{~mm}$ compr., creme, filiforme, glabro, estigma punctiforme. Baga 4-5 × 3-4 $\mathrm{mm}$, atropurpúrea; sementes ca. $1 \times 0,5 \mathrm{~mm}$, triangulares, superfície lisa.

Material examinado: Paraíso Selvagem, trilha para cachoeira do Alpinista, 4.XII.2002, fl. e bot., J. N. Nakajima et al. 3349 (HUFU); idem, 16.V.2003, fl. e fr., R. A. Pacheco et al. 565 (HUFU); idem, 15.IX.2004, fr., C. A. Faria et al. 80 (HUFU); idem, 15.IX.2004, fr., E. K. O. Hatori et al. 440 (HUFU); Paraíso Selvagem, trilha para cachoeira Salto Solitário, 11.III.2003, fl. e fr., R. Romero et al. 6709 (HUFU).

Leandra melastomoides ocorre na América do Sul, com registro no Suriname e, no Brasil, nos estados de Santa Catarina, Paraná, São Paulo, Rio de Janeiro, Espírito Santo, Minas Gerais, Goiás e Pará. Nas serras de Delfinópolis é encontrada em mata ciliar, mata de galeria e no interior de mata mesófila semidecídua e de capão de mata em vertente de cachoeira. Coletada com flores nos meses de março, maio e dezembro e com frutos em março, maio e setembro.

13. Leandra polystachya (Naudin) Cogn., in Mart. \& Eichler Fl. bras. 14(4): 132. 1886.

Subarbustos, $60 \mathrm{~cm}$ alt. Ramos subcilíndricos. Indumento dos ramos, hipanto e lacínias do cálice híspido-estrigoso, da face abaxial das folhas, brácteas, bractéolas viloso, entremeado com tricomas dendríticos, da face adaxial das folhas estrigoso. Folhas opostas, pecíolo 2-5 mm compr.; lâmina 8,2-4,5 ×2,5$6,1 \mathrm{~cm}$, subdiscolor, oval, ápice acuminado, base subcordada, margem denteada, ciliadoestrigosa, 3-4 pares de nervuras acródromas basais, par marginal tênue, nervuras impressas na face adaxial, proeminentes na face abaxial. Panículas $14-20 \mathrm{~cm}$ compr., terminais; brácteas $2,5-3 \times 1 \mathrm{~mm}$, triangular-lanceoladas, ápice acuminado, margem ciliada; bractéolas 1-2 $\times 0,5-1 \mathrm{~mm}$, triangulares, ápice acuminado, margem ciliada. Flores 5-meras, sésseis; hipanto 3-3,5 × $3 \mathrm{~mm}$, campanulado; cálice com lacínias internas translúcidas, triangulares, ápice arredondado, margem ciliada, lacínias externas $2-3 \times 0,5-1 \mathrm{~mm}$, lineares, ápice acuminado, margem ciliada; pétalas $4-4,5 \times$ 1-2 mm, alvas, lanceoladas, ápice acuminado, margem não ciliada; estames 10 , subiguais, vináceos, filetes $4-5 \mathrm{~mm}$ compr., glabros, anteras 3,5-4,5 $\times 1 \mathrm{~mm}$, lineares, uniporosas, conectivo não prolongado abaixo das tecas; ovário 3-locular, adnato ao hipanto nos dois terços inferiores, setoso no ápice; estilete 8,5$10 \mathrm{~mm}$ compr., vináceo, filiforme, levemente curvo no ápice, glabro, estigma punctiforme. Baga 4-4,5 ×3-4 mm, atropurpúrea; sementes ca. $1 \times 0,5 \mathrm{~mm}$, triangulares, superfície lisa.

Material examinado: Serra do Cemitério, trilha do Zé Carlinho, 9.X.2002, fl., fr. e bot., J. N. Nakajima et al. 3198 (HUFU).

Leandra polystachya ocorre nos estados de Santa Catarina, Paraná, São Paulo, Minas Gerais e no Distrito Federal. Nas serras de Delfinópolis ocorre exclusivamente em campo rupestre. Coletada com flores e frutos em outubro. 
14. Lithobium cordatum Bong., Mém. Imp. Sci. Saint Pétersbourg, Sér. 6 (4): 140. 1835.

Fig. $21-\mathrm{m}$

Ervas, ca. $10 \mathrm{~cm}$ alt. Caule curto, encrustado em fendas de rochas. Indumento do pecíolo, faces adaxial e abaxial das folhas e hipanto piloso-glanduloso, tricomas glandulares pedicelados, esparsos. Folhas opostas, pecíolo (5-)8-20 mm compr.; lâmina 4-11,5 ×4-9 mm, discolor, cordiforme, ápice obtuso a arredondado, base cordada, margem inteira, 1-2 pares de nervuras acródromas imperfeitas, nervuras secundárias decurrentes no pecíolo. Flores 3-meras, solitárias; pedicelo (5-)12-30 mm compr.; hipanto 1-1,5 × 1-1,5 $\mathrm{mm}$, campanulado, atropurpúreo; cálice com lacínias internas ca. $0,5 \times 1 \mathrm{~mm}$, triangulares, ápice arredondado, margem esparsamente ciliado-glandulosa, lacínias externas inconspícuas, ápice arredondado, com tricoma glandular único; pétalas 3-4 × 2,5-3,5 mm, róseas, obovais, ápice arredondado, raramente curto apiculado, margem não ciliada, às vezes ciliado-glandulosa no ápice; estames 6, iguais, filetes ca. 2,5 mm compr., vináceos, glabros, anteras ca. $1 \times 0,2 \mathrm{~mm}$, amarelas, clavadas, uniporosas, conectivo ca. $0,2 \mathrm{~mm}$ compr. prolongado abaixo das tecas, espessado no dorso, inapendiculado; ovário 3-locular, adnato ao hipanto nos três quartos inferiores, glabro; estilete ca. $4 \mathrm{~mm}$ compr., vináceo, filiforme, glabro, estigma truncado. Cápsula 2-2,5 × 1,5$2,5 \mathrm{~mm}$, atropurpúrea; sementes $0,2-0,3 \times 0,2$ $\mathrm{mm}$, curvas, superfície papilosa.

Material examinado: Fazenda Paraíso, trilha para Casinha Branca, 'Escada de Pedras', 11.V.2002, fl., R.A. Pacheco et al. 173 (HUFU); idem, 10.III.2003, fl., R.L. Volpi et al. 517 (HUFU); Fazenda Paraíso, estrada para Casinha Branca, 'Condomínio de Pedras', 12.III.2003, fl., R.L. Volpi et al. 571 (HUFU); idem, 17.V.2003, fl., R.A. Pacheco et al. 608 (HUFU); Fazenda Paraíso, trilha das cachoeiras, 13.III.2003, fl. e fr., J.N. Nakajima et al. 3514 (HUFU).

Lithobium cordatum, é endêmica do estado de Minas Gerais, com registro na região leste e sudoeste do estado. Encontrada em algumas fendas de rochas, em locais sombreados, nos campos rupestres, cerrado rupestre e mata de galeria das serras de
Delfinópolis. Coletada com flores e frutos nos meses de março e maio e frutos em março.

15. Macairea radula (Bonpl.) DC., Prodromus 3: 109. $1828 . \quad$ Fig. 2 n-o

Arbustos, 1-2 m alt. Ramos cilíndricos a subcilíndricos, decorticantes. Indumento dos ramos, bractéolas, hipanto e lacínias do cálice piloso-glanduloso, da face adaxial das folhas seríceo-estrigoso, face abaxial viloso, ambas as faces entremeadas com tricomas glandulares. Folhas opostas, pecíolo 0,5-2,2 cm compr.; lâmina 2,3-7,2×0,8-2,1 cm, concolor, oblonga a oboval, raramente elíptica, ápice obtuso, base atenuada, margem ciliada, face adaxial bulada, face abaxial foveolada, 2 pares de nervuras acródromas 2-4 mm suprabasais, raro basais. Dicásios 3,5-16,5 cm compr., terminais, simples ou ramificados; bractéolas $7-8,8 \times 1-1,5 \mathrm{~mm}$, lineares, ápice agudoapiculado, margem ciliada. Flores 4-meras; pedicelo 4-5 mm compr.; hipanto 2,5-3 $\times 2,5-$ $3 \mathrm{~mm}$, campanulado; lacínias do cálice 2,5-3,5 $\times 0,5-2 \mathrm{~mm}$, triangulares, ápice apiculado, margem ciliada; pétalas 8,5-11 × 4-6,5 mm, lilases com a base creme, oblongas a obovais, ápice agudo, acuminado ou arredondado, margem não ciliada; estames 8 , desiguais, filetes com tricomas glandulares na metade superior, anteras lineares, uniporosas, conectivo espessado no dorso, inapendiculados ventralmente; estames antepétalos com filetes 3,5-6,5 mm compr., amarelos, anteras 3-3,5× $0,5 \mathrm{~mm}$, amarelas, conectivo $1,5-2 \mathrm{~mm}$ compr., prolongado abaixo das tecas, expandido na região dorso-basal; estames ante-sépalos com filetes 5-9 mm compr., amarelos, purpúreos na base, anteras 3,5-4,5 ×0,5 mm, amarelas, purpúreas na base, conectivo 1,5-3,5 mm compr. prolongado, expandido na região dorsobasal; ovário 4-locular, livre, tricomas glandulares esparsos no ápice; estilete 4-12 $\mathrm{mm}$ compr., púrpura, filiforme, ápice levemente curvo, tricomas glandulares esparsos na metade inferior, estigma punctiforme. Cápsula loculicida 3-4 × 2-3 mm, atropurpúrea; sementes ca. 0,5 mm compr., subcocleadas, superfície tuberculada. 
Material examinado: Fazenda Paraíso, trilha para Casinha Branca, 'Escada de Pedras', 11.X.2002, fl., fr. e bot., R. Romero et al. 6444 (HUFU); idem, 14.IX.2004, fl., fr. e bot., C. A. Faria et al. 33 (HUFU); idem, 14.IX.2004, fl. e bot., R. Romero et al. 7104 (HUFU); idem, 14.IX.2004, fl., fr. e bot., J. N. Nakajima et al. 3815 (HUFU); idem, 14.IX.2004, fl., fr. e bot., E. K. O. Hattori et al. 402 (HUFU); idem, 9.XI.2005, fl. e bot., R. Romero et al. 7289 (HUFU); Fazenda Paraíso, estrada para Casinha Branca, 'Condomínio de Pedras', 25.X.2003, fl., fr. e bot., J. N. Nakajima et al. 3679 (HUFU); Estrada para a Gurita, 13.IX.2004, fl. e bot., C. A. Faria et al. 18 (HUFU); idem, 8.XI.2005, fl., fr. e bot., R. Romero et al. 7273 (HUFU).

Macairea radula ocorre na Bolívia e, no Brasil, nos estados de Santa Catarina, Paraná, São Paulo, Espírito Santo, Rio de Janeiro, Minas Gerais, Goiás, Mato Grosso, Bahia, Piauí e Maranhão. Nas serras de Delfinópolis esta espécie é encontrada principalmente em campo rupestre, próximo a cursos d'água e ocasionalmente em campo sujo. Coletada com flores e frutos em setembro, outubro e novembro.

16. Marcetia taxifolia (A.St.-Hil.) DC., Prodromus 3: 124. $1828 . \quad$ Fig. 2p

Subarbustos, $40 \mathrm{~cm}$ alt. Ramos ramificados, subcilíndricos, decorticantes, áfilos para a base. Indumento dos ramos, faces adaxial e abaxial das folhas, hipanto e lacínias do cálice hirsuto-glanduloso, tricomas glandulares, canescentes. Folhas opostas, sésseis; lâmina 1,5-2,5 × 0,5 mm, concolor, linear, ápice agudo-apiculado, base arredondada, margem revoluta, uma nervura central, impressa na face adaxial, proeminente na face abaxial. Flores 4-meras, solitárias, terminais ou axilares; pedicelo ca. $0,5 \mathrm{~mm}$ compr.; hipanto ca. $2 \times 1,5 \mathrm{~mm}$, campanulado, 8-estriado; lacínias do cálice ca. $2 \times 0,5 \mathrm{~mm}$, ápice agudo acuminado; pétalas ca. 2,5 × 1-2 $\mathrm{mm}$, brancas, oval-lanceoladas, ápice agudoacuminado, margem inteira; estames 8 , subiguais, amarelos, filetes 5-6 mm compr., glabros, anteras $2-3 \times 0,5 \mathrm{~mm}$, oblongas, uniporosas, conectivo não prolongado abaixo das tecas, espessado na porção basal, apêndice ventral ca. $0,3 \mathrm{~mm}$ compr., bilobado; ovário 4- locular, livre, glabro; estilete ca. $5 \mathrm{~mm}$ compr., creme a levemente arroxeado, filiforme, glabro, estigma punctiforme. Cápsula 2,5-3,5 ×2-2,5 $\mathrm{mm}$, castanha, deiscente do ápice para a base; sementes ca. $0,5 \times 0,5 \mathrm{~mm}$, subcocleadas, superfície foveolada.

Material examinado: Serra do Cemitério, trilha do Zé Carlinho, 9.X.2002, fl., fr. e bot., J. N. Nakajima et al. 3204 (HUFU).

Marcetia taxifolia ocorre na Venezuela, Guianas e Colômbia. No Brasil, é encontrada nos estados do Rio de Janeiro, Minas Gerais, Goiás, Bahia, Sergipe, Alagoas, Pernambuco, Ceará, Pará, Roraima e no Distrito Federal. Esta espécie é encontrada em campo rupestre das serras de Delfinópolis. Coletada com flores e frutos no mês de outubro.

17. Miconia affinis DC., Prodromus 3: 187. 1828.

Árvores, ca. $5 \mathrm{~m}$ alt. Ramos subcilíndricos a cilíndricos. Indumento dos ramos, faces adaxial e abaxial das folhas e hipanto moderadamente revestidos com tricomas dendríticos a glabrescentes. Folhas opostas, pecíolo 3-10 mm compr.; lâmina 7,6$18 \times 3-6 \mathrm{~cm}$, concolor, elíptica a lanceolada, ápice agudo-apiculado, base atenuada, margem inteira, não ciliada, 2 pares de nervuras acródromas basais, impressas na face adaxial, proeminentes na face abaxial. Panículas 310,5 cm compr., terminais. Flores 5-meras, sésseis; hipanto 2-2,5 mm compr., campanulado; cálice com lacínias curtas, caducas, triangulares, ápice arredondado; pétalas brancas, obovais, ápice arredondado, margem não ciliada; estames 10 , desiguais, anteras 2-3 mm compr., lineares, ápice truncado, uniporosas, conectivo 0,5$0,7 \mathrm{~mm}$ compr. prolongado abaixo das tecas, bilobado ventralmente nos estames antesépalos, formando uma bainha, calcarado dorsalmente nos estames antepétalos; ovário 4-locular, adnato ao hipanto na metade inferior, glabro; estilete glabro, estigma truncado. Baga nigrescente.

Material examinado: Paraíso Selvagem, cachoeira do Alpinista, 14.IV.2002, bt., R. L. Volpi et al. 157 (HUFU). 
Material adicional examinado: BRASIL, MINAS GERAIS: São Roque de Minas, Parque Nacional da Serra da Canastra, cachoeira Casca d'Anta, 21.III.1995, fr., R. Romero et al. 2073 (HUFU).

Miconia affinis ocorre desde o sul do México até a Amazônia e em formações florestais de São Paulo, Rio de Janeiro, Minas Gerais, Goiás, Bahia e Distrito Federal. Esta espécie é encontrada em mata ciliar das serras de Delfinópolis. Coletada com botões florais no mês de abril.

18. Miconia albicans (Sw.) Triana, Trans. Linn. Soc. Bot. 28: 116. 1871.

Arbustos, arvoretas ou árvores, 1,5-2,5 $\mathrm{m}$ alt. Ramos subcilíndricos, glabrescentes. Indumento dos ramos, face abaxial das folhas, nervuras, hipanto e lacínias do cálice lanoso, canescente, da face adaxial das folhas furfuráceo-dendrítico a glabrescente. Folhas opostas, pecíolo 9-13 mm compr.; lâmina 3,3$12,1 \times 1,4-5,3 \mathrm{~cm}$, discolor, elíptica a oval, raramente oboval, ápice agudo a curto acuminado, base arredondada a levemente cordada, margem inteira a levemente crenulada, 2 pares de nervuras acródromas basais, par marginal tênue, impressas na face adaxial, proeminentes na face abaxial. Panículas de ramos escorpióides 2,5-12,5 cm compr., terminais. Flores 5-6-meras, sésseis; hipanto 2,7-3,2 × 2,5-3 mm, campanulado; cálice com lacínias $0,5-1 \times 1 \mathrm{~mm}$, triangulares, ápice obtuso; pétalas $3-3,5 \times 2-2,5 \mathrm{~mm}$, brancas, obovais, assimétricas, ápice arredondado a subretuso, margem não ciliada; estames 10, desiguais, amarelos, filetes 3-3,5 mm compr., glabros, anteras $2-2,5 \times 0,5 \mathrm{~mm}$, oblongas, ápice atenuado, uniporosas, conectivo ca. $0,5 \mathrm{~mm}$ compr. prolongado abaixo das tecas, apêndice ventral ca. 0,5 mm compr., estames antepétalos com dois lobos ventrais e um calcar dorsal, estames ante-sépalos com lobos formando uma bainha; ovário 3-locular, adnato ao hipanto na metade inferior, glabro; estilete 5,5-6 mm compr., amarelo, reto, glabro, estigma capitado. Baga 4-5 × 3,5-5 mm, verde-jade; sementes ca. $1 \times 0,5 \mathrm{~mm}$, piramidais, superfície lisa.
Material examinado: Fazenda Paraíso, estrada para Casinha Branca, 'Condomínio de Pedras', 13.IV.2002, bt., R. L. Volpi et al. 98 (HUFU); Paraíso Selvagem, trilha para mata do Canyon, 22.X.2003, fl. e bot., J. N. Nakajima et al. 3555 (HUFU); Fazenda Paraíso, trilha para Casinha Branca, 'Escada de Pedras', 14.IX.2004, fl., fr. e bot., C. A. Faria et al. 66 (HUFU); idem, 14.IX.2004, fr. e bot., E. K. O. Hattori et al. 367 (HUFU); idem, 14.IX.2004, fl. e bot., R. Romero et al. 7065 (HUFU); Paraíso Selvagem, cachoeira do Alpinista, 15.IX.2004, bt., C. A. Faria et al. 70 (HUFU); idem, 15.IX.2004, bt., E. K. O. Hattori et al. 427 (HUFU); Estrada para a Gurita, 8.XI.2005, fr., R. Romero et al. 7276 (HUFU); idem, 21.X.2003, fl. e bot., J. N. Nakajima et al. 3533 (HUFU).

Miconia albicans é encontrada desde as Antilhas, sul do México até o Paraguai. No Brasil é encontrada em quase todos os estados, de Roraima e Amazonas até o Paraná. Nas serras de Delfinópolis esta espécie é comum em campo rupestre, cerrado rupestre e mata ciliar. Coletada com flores nos meses de abril, setembro e outubro e com frutos em outubro e novembro.

19. Miconia calvescens DC., Prodromus 3 : 185. 1828.

Arvoretas, ca. $2 \mathrm{~m}$ alt. Ramos subcilíndricos a cilíndricos, achatados no ápice. Indumento dos ramos, faces adaxial e abaxial das folhas, hipanto e lacínias do cálice pilosodendrítico, tricomas de ramificações longas. Folhas opostas, pecíolo 5,7-7,2 cm compr.; lâmina 8-26×4-13,3 cm, discolor, elíptica, oval a oboval, ápice agudo a curto acuminado, base arredondada, margem inteira a crenulada, 2 pares de nervuras acródromas basais, par marginal inconspícuo, nervuras proeminentes em ambas as faces. Panículas de glomérulos 9,5-13,5 cm compr., terminais. Flores 5-meras, sésseis; hipanto 1,5-2×1,5-2 mm, campanulado; cálice com lacínias ca. $0,5 \times 1 \mathrm{~mm}$, triangulares, ápice agudo a arredondado; pétalas $1-1,5 \times 1$ $\mathrm{mm}$, brancas, obovais, ápice arredondado, margem não ciliada; estames 10, subiguais, creme, filetes ca. $1 \mathrm{~mm}$ compr., glabros, anteras $1-1,5 \times 0,5 \mathrm{~mm}$, oblongas, ápice atenuado, uniporosas, conectivo ca. $0,5 \mathrm{~mm}$ compr. prolongado abaixo das tecas, trilobado, estames 
antepétalos glabros, estames ante-sépalos com tricomas glandulares sésseis na região ventral; ovário 3-locular, adnato ao hipanto na metade inferior, tricomas glandulares esparsos no ápice; estilete 1,5-2,5 mm compr., creme, reto, glabro, estigma subcapitado. Baga ca. $3 \times 3$ $\mathrm{mm}$, nigrescente; sementes ca. $1 \times 0,5 \mathrm{~mm}$, curvas, superfície tuberculada.

Material examinado: Estrada próxima ao rio Santo Antônio, 12.IV.2002, fl. e bot., J. N. Nakajima et al. 3152 (HUFU).

Material adicional examinado: BRASIL, MINAS GERAIS: São Roque de Minas, Parque Nacional da Serra da Canastra, guarita de Sacramento, 20.IX.1996, fr., R. Romero \& J. N. Nakajima 3568 (HUFU).

Miconia calvescens ocorre no Peru e Brasil, nos estados do Amazonasde Santa Catarina ao Amazonas, incluindo Pernambuco. Esta espécie é encontrada em mata mesófila semidecídua das serras de Delfinópolis. Coletada com flores no mês de abril.

20. Miconia chamissois Naudin, Ann. Sci. Nat., Ser. 3, Bot. 16:179. 1851.

Arbustos, ca. 1,5 m alt. Ramos cilíndricos, achatados no ápice. Ramos, faces adaxial e abaxial das folhas, hipanto e lacínias do cálice glabros. Folhas opostas, pecíolo 2,5-2,8 cm compr.; lâmina 13,5-18 ×7-12,6 cm, discolor, elíptica a oval, ápice agudo, base atenuada a levemente arredondada, margem inteira, 2 pares de nervuras acródromas, 2-7 mm compr. suprabasais, proeminentes em ambas as faces. Panículas 21-23,5 cm compr., terminais. Flores 5-meras, subsésseis; pedicelo ca. 0,5 mm compr.; hipanto ca. $2 \times 1,5-2 \mathrm{~mm}$, campanulado; cálice com lacínias internas ca. 0,5 × $1 \mathrm{~mm}$, triangulares, ápice agudo a arredondado, lacínias externas inconspícuas, ápice arredondado; pétalas 2,5-3,5 × 2-3 mm, brancas, obovais, ápice arredondado a subretuso, margem não ciliada; estames 10, desiguais, creme, filetes 2-2,5 mm compr., glabros, anteras 1,5-2 $\times 0,5 \mathrm{~mm}$, creme, oblongas, ápice atenuado, uniporosas, conectivo ca. $0,5 \mathrm{~mm}$ compr. prolongado abaixo das tecas, estames antepétalos ventralmente biauriculado, calcarado dorsalmente, estames ante-sépalos com aurículas e calcar fundidos formando uma bainha; ovário 3-locular, adnato ao hipanto na metade inferior, glabro; estilete ca. 3,5 mm compr., metade inferior creme, metade superior vináceo, reto, glabro, estigma truncado. Baga ca. 1,5×1,5 mm, atropurpúrea; sementes $0,7-1 \times 0,5 \mathrm{~mm}$, triangulares, superfície lisa.

Material examinado: Fazenda Paraíso, trilha para Casinha Branca, 'Escada de Pedras', 15.V.2003, fl., fr. e bot., R. Romero et al. 6893 (HUFU).

Material adicional examinado: BRASIL, MINAS GERAIS: Uberlândia, Clube Caça e Pesca Itororó, 11.V.2003, fr., A. A. A. Barbosa 33718 (HUFU).

Miconia chamissois ocorre do México até a Argentina e do norte ao sul do Brasil. Esta espécie é encontrada em campo úmido nas serras de Delfinópolis. Coletada com flores e frutos imaturos no mês de maio.

21. Miconia chartacea Triana, Trans. Linn. Soc. Bot. 28(1): 119. 1871.

Fig. 2 q

Árvores, 3-6 m alt. Ramos subcilíndricos, achatados no ápice. Indumento dos ramos e face abaxial das folhas densamente furfuráceo-dendrítico, do hipanto e lacínias do cálice lepidoto-dendrítico, face adaxial das folhas glabra. Folhas opostas, pecíolo 1,5-4,2 cm compr.; lâmina 9-25 ×3-7,5 cm, discolor, elíptica, ápice agudo a curto acuminado, base atenuada, margem inteira, 2 pares de nervuras acródromas, 3-10 mm compr. suprabasais. Panículas de glomérulos 8-28 cm compr., terminais. Flores 5-meras, sésseis; hipanto 33,5 × 1,5-2 mm, oblongo-campanulado; cálice com lacínias internas ca. 0,7 mm compr., triangulares, ápice agudo a arredondado, lacínias externas inconspícuas; pétalas 3-3,5 $\times 2 \mathrm{~mm}$, brancas, obovais, ápice retuso, assimétrico, margem não ciliada; estames 10 , iguais, creme, filetes 3-3,5 mm compr., glabros, anteras ca. 2,5 ×0,5 mm, oblongas, ápice truncado, uniporosas, poro diminuto, não inclinado ventralmente, conectivo ca. $0,3 \mathrm{~mm}$ compr. prolongado abaixo das tecas, espessado no dorso, calcar inconspícuo; ovário 2-3locular, adnato ao hipanto na metade inferior, glabro; estilete ca. 4 mm compr., creme, ápice 
róseo, filiforme, glabro, estigma truncado. Baga 2-5 × 2,5-5 mm, nigrescente; sementes ca. $1,5 \times 1 \mathrm{~mm}$, piramidais, superfície levemente sulcada.

Material examinado: Paraíso Selvagem, trilha para a cachoeira Salto Solitário, 4.XII.2002, fl. e bot., J.N. Nakajima et al. 3321 (HUFU); idem 11.III.2003, fr., J. N. Nakajima et al. 3463 (HUFU); Paraíso Selvagem, cachoeira do Alpinista, 16.V.2003, fr., $R$. A. Pacheco et al. 580 (HUFU); Paraíso Selvagem, 'Desertinho', 24.X.2003, bot., J. N. Nakajima et al. 3634 (HUFU); Fazenda do Sr. José Onório, estrada para 'Escada de Pedras', 29.XI.2003, bot., J. N. Nakajima et al. 3789 (HUFU).

Miconia chartacea ocorre somente no Brasil, nos estados do Rio Grande do Sul, Santa Catarina, São Paulo, Rio de Janeiro, Espírito Santo, Minas Gerais, Goiás, Bahia e no Distrito Federal. Nas serras de Delfinópolis ocorre em mata de galeria, mata ciliar e capão de mata em vertente de cachoeira. Coletada com flores nos meses de outubro, novembro e dezembro e com frutos nos meses de março e maio.

22. Miconia cubatanensis Hoehne, Anexos Mem. Inst. Butantan 1(5):139. 1922.

Arbustos, 1,5-1,8 m alt., arvoretas ou árvores, 2,5-6 $\mathrm{m}$ alt. Ramos jovens subcilíndricos, adultos cilíndricos, glabrescentes. Indumento dos ramos e face abaxial das folhas furfuráceo-dendrítico, do hipanto e lacínias do cálice lepidoto-dendrítico, com tricomas ocráceos, face adaxial das folhas com tricomas dendríticos a glabrescente. Folhas opostas, pecíolo 9-19 mm compr.; lâmina 5-12,5 × 1$2,6 \mathrm{~cm}$, discolor, lanceolada, raramente elíptica, ápice longo acuminado, raramente agudo, base atenuada a arredondada, margem inteira, levemente revoluta, 2 pares de nervuras acródromas basais a ca. $3 \mathrm{~mm}$ suprabasais, impressas na face adaxial, proeminentes e furfuráceo-dendríticas na face abaxial. Panículas escorpióides 4-8 cm compr., terminais. Flores 5-meras, sésseis; hipanto 22,5 ×2,5 mm, campanulado; cálice com lacínias ca. $1 \times 1,5 \mathrm{~mm}$, triangulares, ápice agudo a obtuso; pétalas 2,5-3,5 × 1,5 mm, brancas, oblongas a obovais, ápice assimetricamente arredondado, margem não ciliada; estames 10 , desiguais, creme, filetes 2,5-3 mm compr., glabros, anteras 1-2 1 mm, oblongas, ápice truncado, uniporosas, conectivo ca. 0,5 mm compr. prolongado abaixo das tecas, espessado dorsalmente, inapendiculado ventralmente, estames antepétalos com calcar dorsal ca. 0,3 mm compr., estames ante-sépalos com calcar pronunciado ca. 0,5 mm compr.; ovário 3locular, totalmente adnato ao hipanto, tricomas dendríticos no ápice; estilete 5-7 mm compr., creme, filiforme, glabro, estigma truncado. Baga 2,5-3,5×2-4 mm, atropurpúrea; sementes ca. $2 \times 1,5 \mathrm{~mm}$, curvas, superfície lisa.

Material examinado: Fazenda Paraíso, trilha para Casinha Branca, 'Escada de Pedras', 11.IV.2002, bot., R. A. Pacheco et al. 103 (HUFU); Paraíso Selvagem, cachoeira do Alpinista, 13.IV.2002, fr. e bot., $R$. $L$. Volpi et al. 141 (HUFU); Paraíso Selvagem, trilha para cachoeira Salto Solitário, 11.III.2003, fl. e bot., J. N. Nakajima et al. 3465 (HUFU); Fazenda Paraíso, trilha das cachoeiras, 13.III.2003, bot., $R$. Romero et al. 6747 (HUFU); Paraíso Selvagem, cachoeira do Alpinista, 16.V.2003, fl. e fr., R. A. Pacheco et al. 569 (HUFU); Fazenda Paraíso, estrada para Casinha Branca, 'Condomínio de Pedras', 17.V.2003, fl. e bt., R. L. Volpi et al. 667 (HUFU); Fazenda Paraíso, trilha das cachoeiras, 23.X.2003, fr., J. N. Nakajima et al. 3587 (HUFU); Paraíso Selvagem, cachoeira do Alpinista,15.IX.2004, fr., E. K. O. Hattori et al. 439 (HUFU).

Miconia cubatanensis é encontrada nos estados de Santa Catarina, Paraná, São Paulo, Rio de Janeiro, Espírito Santo, Minas Gerais, Mato Grosso, Goiás, Bahia e no Distrito Federal. Esta espécie é encontrada em mata de galeria, mata ciliar, mata mesófila semidecídua e, ocasionalmente, em campo rupestre nas serras de Delfinópolis. Coletada com floresde março a maio e com frutos em abril, maio, setembro e outubro.

23. Miconia elegans Cogn., in Mart. \& Eichler Fl. bras. 14(4): 312. 1888.

Árvores, 2-2,5 m alt. Ramos cilíndricos a subcilíndricos, ápice achatado. Indumento dos ramos furfuráceo-dendrítico, faces adaxial e abaxial das folhas e hipanto com tricomas dendríticos esparsos a glabrescentes. Folhas 
opostas, pecíolo 1,5-4 cm compr.; lâmina 14$30 \times 6,5-9,5 \mathrm{~cm}$, discolor, elíptica, oval ou lanceolada, ápice agudo ou acuminado, base atenuada, decurrente, margem inteira, 2 pares de nervuras acródromas, 5-10 mm compr. suprabasais, impressas na face adaxial, proeminentes na face abaxial. Panículas 13,5$18 \mathrm{~cm}$ compr., terminais. Flores 5-meras; pedicelo ca. $1 \mathrm{~mm}$ compr.; hipanto 2,5-3×2 $\mathrm{mm}$, oblongo, levemente urceolado; cálice com lacínias $0,7-1 \times 1,5 \mathrm{~mm}$, triangulares, ápice agudo; pétalas ca. $3 \times 2 \mathrm{~mm}$, brancas, ovais a obovais, ápice retuso a arredondado, margem não ciliada; estames 10 , desiguais, creme, filetes $2-3 \mathrm{~mm}$ compr., glabros, anteras 2,5-3 $\times 0,5 \mathrm{~mm}$, oblongas, ápice atenuado, uniporosas, conectivo ca. $0,3 \mathrm{~mm}$ compr. prolongado abaixo das tecas, inapendiculado ventralmente, estames antepétalos calcarado dorsalmente, estames ante-sépalos com uma projeção formando uma bainha dorsal; ovário 3-locular, adnato ao hipanto na metade inferior, glabro; estilete 4-4,5 mm compr., róseo, reto, glabro, estigma truncado. Baga 2-3 $\times 2,5-3 \mathrm{~mm}$, nigrescente; sementes $1,5-2 \times 1 \mathrm{~mm}$, curvas, superfície lisa.

Material examinado: Paraíso Selvagem, cachoeira do Alpinista, 15.IX.2004, fl. e bot., C. A. Faria et al. 77 (HUFU); idem, 15.IX.2004, fl., fr. e bot., E. K. O. Hattori et al. 430 (HUFU); idem, 15.IX.2004, fl., fr. e bot., J. N. Nakajima et al. 3863 (HUFU); idem, 15.IX.2004, fl., fr. e bot., R. Romero et al. 7117 (HUFU).

Miconia elegans ocorre no Brasil nos estados de São Paulo, Rio de Janeiro, Minas Gerais, Mato Grosso do Sul, Mato Grosso, Goiás, Bahia e no Distrito Federal. Nas serras de Delfinópolis, esta espécie ocorre em mata ciliar. Coletada com flores e frutos em setembro.

24. Miconia fallax DC., Prodromus 3:181. 1828.

Subarbustos ou arbustos, $0,8-1,5 \mathrm{~m}$ alt. Ramos quadrangulares a subquadrangulares. Indumento dos ramos, face abaxial das folhas e hipanto tomentoso, canescente, face adaxial das folhas glabra. Folhas opostas, pecíolo 2-5 mm compr.; lâmina 4,6-15,3 × 3-7 cm, discolor, oval a oval-lanceolada, ápice agudo a acuminado ou arredondado, base arredondada a subcordada, margem inteira a levemente crenulada, 2 pares de nervuras acródromas basais, nervuras impressas na face adaxial, proeminentes na face abaxial. Panículas de ramos escorpióides 7,5-18,5 cm compr., terminais. Flores 5-meras, sésseis; hipanto 33,5 x. 2,5 mm, campanulado; cálice com lacínias internas ca. $1 \times 1,5-2 \mathrm{~mm}$, triangulares, ápice agudo-acuminado, lacínias externas ca. 0,5 $\times$ $0,2 \mathrm{~mm}$, triangulares, ápice acuminado; pétalas 4-4,5 $\times 3-3,5 \mathrm{~mm}$, brancas, ovais a obovais, ápice arredondado, assimétrico, margem ciliado-glandulosa; estames 10, subiguais, creme, filetes 4-5 mm compr., glabros, anteras 3-3,5 $\times 1 \mathrm{~mm}$, oblongas, ápice atenuado, uniporosas, conectivo ca. $0,3 \mathrm{~mm}$ compr. prolongado abaixo das tecas, espessado no dorso, apêndice bilobado ventralmente, tuberculado dorsalmente; ovário 3-locular, adnato ao hipanto na metade inferior, glabro; estilete 8,5-9 mm compr., amarelo, reto, glabro, estigma truncado. Baga ca. $3 \times 3,5 \mathrm{~mm}$, atropurpúrea a nigrescente; sementes ca. $1 \times$ 0,5-1 mm, piramidais, superfície lisa.

Material examinado: Fazenda Paraíso, trilha para Casinha Branca, 'Escada de Pedras', 11.X.2002, fr., R. Romero et al. 6411 (HUFU); estrada para a Gurita, 21.X.2003, fl. e bot., J. N. Nakajima et al. 3531 (HUFU); Paraíso Selvagem, trilha para mata do Canyon, 22.X.2003, fl. e bot., J. N. Nakajima et al. 3539 (HUFU); idem, 22.X.2003, fl. e bot., J. N. Nakajima et al. 3577 (HUFU); Fazenda Paraíso, trilha das cachoeiras, 23.X.2003, fl. e fr., J. N. Nakajima et al. 3606 (HUFU); Fazenda Paraíso, estrada para Casinha Branca, 'Condomínio de Pedras', 25.X.2003, fl. e fr., J. N. Nakajima et al. 3697 (HUFU); Fazenda Paraíso, trilha para Casinha Branca, 'Escada de Pedras', 14.IX.2004, bt., C. A. Faria et al. 44 (HUFU); idem, 14.IX.2004, fl., fr. e bot., E. K. O. Hattori et al. 362 (HUFU); idem, 14.IX.2004, fl., fr. e bot., J. N. Nakajima et al. 3843 (HUFU); Estrada para a Gurita, 8.XI.2005, fr., $R$. Romero et al. 7282 (HUFU); Fazenda Paraíso, trilha para Casinha Branca, 'Escada de Pedras', 9.XI.2005, fr., R. Romero et al. 7288 (HUFU); idem, 9.XI.2005, fr., R. Romero et al. 7301 (HUFU). 
Miconia fallax ocorre da Venezuela ao Paraguai e no Brasil é encontrada nos estados de São Paulo, Minas Gerais, Mato Grosso, Goiás, Bahia, Pará, Rondônia, Roraima e no Distrito Federal. Encontrada em campo rupestre, cerrado rupestre e cerrado das serras de Delfinópolis. Coletada com flores em setembro e outubro e com frutos de setembro a novembro.

\section{Miconia ferruginata DC., Prodromus} 3:181. 1828 .

Arvoretas ou árvores, 2-4 m alt. Ramos cilíndricos a subcilíndricos. Indumento dos ramos e hipanto densamente tomentoso-dendrítico, ocráceos, faces adaxial e abaxial das folhas revestidas de tricomas dendríticos, face adaxial glabrescente, face abaxial canescente. Folhas opostas, pecíolo 2-6 cm compr., estriado; lâmina 11-24,5 ×5,5-14 cm, discolor, elíptica, oval a oboval, ápice agudo a acuminado, raramente arredondado, base arredondada a atenuada, raramente subcordada ou assimétrica, margem inteira, levemente ondulada, 3 pares de nervuras acródromas basais, par marginal inconspícuo, impressas na face adaxial, proeminentes na face abaxial. Panículas de ramos escorpióides 12-29 cm compr., terminais. Flores 5-meras, sésseis; hipanto ca. $5 \times 4 \mathrm{~mm}$, oblongo a levemente campanulado; cálice com lacínias ca. $0,7 \times 1 \mathrm{~mm}$, triangulares, ápice agudo, fundidas, persistentes; pétalas ca. $5 \times$ $2,5 \mathrm{~mm}$, brancas, obovais, ápice retuso, margem não ciliada; estames 10, subiguais, creme, filetes 3,5-4 $\mathrm{mm}$ compr., glabros, anteras 2-2,5 ×0,5 mm, subuladas, ápice atenuado, uniporosas, conectivo $0,5-0,7 \mathrm{~mm}$ compr. prolongado abaixo das tecas, espessado dorsalmente, biauriculado ventralmente, dorsalmente expandido na base; ovário 3locular, adnato ao hipanto na metade inferior, glabro; estilete ca. 8,5 mm compr., creme, filiforme, glabro, estigma truncado. Baga 35,5 $\times 4-5,5 \mathrm{~mm}$, nigrescente; sementes ca. 2 $\times 1 \mathrm{~mm}$, piramidais, superfície lisa.

Material examinado: Fazenda Paraíso, estrada para Casinha Branca, 'Condomínio de Pedras', 10.IV.2002, fr. e bot., R. Romero et al. 6340 (HUFU); idem, 17.V.2003, fl., fr. e bot., R. L. Volpi et al. 697 (HUFU);
Fazenda Paraíso, trilha para Casinha Branca, 'Escada de Pedras', 14.IX.2004, fr., E. K. O. Hattori et al. 412 (HUFU); estrada para a Gurita, 8.XI.2005, fr., R. Romero et al. 7281 (HUFU).

Miconia ferruginata ocorre no Brasil, nos estados de São Paulo, Minas Gerais, Mato Grosso do Sul, Mato Grosso, Goiás, Bahia, Pará e no Distrito Federal. Nas serras de Delfinópolis ocorre em campo rupestre e, ocasionalmente, no cerrado rupestre. Foram coletados espécimes com flores em abril e maio e com frutos em abril, maio, setembro e novembro.

26. Miconia ibaguensis (Bonpl.) Triana, Trans. Linn. Soc. Bot. 28(1): 110. 1871.

Arbustos, 1,5-1,8 m alt. Ramos cilíndricos, decorticantes para a base. Indumento dos ramos, face adaxial das folhas e hipanto híspido, entremeado com tricomas dendríticos, da face abaxial das folhas viloso. Folhas opostas, pecíolo 4-7 mm compr.; lâmina 7,6-11,4×2,5$4,3 \mathrm{~cm}$, discolor, oval-lanceolada, ápice agudo a acuminado, base arredondada, margem serreada, ciliada, 2 pares de nervuras acródromas, 3-5 mm compr. suprabasais, moderadamente vilosas. Panículas de glomérulos $3-8 \mathrm{~cm}$ compr., terminais. Flores 5-meras, sésseis; hipanto 2,5-3×2-2,5 mm, campanulado; cálice com lacínias ca. $0,5 \times 1 \mathrm{~mm}$, triangulares, ápice agudo-apiculado; pétalas ca. $2 \times 2,5 \mathrm{~mm}$, brancas, obovais, ápice arredondado, margem ciliada no ápice; estames 10, subiguais, creme, filetes 2-3 mm compr., glabros, anteras ca. 2 $\times$ ca. 0,3 mm, oblongas, ápice atenuado, uniporosas, conectivo ca. $0,5 \mathrm{~mm}$ compr. prolongado abaixo das tecas, espessado no dorso, biauriculado ventralmente; ovário 3locular, adnato ao hipanto na metade inferior, glabro; estilete ca. $3 \mathrm{~mm}$ compr., creme, reto, glabro, estigma capitado. Baga 2,5-3 × 3-4 $\mathrm{mm}$, nigrescente; sementes ca. $1 \times 0,5 \mathrm{~mm}$, piramidais, superfície lisa.

Material examinado: Estrada para a Gurita, 21.X.2003, fl. e bot., J. N. Nakajima et al. 3525 (HUFU); Fazenda Paraíso, trilha para Casinha Branca, 'Escada de Pedras', 26.XI.2003, fr. e bot., $R$. Romero et al. 6987 (HUFU); estrada para a Gurita, 8.XI.2005, fr., R. Romero et al. 7278 (HUFU). 
Miconia ibaguensis ocorre desde o sul do México ao Paraguai e no Brasil, nos estados do Paraná, São Paulo, Rio de Janeiro, Espírito Santo, Minas Gerais, Mato Grosso, Goiás e Bahia. Nas serras de Delfinópolis esta espécie ocorre em borda de mata de galeria, borda de mata mesófila semidecídua e na beira de cursos d'água. Coletada com flores em outubro e novembro e com frutos em novembro.

27. Miconia ligustroides (DC.) Naudin, Ann. Sci. Nat., Ser. 3, Bot. 16:167. 1851.

Arbustos, ca. 1,5 m alt. Ramos cilíndricos, decorticantes. Indumento dos ramos furfuráceo-dendrítico, ferrugíneo, glabrescente, das faces adaxial e abaxial das folhas e hipanto piloso-dendrítico, tricomas esparsos. Folhas opostas, pecíolo 4-6 mm compr.; lâmina 4,5$8,5 \times 1,8-3 \mathrm{~cm}$, discolor, elíptica, raramente oboval, ápice agudo-acuminado, raramente arredondado, base arredondada, margem inteira, levemente ondulada e revoluta, 2 pares de nervuras acródromas basais, par marginal tênue. Panículas 5-8 cm compr., terminais. Flores 5-meras, subsésseis; hipanto ca. $2 \times 1,5$ $\mathrm{mm}$, oblongo-campanulado; cálice com lacínias $0,2-0,5 \times 0,5-0,7 \mathrm{~mm}$, ápice agudo; pétalas 2,5-3,5 $\times 2 \mathrm{~mm}$, brancas, obovais, ápice arredondado, assimétrico, margem não ciliada; estames 10, desiguais, creme, filetes $2-2,5 \mathrm{~mm}$ compr., glabros, anteras ca. $2 \times 0,5 \mathrm{~mm}$, oblongas, ápice truncado, uniporosas, conectivo ca. 0,2 $\mathrm{mm}$ compr. prolongado abaixo das tecas, nos estames antepétalos curto bilobado ventralmente, expandido dorsalmente, conectivo dos estames ante-sépalos calcarado no dorso; ovário 3-locular, adnato ao hipanto na metade inferior, glabro; estilete ca. $4 \mathrm{~mm}$ compr., creme com ápice vináceo, reto, glabro, estigma truncado. Baga 1,5-2 × 1,5-2 mm, nigrescente; sementes ca. $1 \times 0,5 \mathrm{~mm}$, piramidais, superfície lisa.

Material examinado: Estrada para a Gurita, 3.XII.2002, fr. e bot., R. L.Volpi et al. 313 (HUFU).

Miconia ligustroides ocorre nos estados de Santa Catarina, Paraná, São Paulo, Rio de Janeiro, Espírito Santo, Minas Gerais, Mato Grosso, Goiás, Bahia e Ceará. Nas serras de
Delfinópolis ocorre em borda de capão de mata. Coletada com flores e frutos em dezembro.

28. Miconia minutiflora (Bonpl.) DC., Prodromus 3:189. 1828. Fig. $2 \mathrm{r}$ Árvores, ca. $5 \mathrm{~m}$ alt. Ramos subcilíndricos, sulcados, nigrescentes, glabrescentes. Indumento dos ramos e faces adaxial e abaxial das folhas piloso-dendrítico, tricomas esparsos, mais densos nos sulcos e nas nervuras, hipanto glabro. Folhas opostas, pecíolo 6-10 mm compr.; lâmina 8-14 $\times 2,2-3,4 \mathrm{~cm}$, discolor, oval-lanceolada, ápice longo acuminado, base atenuada, margem inteira a levemente ondulada, 2 pares de nervuras acródromas basais, par marginal tênue. Panículas 5,5-8,5 cm compr., terminais e laterais. Flores 5-meras, sésseis; hipanto ca. 1 $\times 1-1,5 \mathrm{~mm}$, campanulado; cálice com lacínias ca. $1 \times 1,5 \mathrm{~mm}$, triangulares, ápice agudo, margem recortada; pétalas 1,5-2 $\times 1-1,5 \mathrm{~mm}$, brancas, ovais a obovais, ápice agudo a arredondado, margem não ciliada; estames 10, subiguais, creme, filetes $1-1,5 \mathrm{~mm}$ compr., glabros, anteras 1-1,5 ×0,3 mm, oblongas, uniporosas, poro amplo, ventralmente inclinado, conectivo $0,3-0,5 \mathrm{~mm}$ compr. prolongado abaixo das tecas, nos estames antepétalos e antesépalos com calcar dorsal ca. 0,3 mm compr., expandido; ovário 4-locular, adnato ao hipanto na metade inferior, glabro; estilete $2,5-3 \mathrm{~mm}$ compr., amarelo, reto, glabro, estigma truncado. Baga ca. $3 \times 2,5-3 \mathrm{~mm}$, nigrescente; sementes ca. $0,7 \times 0,5 \mathrm{~mm}$, piramidais, superfície lisa.

Material examinado: Estrada próxima ao rio Santo Antônio, 12.IV.2002, fr., J. N. Nakajima et al. 3141 (HUFU).

Material adicional examinado: BRASIL, MINAS GERAIS: Uberlândia, vale do Rio Araguari, 27.II.1991, fl. e bot., A. L. P. Mota 118 (HUFU).

Miconia minutiflora ocorre do sul do México e Caribe ao Sudeste do Brasil. Encontrada nas serras de Delfinópolis somente em mata mesófila semidecídua. Coletada com frutos no mês de abril.

29. Miconia pepericarpa DC., Prodromus 3:182. 1828.

Arvoretas ou árvores, 1,5-4 m alt. Ramos jovens subcilíndricos, mais velhos cilíndricos, 
decorticantes para a base. Indumento dos ramos, faces adaxial e abaxial das folhas e hipanto piloso-dendrítico, com tricomas dendríticos curtos, ocráceos, denso. Folhas opostas, pecíolo 89(18) mm compr.; lâmina 5,5-13,5 ×1-2,3 cm, discolor, lanceolada, raramente oval-lanceolada, ápice acuminado, raro agudo, base arredondada, raramente atenuada ou assimétrica, margem inteira, levemente revoluta, 2 pares de nervuras acródromas, 1-4 mm compr. suprabasais, impressas na face adaxial, proeminentes na face abaxial. Panículas de glomérulos 2,5-7,5 $\mathrm{cm}$ compr., terminais e laterais. Flores 4meras, sésseis; hipanto ca. 1,5 × $1 \mathrm{~mm}$, oblongo; cálice com lacínias internas ca. 0,3× 1-1,5 mm, triangulares, ápice retuso, lacínias externas linear-triangulares, ápice agudoapiculado; pétalas $1-1,5 \times 0,7-0,8 \mathrm{~mm}$, brancas, oval-oblongas, ápice retuso, margem não ciliada; estames 8 , iguais, creme, filetes ca. $2 \mathrm{~mm}$ compr., glabros, anteras ca. $2 \times 0,5$ $\mathrm{mm}$, oblongas, uniporosas, poro ventralmente inclinado, conectivo ca. 0,5 mm compr. prolongado abaixo das tecas, inapendiculado; ovário 3-locular, tricomas dendríticos esparsos no ápice; estilete 1,7-2 mm compr., creme, reto, glabro, estigma punctiforme. Baga ca. 2 $\times 1,5-2 \mathrm{~mm}$, nigrescente; sementes ca. $2 \times$ 1,5 mm, ovais, superfície lisa.

Material examinado: Fazenda Paraíso, estrada para Casinha Branca, 'Condomínio de Pedras', 10.IV.2002, fr., J. N. Nakajima et al. 6336 (HUFU); Paraíso Selvagem, trilha para cachoeira Salto Solitário, 4.XII.2002, fl. e bot., J. N. Nakajima et al.3323 (HUFU); Fazenda Paraíso, trilha para Casinha Branca, 'Escada de Pedras', 5.XII.2002, fl.e bot., R. L. Volpi et al. 346 (HUFU); Fazenda do Sr. José Onório, estrada para 'Escada de Pedras', 26.XI.2003, fl. e bot., R. Romero et al. 6989 (HUFU); Fazenda Paraíso, trilha para Casinha Branca, 'Escada de Pedras', 9.XI.2005, fl. e bot., R. Romero et al. 7292 (HUFU).

Miconia pepericarpa ocorre em áreas de cerrado de São Paulo, Minas Gerais, Goiás, Bahia e Distrito Federal. Nas serras de Delfinópolis esta espécie é encontrada em campo rupestre, cerrado rupestre, borda de capão de mata e de mata de galeria. Coletada com flores em novembro e dezembro e com frutos em abril.
30. Miconia pseudonervosa Cogn., in Mart. \& Eichler Fl. bras. 14(4)337. 1888.

Arbustos, arvoretas ou árvores, 1,7-3 m alt. Ramos jovens subcilíndricos, adultos cilíndricos. Indumento dos ramos e hipanto adpresso-setoso, da face adaxial das folhas moderadamente estrigoso, da face abaxial setoso-viloso. Folhas opostas, pecíolo 2,2-7 cm compr.; lâmina 11,5-25×6,5-11,5 cm, discolor, oval, raramente oboval, ápice acuminado, base atenuado-arredondada, raramente assimétrica, margem denteada, ciliada, 3-4 pares de nervuras acródromas, 2-7 cm compr. suprabasais, nervuras impressas na face adaxial, proeminentes na face abaxial. Panículas de glomérulos 5-15 cm compr., terminais. Flores 5-meras, sésseis ou subsésseis; hipanto 3,5-4×2,5-3 mm, oblongo; cálice com lacínias internas ca. $0,7 \times 1,5 \mathrm{~mm}$, triangulares, ápice arredondado, lacínias externas triangulares, ápice longo-apiculado; pétalas 3,5-5 × 1,5-2 mm, brancas, oblongas, ápice arredondado, margem não ciliada; estames 10, desiguais, cremes, filetes 3-4 mm compr., glabros, anteras 3-4 × $0,5 \mathrm{~mm}$, oblongas, ápice truncado, uniporosas, poro diminuto, não inclinado ventralmente, conectivo ca. 0,5 mm compr. prolongado abaixo das tecas, conectivo dos estames antepétalos curto tuberculado dorsalmente, conectivo dos estames ante-sépalos bituberculado dorsalmente; ovário 3-locular, adnato ao hipanto nos três quartos inferiores, adpressosetoso no ápice; estilete 7,5-9 mm compr., creme, reto, glabro, estigma punctiforme. Baga 3-4 × 3-4 mm, atropurpúrea; sementes ca. 1 $\times 0,5 \mathrm{~mm}$, piramidais, superfície lisa.

Material examinado: Fazenda Maria Concebida, cachoeira do rio Águas Claras, 12.IV.2002, fl., fr. e bot., J. N. Nakajima et al. 3123 (HUFU); Paraíso Selvagem, cachoeira do Alpinista, 10.X.2002, fl. e bot., R. A. Pacheco et al. 218 (HUFU); Paraíso Selvagem, 'Desertinho', 24.X.2003, fl. e fr., $R$. A. Pacheco et al. 691 (HUFU); Fazenda do Sr. José Onório, estrada para 'Escada de Pedras', 29.XI.2003, fr. e bot., J. N. Nakajima et al. 3769 (HUFU); Paraíso Selvagem, cachoeira do Alpinista, 15.IX.2004, fl. e bot., C.A. Faria et al. 82 (HUFU); idem, 15.IX.2004, fl. e bot., E. K. O. Hattori et al. 433 (HUFU); idem, 
15.IX.2004, bot., J. N. Nakajima et al. 3864 (HUFU); idem, 15.IX.2004, fl. e bot., R. Romero et al. 7119 (HUFU); idem, 10.XI.2005, fl., fr. e bot., R. Romero et al. 7303 (HUFU).

Miconia pseudonervosa ocorre em São Paulo, Minas Gerais, Rio de janeiro, Goiás e Distrito Federal. Nas serras de Delfinópolis é encontrada em mata de galeria e mata ciliar. Coletada com flores em abril e de setembro a novembro, e com frutos em abril, outubro e novembro.

\section{Miconia rubiginosa (Bonpl.) DC., Prodromus 3:183.1828. Fig. $2 \mathrm{~s}-\mathrm{t}$}

Arbustos, arvoretas ou árvores, 1,5-3 m alt. Ramos cilíndricos, subcilíndricos no ápice. Indumento dos ramos, face adaxial e abaxial das folhas, nervuras e hipanto moderadamente a densamente setoso-dendrítico, tricomas ferrugíneos. Folhas opostas, pecíolo 5-9 mm compr.; lâmina 7,2-12 × 3-5,7 cm, discolor, elíptica a oval-lanceolada, ápice agudoacuminado, base arredondada a subcordada, margem inteira, ciliada, levemente revoluta, 2 pares de nervuras acródromas basais, par marginal tênue, impressas na face adaxial, proeminentes na face abaxial. Panículas 10,5$18 \mathrm{~cm}$ compr., terminais. Flores 5-meras, sésseis; hipanto ca. $2 \times 1,5 \mathrm{~mm}$, oblongo; cálice com lacínias internas $1-2 \times 1-1,5 \mathrm{~mm}$, triangulares, ápice agudo, lacínias externas, triangulares, ápice apiculado; pétalas 2-3 × 1,5-2 $\mathrm{mm}$, brancas, obovais, ápice arredondado, margem ciliadoglandulosa no ápice; estames 10, desiguais, creme, filetes 1,5-2 mm compr., glabros, anteras 1,5-2 $\times 0,5 \mathrm{~mm}$, oblongas, ápice atenuado, uniporosas, conectivo ca. $0,2 \mathrm{~mm}$ compr. prolongado abaixo das tecas, apêndice ventral biauriculado, conectivo dos estames antepétalos calcarado dorsalmente, glabro, conectivo dos estames antesépalos expandido dorsalmente, glabro; ovário 3locular, adnato ao hipanto na metade inferior, glabro; estilete 4-4,5 mm compr., creme, ápice arroxeado, reto, glabro, estigma truncado. Baga 3-4 × 2,5-3,5 mm, atropurpúrea; sementes 11,5 $\times 0,5-1 \mathrm{~mm}$, piramidais, superfície lisa.

Material examinado: Estrada para a Gurita, 7.X.2002, fl. e bot., R. Romero et al. 6369 (HUFU); Serra do
Cemitério, trilha do Zé Carlinho, 9.X.2002, fl. e bot., J. N. Nakajima et al. 3218 (HUFU); estrada para a Gurita, 03.XII.2002, bot., R.L. Volpi et al. 291 (HUFU); Paraíso Selvagem, trilha para cachoeira Salto Solitário, 4.XII.2002, fr. e bot., J. N. Nakajima et al. 3330 (HUFU); Fazenda Paraíso, estrada para Casinha Branca, 'Condomínio de Pedras', 12.III.2003, fr., R.L. Volpi et al. 545 (HUFU); Fazenda do Sr. José Onório, estrada para 'Escada de Pedras', 23.X.2003, bot., J. N. Nakajima et al. 3609 (HUFU); idem, 26.XI.2003, bot., R. Romero et al. 6746 (HUFU); Fazenda Paraíso, trilha para Casinha Branca, 'Escada de Pedras', 9.XI.2005, fl. e bot., R. Romero et al. 7285 (HUFU); idem, 9.XI.2005, fl. e bot., $R$. Romero et al. 7296 (HUFU).

Miconia rubiginosa ocorre da Costa Rica à Bolívia, e no Cerrado dos estados brasileiros de São Paulo, Minas Gerais, Mato Grosso, Goiás, Bahia, Pará, Amazonas, Rondônia e Roraima. Nas serras de Delfinópolis é encontrada em campo rupestre, cerrado rupestre, borda e interior de mata mesófila semidecídua, capão de mata em vertente de cachoeira e mata de galeria. Exemplares foram coletados com flores em março e de outubro a dezembro, e com frutos em março, novembro e dezembro.

32. Miconia sellowiana Naudin, Ann. Sci. Nat., Ser. 3, Bot. 16:206. 1851. Fig. 2 u Árvores, ca. $3 \mathrm{~m}$ alt. Ramos cilíndricos, decorticantes para a base. Indumento dos ramos, face abaxial das folhas, nervuras e hipanto moderadamente piloso-dendrítico, face adaxial das folhas glabra. Folhas opostas, pecíolo 1-1,5 cm compr.; lâmina 8,5-13 × 2$3,5 \mathrm{~cm}$, discolor, lanceolada, ápice longo acuminado, base atenuada, levemente decurrente no pecíolo, margem serreada, 2 pares de nervuras acródromas, 3-5 mm compr. suprabasais, impressas na face adaxial, proeminentes na face abaxial, domáceas foliares presente. Panículas 2-8 cm compr., terminais. Flores 5-meras, sésseis ou subsésseis; hipanto ca. $2 \times 2 \mathrm{~mm}$, campanulado; cálice com lacínias internas ca. 0,3 $\times 0,5-0,7 \mathrm{~mm}$, triangulares, ápice arredondado, lacínias externas triangulares, ápice agudo; pétalas 1,5-2×1-1,5 mm, brancas, obovais, ápice arredondado, margem não ciliada; estames 10, subiguais, creme, filetes $1,5-2 \mathrm{~mm}$ compr., glabros, anteras $1,5-2 \times 0,5 \mathrm{~mm}$, oblongas, 
uniporosas, poro amplo, inclinado ventralmente, conectivo ca. $0,5 \mathrm{~mm}$ compr. prolongado abaixo das tecas, inapendiculado a curto bilobado ventralmente; ovário 3-locular, adnato ao hipanto na metade inferior, glabro; estilete ca. $3 \mathrm{~mm}$, creme, reto, glabro, estigma truncado. Baga 2-3 $\times 2,5 \mathrm{~mm}$, atropurpúrea; sementes ca. 1,5 × 1 $\mathrm{mm}$, piramidais, superfície lisa.

Material examinado: Paraíso Selvagem, trilha para mata do Canyon, 22.X.2003, fl. e bot., J. N. Nakajima et al. 3564 (HUFU); idem, 22.X.2003, fl., J. N. Nakajima et al. 3567 (HUFU); Paraíso Selvagem, trilha para Salto do Canyon, 27.XI.2003, fr., $R$. A. Pacheco et al. 709 (HUFU).

Miconia sellowiana ocorre nos estados do Rio Grande do Sul, Santa Catarina, Paraná, São Paulo, Rio de Janeiro, Minas Gerais, Goiás e no Distrito Federal. Nas serras de Delfinópolis esta espécie é encontrada em mata mesófila semidecídua e mata de galeria. Coletada com botões florais e flores em outubro e com frutos em novembro.

33. Miconia theaezans (Bonpl.) Cogn., in Mart. \& Eichler Fl. bras. 14(4): 419. 1888.

Fig. 2 v

Arvoretas, ca. $3 \mathrm{~m}$ alt. Ramos subcilíndricos a cilíndricos. Ramos, faces adaxial e abaxial das folhas e hipanto glabros. Folhas opostas, pecíolo 1-2,2 cm compr.; lâmina 4,8-10 ×2,5-3 cm, discolor, elíptica a oboval, ápice agudo a curto acuminado, base arredondada, margem serreada, 2 pares de nervuras acródromas basais, par marginal tênue, nervuras impressas na face adaxial, proeminentes na face abaxial. Panículas 8-16 cm compr., terminais. Flores 5-meras; pedicelo ca. $0,5 \mathrm{~mm}$ compr.; hipanto $1-1,5 \times 1,5 \mathrm{~mm}$, campanulado; cálice com lacínias internas ca. 0,5 × 1-1,5 mm, triangulares, ápice agudo a arredondado, lacínias externas triangulares, ápice agudo; pétalas 1-1,5 × $1 \mathrm{~mm}$, brancas, obovais, ápice arredondado, margem não ciliada; estames 10, iguais, creme, filetes ca. 2 mm compr., glabros, anteras ca. $1 \times 0,5 \mathrm{~mm}$, oblongas, ápice truncado, 4-porosas, conectivo ca. 0,2 mm compr., prolongado abaixo das tecas, espessado no dorso, bituberculado ventralmente; ovário 2-locular, adnato ao hipanto na metade inferior, glabro; estilete ca. $3 \mathrm{~mm}$ compr., creme, reto, glabro, estigma truncado. Baga 1-2 × 1-2 mm, atropupúrea, sementes ca. $0,5 \times 0,2 \mathrm{~mm}$, curvas, superfície tuberculada.

Material examinado: Fazenda Paraíso, trilha das cachoeiras, 29.XI.2003, fl., fr. e bot., J. N. Nakajima et al. 3803 (HUFU).

Miconia theaezans é amplamente distribuída no Neotrópico, ocorrendo desde a América Central até o estado de Santa Catarina. Nas serras de Delfinópolis esta espécie ocorre em campo rupestre, próximo a cursos d'água. Coletada com botões florais, flores e frutos em novembro.

34. Microlicia canastrensis Naudin, Ann. Sci. Nat., Ser. 3, Bot. 3:174: 1845. Fig. 3 a-c

Subarbustos, 0,3-1 m alt. Ramos jovens quadrangulares, adultos subcilíndricos a cilíndricos, glabrescentes. Indumento dos ramos, faces adaxial e abaxial das folhas, hipanto e lacínias do cálice glutinoso, tricomas glandulares sésseis e pedicelados. Folhas opostas, sésseis; lâmina 6-15×2-7 mm, concolor, oval-oblonga, ápice agudo, curto-apiculado, base arredondada, margem inteira, ciliado-glandulosa, 1 par de nervuras acródromas basais, nervura central proeminente na face abaxial. Flores 5-meras, solitárias, terminais e axilares; pedicelo ca. 2 mm compr.; hipanto 3-3,5×1,5-2 mm, oblongo; lacínias do cálice 3,5-5,5 mm compr., longo triangulares, ápice agudo, longo-apiculado; pétalas 8-13 × 4-7,5 mm, púrpuras, obovaloblongas, ápice agudo a acuminado, margem não ciliada; estames 10, desiguais, filetes 5-5,5 $\mathrm{mm}$, purpúreos, glabros, anteras $2-3 \times 0,5 \mathrm{~mm}$, amarelas, rostro 0,5-1 mm compr., oblongas, uniporosas, estames antepétalos com conectivo ca. $1 \mathrm{~mm}$ compr., prolongado abaixo das tecas, amarelo ou púrpura, apêndice ventral ca. 0,5 mm compr., amarelo, expandido; estames antesépalos com conectivo 2-3 mm compr., apêndice ventral 1-1,5 mm compr., amarelo, obtuso; ovário 3-locular, livre, glabro; estilete 66,5 mm compr., púrpura, filiforme, curvo no ápice, glabro; estigma truncado. Cápsula, 4-5×3 mm, 


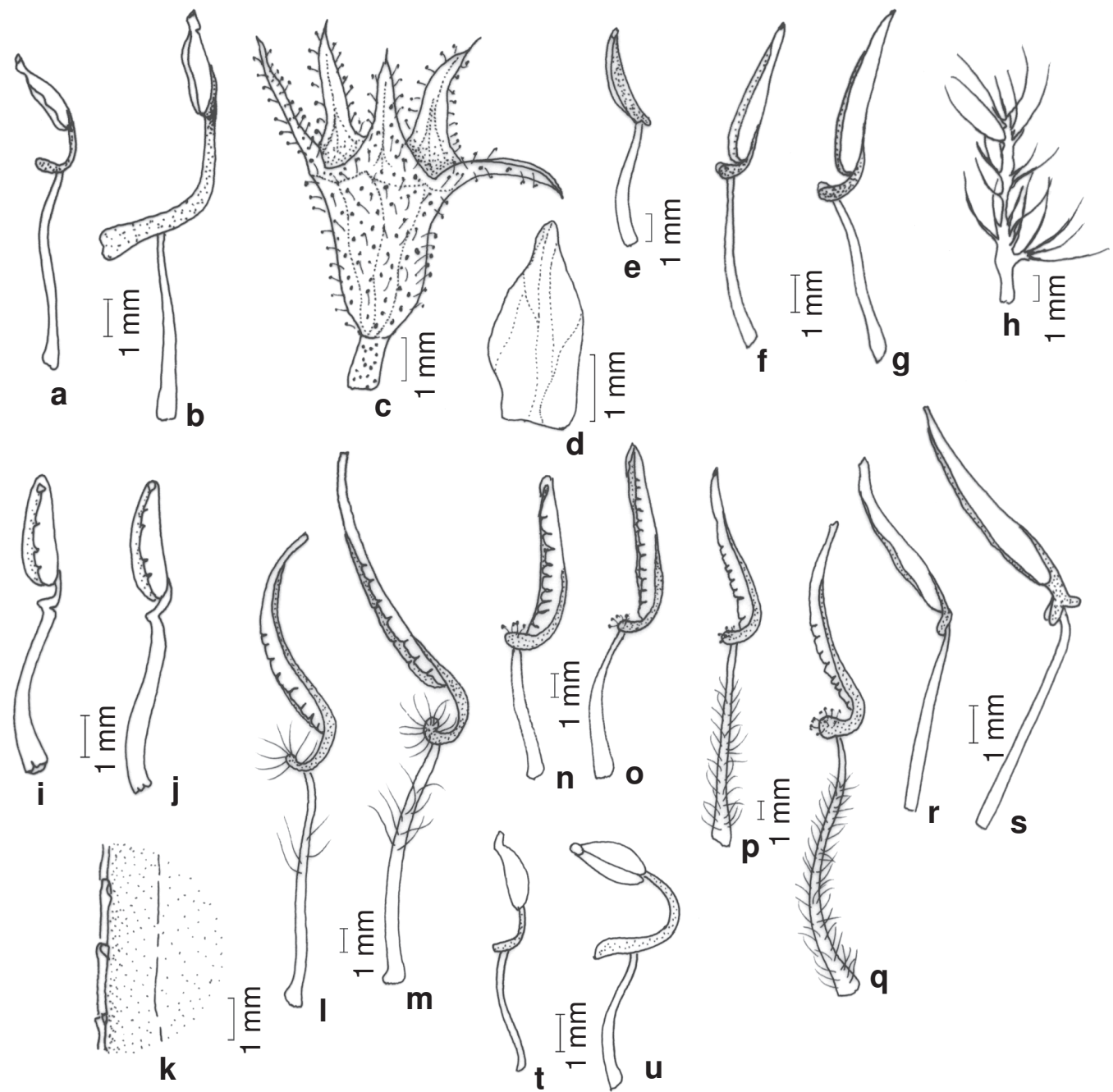

Figura 3 - a-c. Microlicia canastrensis - a. estame antepétalo; b. estame ante-sépalo; c. hipanto (Romero 6234). d-e. Ossaea congestiflora -d. pétala; e. estame (Nakajima 3364). f-h. Pterolepis repanda -f. estame antepétalo; g. estame ante-sépalo; h. tricoma penicilado (Romero2280). i-k. Svitramia integerrima - i. estame antepétalo; j. estame ante-sépalo; k. detalhe da margem da lâmina foliar (Romero 6853). 1-m. Tibouchina aegopogon - 1. estame antepétalo; m. estame ante-sépalo (Volpi 327). n-o. T. bergiana - n. estame antepétalo; o. estame ante-sépalo (Romero 6750). p-q. T. candolleana - p. estame antepétalo; q. estame ante-sépalo (Hattori 391). r-s. T. gracilis - r. estame antepétalo; s. estame ante-sépalo (Nakajima 3352). t-u. Trembleya phlogiformis - t. estame antepétalo; u. estame ante-sépalo (Pacheco 138).

castanha; sementes ca. $0,7 \times 0,5 \mathrm{~mm}$, curvas, superfície papilosa.

Material examinado: Fazenda Paraíso, estrada para Casinha Branca, 'Condomínio de Pedras', 10.IV.2002, fl., fr. e bot., $R$. Romero et al. 6323 (HUFU); idem, 10.IV.2002, fl., fr. e bot., $R$. Romero et al. 6234 (HUFU); Fazenda Paraíso, trilha para Casinha Branca, 'Escada de Pedras', 11.X.2002, fl., fr. e bot., $R$. Romero et al. 6448(HUFU); idem, 5.XII.2002, fl., fr. e bot., R. L. Volpi et al. 379 (HUFU); estrada para a Gurita, 9.III.2003, fl., fr. e bot., J. N. Nakajima et al. 3439 (HUFU);
Fazenda Paraíso, trilha para Casinha Branca, 'Escada de Pedras', 10.III.2003, fl., fr. e bot., R. L. Volpi et al. 542 (HUFU); Fazenda Paraíso, estrada para Casinha Branca, 'Condomínio de Pedras', 12.III.2003, fl. e bot., R. L. Volpi et al. 586 (HUFU); idem, 17.V.2003, fl., fr. e bot., $R$. A. Pacheco et al. 604 (HUFU); Fazenda Paraíso, trilha para Casinha Branca, 'Escada de Pedras', 9.XI.2005, fl., fr. e bot., R. Romero et al. 7294 (HUFU).

Microlicia canastrensis ocorre somente no sudoeste e noroeste do estado de Minas Gerais. Nas serras de Delfinópolis é encontrada em 
campo rupestre e, ocasionalmente, em cerrado rupestre. Coletada com botões, flores e frutos de março a maio e de outubro a dezembro.

35. Microlicia euphorbioides Mart., Nov. Gen. Sp. Pl. 3:107. 1831.

Subarbustos, 0,3-1 m alt. Caule cilíndrico, glabrescente, decorticante e áfilo para a base, ramos quadrangulares. Indumento dos ramos, faces adaxial e abaxial das folhas, hipanto e lacínias do cálice hirsuto, e com tricomas glandulares sésseis. Folhas opostas, pecíolo 0,5-1 mm compr.; lâmina 5-20 × 2-7 mm, concolor, elíptica, ápice agudo, curto-apiculado, base atenuada a arredondada, margem crenulada, ciliada, 1-2 pares de nervuras acródromas, 0,5-1,5 mm compr. suprabasais. Flores 5-meras, solitárias, terminais ou axilares; pedicelo 1,5-2,5 mm compr.; hipanto 3-3,5× 1,5 mm, oblongo, suburceolado; lacínias do cálice 2-3 ×0,5-1 mm, triangular-lanceoladas, ápice agudo, longo-apiculado; pétalas 4-6 $\times$ 2-3 mm, brancas ou róseas, oboval-oblongas, ápice agudo, curto-apiculado, margem não ciliada; estames 10, desiguais, amarelos; estames antepétalos com filetes $2-3 \mathrm{~mm}$ compr., glabros, anteras $1-1,5 \times 0,5 \mathrm{~mm}$, rostro 0,3-0,5 mm compr., oblongas, uniporosas, conectivo 1-1,5 mm compr., prolongado abaixo das tecas, apêndice ventral ca. $0,5 \mathrm{~mm}$ compr.; estames ante-sépalos com filetes $3-4 \mathrm{~mm}$ compr., glabros, anteras ca. $1,5 \times 0,5 \mathrm{~mm}$, rostro $0,3-0,5 \mathrm{~mm}$ compr., oblongas, uniporosas, conectivo $1-2,5 \mathrm{~mm}$ compr. prolongado, apêndice ventral ca. $1 \mathrm{~mm}$ compr.; ovário 3-locular, livre, glabro; estilete 4-6 mm compr., amarelo, filiforme, glabro, estigma punctiforme. Cápsula 3-3,5 × 1,5-2,5 mm, atropurpúrea; sementes ca. $0,5 \mathrm{~mm}$ compr., curvas, superfície foveolada.

Material examinado: Fazenda Paraíso, trilha para Casinha Branca, 'Escada de Pedras', 11.IV.2002, fl., fr. e bot., R.A. Pacheco et al. 136 (HUFU); Fazenda Paraíso, estrada para Casinha Branca, 'Condomínio de Pedras', 7.XII.2002, fl., fr. e bot., R. L. Volpi et al. 463 (HUFU); Paraíso Selvagem, trilha para cachoeira Salto Solitário, 11.III.2003, fl., fr. e bot., $R$. Romero et al. 6727 (HUFU).
Microlicia euphorbioides ocorre nos estados de São Paulo, Minas Gerais, Mato Grosso e Goiás. Esta espécie é encontrada exclusivamente em campo rupestre nas serras de Delfinópolis. Coletada com botões, flores e frutos nos meses de março, abril e dezembro.

36. Microlicia fasciculata Mart., Nov. Gen. Sp. Pl. 3:105. 1820.

Subarbustos, $40-60 \mathrm{~cm}$ alt. Ramos jovens quadrangulares, adultos subcilíndricos, decorticantes, áfilos para a base. Indumento dos ramos e face adaxial e abaxial das folhas viloso, do hipanto e lacínias do cálice hirsuto, e com tricomas glandulares sésseis. Folhas opostas sésseis; lâmina 3-10 × 1,5-6 mm, concolor, elíptica, oval ou oval-lanceolada, ápice agudo, apiculado, base arredondada, margem ciliado-glandulosa, 1 par de nervuras acródromas basais. Flores 5-meras, solitárias, terminais ou axilares; pedicelo 1-2 mm compr; hipanto ca. $4 \times 2-2,5 \mathrm{~mm}$, oblongo, urceolado; lacínias do cálice 2-3×1-1,5 mm, triangulares, ápice longo apiculado; pétalas 7,5-10,5 ×6-8 mm, magenta, obovais, ápice agudo a arredondado, curtoapiculado, margem não ciliada; estames 10 , desiguais, amarelos; estames antepétalos com filetes 3-4 mm compr., glabros, anteras 2,5-3× $0,7 \mathrm{~mm}$, rostro $0,5-0,8 \mathrm{~mm}$ compr., oblongas, uniporosas, conectivo ca. $1 \mathrm{~mm}$ compr. prolongado abaixo das tecas, inapendiculado; estames ante-sépalos com filetes $4-5 \mathrm{~mm}$, glabros, anteras 3-3,5 $\times 0,7-1 \mathrm{~mm}$, rostro ca. $0,8 \mathrm{~mm}$ compr., oblongas, uniporosas, conectivo 2-3 mm compr. prolongado, apêndice ventral ca. 0,5 mm compr., expandido; ovário 3-locular, livre, glabro; estilete 8-9 mm compr., amarelo, ápice róseo, reto, glabro, estigma punctiforme. Cápsula 2,5-4 × 2-3 mm, castanha; sementes ca. $0,5 \mathrm{~mm}$ compr., curvas, superfície foveolada. Material examinado: Fazenda Paraíso, trilha para Casinha Branca, 'Escada de Pedras', 11.IV.2002, fl., fr.e bot., R.A. Pacheco et al. 96(HUFU); idem, 11.X.2002, fl., fr. e bot., R. Romero et al. 6440 (HUFU); Fazenda Paraíso, trilha das cachoeiras, 13.III.2003, fl., fr. e bot., R. Romero et al. 6751 (HUFU); idem, 23.X.2003, fl., fr. e bot., R.L. Volpi et al. 754 (HUFU); Fazenda Paraíso, estrada para Casinha Branca, 'Condomínio 
de Pedras', 25.X.2003, fl. e fr., R. L. Volpi et al. 764 (HUFU); idem, 25.X.2003, fr. e bot., J. N. Nakajima et al. 3650 (HUFU); Fazenda Paraíso, trilha das cachoeiras, 29.XI.2003, fl., fr. e bot., J. N. Nakajima et al.3796(HUFU); Fazenda Paraíso, trilha para Casinha Branca, 'Escada de Pedras', 14.IX.2004, fl., E. K. O. Hattori et al. 377 (HUFU); idem, 9.XI.2005, fl., fr. e bot., R. Romero et al. 7293 (HUFU); idem, 9.XI.2005, fl., fr. e bot., R. Romero et al. 7299 (HUFU).

Microlicia fasciculata ocorre nos estados de São Paulo, Minas Gerais, Goiás, Bahia e no Distrito Federal. Nas serras de Delfinópolis é encontrada em campo rupestre e, mais raramente, em campo úmido. Coletada com flores em março, abril e de setembro a novembro, e com frutos em março, abril, outubro e novembro.

\section{Microlicia fulva (Spreng.) Cham.,} Linnaea 9: 391. 1834.

Subarbustos, 30-80 cm alt. Caule subcilíndrico, decorticante, áfilo para a base, ramos jovens quadrangulares a subquadrangulares. Indumento dos ramos, faces adaxial e abaxial das folhas, hipanto e lacínias do cálice velutíneo, e com tricomas glandulares sésseis. Folhas opostas, pecíolo ca. 0,5 mm compr.; lâmina 3$10 \times 1,5-6 \mathrm{~mm}$, concolor, elíptica, oval a oboval, ápice agudo, curto-apiculado, base arredondada, margem inteira ou crenulada, ciliada, 1-2 pares de nervuras acródromas basais. Flores 5-meras, solitárias, terminais e axilares; pedicelo 1,5-2,5 mm compr.; hipanto 2-3×1,5-2,5 mm, oblongocampanulado; lacínias do cálice 3-4×0,7-1 mm, triangulares, ápice acuminado; pétalas 8,4-13,6 $\times 5-6,5 \mathrm{~mm}$, púrpuras, oblongas a obovais, ápice arredondado-acuminado, margem não ciliada; estames 10, desiguais, estames antepétalos com filetes 2,5-3,5 mm compr., purpúreos, glabros, anteras 1,5-2 × 0,3 mm, amarelas, rostro 0,3$0,5 \mathrm{~mm}$ compr., oblongas, uniporosas, conectivo 0,7-1,5 mm compr., prolongado abaixo das tecas, amarelo, apêndice ventral ca. $0,5 \mathrm{~mm}$ compr., expandido; estames ante-sépalos com filetes 3-4 mm compr., purpúreos, glabros, anteras 2-2,5 ×0,5 mm, purpúreas, rostro 0,5$0,8 \mathrm{~mm}$ compr., uniporosas, conectivo $2,5-4 \mathrm{~mm}$ compr. prolongado, purpúreo; apêndice ventral
1-1,5 mm compr., expandido; ovário 3-locular, livre, glabro; estilete 5-7 mm compr., purpúreo, filiforme, glabro, estigma truncado. Cápsula 2,5-4 × 2-3 mm, castanha; sementes ca. 1,5 $\times 0,5 \mathrm{~mm}$, curvas, superfície foveolada.

Material examinado: Fazenda Paraíso, trilha para Casinha Branca, 'Escada de Pedras', 11.IV.2002, fl., fr. e bot., R. A. Pacheco et al. 106 (HUFU); idem, 5.XII.2002, fl., fr. e bot., R. L. Volpi et al. 397 (HUFU); idem, 10.III.2003, fl., fr. e bot., R. L. Volpi et al. 500 (HUFU); Fazenda Paraíso, estrada para Casinha Branca, 'Condomínio de Pedras', 12.III.2003, fl., fr. e bot., $R$. L. Volpi et al. 543 (HUFU); idem, 12.III.2003, fl., fr. e bot., R. L. Volpi et al. 597 (HUFU); Fazenda Paraíso, trilha para Casinha Branca, 'Escada de Pedras', 15.V.2003, fl., fr. e bot., R. L. Volpi et al. 612 (HUFU); idem, 15.V.2003, fl., fr. e bot., R. Romero et al. 6885 (HUFU); Fazenda Paraíso, estrada para Casinha Branca, 'Condomínio de Pedras', 17.V.2003, fl., fr. e bot., R. A. Pacheco et al. 636 (HUFU); idem, 17.V.2003, fl., fr. e bot., R. L. Volpi et al. 721 (HUFU); Fazenda Paraíso, trilha das cachoeiras, 23.X.2003, fl., fr. e bot., R. L. Volpi et al. 744 (HUFU); Fazenda Paraíso, trilha para Casinha Branca, 'Escada de Pedras', 9.XI.2005, fl., R. Romero et al. 7290 (HUFU); idem, 9.XI.2005, fl., fr. e bot., R. Romero et al. 7297 (HUFU).

Microlicia fulva ocorre nos estados do Rio de Janeiro, Minas Gerais, Goiás, Bahia e no Distrito Federal. Esta espécie é encontrada nas serras de Delfinópolis em campo rupestre e, ocasionalmente, em campo limpo arenoso e cerrado. Coletada com botões, flores e frutos de março a maio e de outubro a dezembro.

38. Microlicia inquinans Naudin, Ann. Sci. Nat. Ser. 3, Bot. 3:171. 1845.

Subarbustos, 0,3-1 cm alt. Ramos jovens quadrangulares, adultos subcilíndricos. Indumento dos ramos moderadamente hirsuto, das faces adaxial e abaxial das folhas, hipanto e lacínias do cálice piloso-glanduloso, glutinoso, tricomas glandulares sésseis e pedicelados, raramente entremeado com tricomas simples. Folhas opostas, sésseis; lâmina 9-20×2-6 mm, concolor, oval-oblonga a oval-lanceolada, ápice agudo, base arredondada, margem crenulada, raramente ciliada, tricomas simples, ambas as faces vernicosas, 2-3 pares de nervuras acródromas basais, nervura central proeminente na face abaxial. Flores 5-meras, solitárias e/ 
ou reunidas em grupos de 3-6, terminais; pedicelo ca. $1 \mathrm{~mm}$ compr.; hipanto 3-4 ×3-3,5 mm, campanulado; lacínias do cálice 3,5-5,5×1,5 mm, triangulares, ápice agudo-apiculado; pétalas 1118×5-9 mm, purpúreas, obovais, raro oblongas, ápice agudo-acuminado, margem não ciliada; estames 10, desiguais; estames antepétalos com filetes 4,5-6,5 $\mathrm{mm}$ compr., metade inferior amarela, metade superior púrpura, glabros, anteras 2,5-3 $\times 0,7 \mathrm{~mm}$, amarelas, rostro 0,5-0,7 mm compr., oval-oblongas, uniporosas, conectivo 1-1,5 mm compr., prolongado abaixo das tecas, amarelo, apêndice ventral ca. 0,7 mm compr., amarelo, expandido; estames ante-sépalos com filetes 5,5-7 mm compr., metade inferior amarela, metade superior púrpura, glabros, anteras 2,5-3 $\times 0,8-1 \mathrm{~mm}$, purpúreas, rostro ca. $0,8 \mathrm{~mm}$ compr., oval-oblongas, uniporosas, conectivo 3-5 mm compr. prolongado, púrpura, apêndice ventral 1,52 mm compr., púrpura, expandido; ovário 3locular, livre, glabro; estilete 5-7,5 mm compr., púrpura, filiforme, glabro, estigma punctiforme. Cápsula 3-4,5×3-4 mm, atropurpúrea; sementes ca. $1 \times 0,5 \mathrm{~mm}$, curvas, superfície foveolada.

Material examinado: Fazenda Paraíso, estrada para Casinha Branca, 'Condomínio de Pedras', 10.IV.2002, fl. e bot., R. Romero et al. 6254 (HUFU); Fazenda Paraíso, trilha para Casinha Branca, 'Escada de Pedras', 11.IV.2002, fl., fr. e bot., R. A. Pacheco et al. 91 (HUFU); idem, 10.III.2003, fl. e bot., $R$. L. Volpi et al. 482 (HUFU); idem, 10.III.2003, fl., fr. e bot., $R$. $L$. Volpi et al. 536 (HUFU); Paraíso Selvagem, trilha para cachoeira Salto Solitário, 11.III.2003, fl. e bot., R. Romero et al. 6706 (HUFU); Fazenda Paraíso, trilha para Casinha Branca, 'Escada de Pedras', 15.V.2003, fl., fr. e bot., R. L. Volpi et al. 634 (HUFU).

Microlicia inquinans ocorre somente no sudoeste e noroeste do estado de Minas Gerais. Nas serras de Delfinópolis é encontrada somente em campo rupestre. Coletada com botões, flores e frutos de março a maio.

\section{Microlicia isophylla DC., Prodromus} 3:120. 1828.

Subarbustos, 40-50 cm alt. Ramos jovens quadrangulares, folhosos, adultos subcilíndricos, decorticantes, áfilos para a base. Indumento dos ramos, faces adaxial e abaxial das folhas, hipanto e lacínias do cálice glanduloso, tricomas glandulares sésseis. Folhas opostas, sésseis; lâmina 2-3×0,5-4 mm, concolor, ereta, elíptica ou oblongo-lanceolada, ápice acuminado, curtoapiculado, base atenuada, margem inteira, não ciliada, uma nervura central evidente em ambas as faces. Flores 5-meras, solitárias, terminais e axilares; pedicelo 1,5-2 mm compr.; hipanto ca. 2,5 × 1-1,5 mm, oblongo; lacínias do cálice 1,52,5 $\times 0,5 \mathrm{~mm}$, linear-triangulares, ápice apiculado; pétalas $6,5-8 \times 3,5-4 \mathrm{~mm}$, púrpuras, obovais, ápice agudo-acuminado, margem não ciliada; estames 10, desiguais, filetes purpúreos, glabros, anteras oval-oblongas, uniporosas; estames antepétalos com filetes 3-3,5 mm compr., anteras ca. $1 \times 0,5 \mathrm{~mm}$, amarelas, rostro $0,1-$ 0,4 mm, compr. conectivo ca. $1 \mathrm{~mm}$ compr., prolongado abaixo das tecas, amarelo, apêndice ventral ca. 0,3 mm compr., amarelo, expandido; estames ante-sépalos com filetes ca. $4 \mathrm{~mm}$ compr., anteras ca. 1,5 ×0,5 mm, purpúreas, rostro ca. 0,1-0,4 mm compr., conectivo ca. 2 mm compr. prolongado, púrpura, apêndice ventral ca. 1,5 mm compr., amarelo, expandido; ovário 3-locular, livre, glabro; estilete ca. 3,5 mm compr., amarelo, ápice púrpura, filiforme, glabro, estigma truncado. Cápsula 3-3,5 ×2-2,5 mm, castanha; sementes ca. $0,5 \times 0,3 \mathrm{~mm}$, curvas, superfície foveolada.

Material examinado: Serra do Cemitério, trilha do Zé Carlinho, 9.X.2002, fr., J. N. Nakajima et al. 3210 (HUFU); Fazenda Paraíso, estrada para Casinha Branca, 'Condomínio de Pedras', 12.III.2003, fl. e bot., R. L. Volpi et al. 588 (HUFU).

Material adicional examinado: BRASIL, MINAS GERAIS: São Roque de Minas, Parque Nacional da Serra da Canastra, estrada para a nascente do rio São Francisco, 20.III.1996, fl., fr. e bot., R. Romero \& J.N. Nakajima et al. 3382 (HUFU).

Microlicia isophylla ocorre nos estados de São Paulo, Rio de Janeiro e Minas Gerais. Esta espécie é encontrada somente em campo rupestre nas serras de Delfinópolis. Coletada com botões e flores em março e frutos em outubro.

40. Microlicia polystemma Naudin, Ann. Sci. Nat. Ser. 3, Bot. 3:179. 1845.

Subarbustos, 0,2-1 m alt. Ramos jovens quadrangulares, folhosos, adultos subquadrangulares. Indumento dos ramos, faces adaxial 
e abaxial das folhas, hipanto e lacínias do cálice hirsuto, e com tricomas glandulares sésseis. Folhas opostas, sésseis; lâmina 4-12×2-6 mm, concolor, oval-lanceolada, ápice agudo, apiculado, base arredondada, margem inteira ou levemente serreada, longo-ciliada, 1-2 pares de nervuras acródromas basais. Flores 5-meras, solitárias, terminais e axilares; pedicelo 1,5-2 mm compr.; hipanto 4-4,5 $\times 2$ $\mathrm{mm}$, oblongo; lacínias do cálice 3-3,5×0,5-1 $\mathrm{mm}$, triangulares, ápice acuminado, longoapiculado, margem ciliada; pétalas 9-13 × 6$11 \mathrm{~mm}$, púrpuras, obovais, ápice arredondado, raramente curto-apiculado, margem não ciliada; estames 10, desiguais, amarelos, glabros, anteras oblongas, uniporosas; estames antepétalos com filetes $3-4 \mathrm{~mm}$ compr., anteras $2-3 \times 0,5-0,7 \mathrm{~mm}$, rostro $0,3-0,6 \mathrm{~mm}$ compr., conectivo $0,7-1 \mathrm{~mm}$ compr., prolongado abaixo das tecas, inapendiculado; estames ante-sépalos com filetes $3,5-4,5 \mathrm{~mm}$ compr., anteras $2,5-3,5$ $\times 0,5-0,7 \mathrm{~mm}$, rostro $0,5-0,7 \mathrm{~mm}$ compr., conectivo 1,5-2 $\mathrm{mm}$ compr. prolongado, apêndice ventral ca. $0,5 \mathrm{~mm}$ compr., expandido; ovário 3-locular, livre, glabro; estilete 6-8,5 mm compr., púrpura ou amarelo com ápice púrpura, filiforme, glabro, estigma punctiforme. Cápsula 4-5 $\times 2,5-3 \mathrm{~mm}$, castanha; sementes $0,7-1 \times$ $0,5 \mathrm{~mm}$, levemente curvas, superfície foveolada. Material examinado: Fazenda Paraíso, trilha para cachoeira Triângulo, 6.XII.2002, fl., fr. e bot., J.N. Nakajima et al. 3364 (HUFU); Fazenda Paraíso, trilha para Casinha Branca, 'Escada de Pedras', 10.III.2003, fl., fr. e bot., R.L. Volpi et al. 491 (HUFU); Fazenda Paraíso, trilha das cachoeiras, 13.III.2003, fl. e bot., $R$. Romero et al. 6749 (HUFU); Estrada para a Gurita, 14.V.2003, fl., fr. e bot., R. Romero et al. 6826 (HUFU); Fazenda Paraíso, trilha das cachoeiras, 23.X.2003, fl., fr. e bot., J. N. Nakajima et al. 3607 (HUFU); Fazenda Paraíso, trilha para Casinha Branca, 'Escada de Pedras', 14.IX.2004, fl. e bot., C. A. Faria et al. 63 (HUFU); idem, 9.XI.2005, fl., fr. e bot., $R$. Romero et al. 7284 (HUFU); idem, 9.XI.2005, fl., fr. e bot., $R$. Romero et al. 7302 (HUFU).

Microlicia polystemma ocorre nos estados de São Paulo, Minas Gerais, Mato Grosso e Goiás. Nas serras de Delfinópolis esta espécie é encontrada em campo rupestre e, mais raramente, em campo úmido. Coletada com botões e flores em março, maio e de setembro a dezembro e com frutos em março, maio e de outubro a dezembro.

41. Ossaea congestiflora (Naudin) Cogn., in Mart. \& Eichler Fl. bras. 14(4): 553. 1888.

Fig. 3 d-e

Subarbustos ou arbustos, 0,4-1,5 m alt. Ramos cilíndricos. Indumento dos ramos e face abaxial das folhas densamente viloso, da face adaxial das folhas, brácteas, hipanto e lacínias do cálice densamente adpresso-setoso. Folhas opostas, pecíolo 3-8 mm compr.; lâmina concolor, elíptica, oval-lanceolada, ápice agudo a arredondado, base arredondada, raramente atenuada, margem crenulada, ciliada, face adaxial bulada, 2 pares de nervuras acródromas basais ou 5-8(-11) mm compr. suprabasais, nervuras impressas na face adaxial, proeminentes na face abaxial. Cimeiras glomeriformes, axilares; brácteas 4-5,5×3-4 mm, foliáceas, ovais, ápice agudo, raramente apiculado, margem ciliada. Flores 5-meras, sésseis; hipanto ca. 2,5 ×3 mm, campanulado; cálice com lacínias internas translúcidas, triangulares, margem ciliada, lacínias externas translúcidas, linear-triangulares, margem ciliada; pétalas $3,5-4 \times 1 \mathrm{~mm}$, brancas, lanceoladas, ápice agudo, margem não ciliada; estames 10, desiguais, creme, filetes 3-4 mm compr., glabros, anteras $2-2,5 \times 0,5 \mathrm{~mm}$, oblongas, uniporosas, conectivo não prolongado abaixo das tecas, inapendiculado ventralmente, lobado dorsalmente nos estames antepétalos, bilobado nos estames ante-sépalos; ovário 3locular, adnato ao hipanto na metade inferior, ápice setoso; estilete 5,5-7,5 mm compr., creme, filiforme, glabro, estigma punctiforme. Baga 3-4 $\times 3-3,5 \mathrm{~mm}$, atropurpúrea; sementes $0,7-1 \times 0,5$ $\mathrm{mm}$, levemente curvas, superfície lisa.

Material examinado: Fazenda Paraíso, estrada para Casinha Branca, 'Condomínio de Pedras', 13.IV.2002, fr., R. L. Volpi et al. 101 (HUFU); idem, 13.IV.2002, fr., R. L. Volpi et al. 109 (HUFU); Fazenda Paraíso, trilha para cachoeira Triângulo, 6.XII.2002, fl., fr. e bot., J. N. Nakajima et al. 3383 (HUFU); Fazenda Paraíso, trilha para Casinha Branca, 'Escada de Pedras', 15.V.2003, fr., R. Romero et al. 6862 (HUFU); Fazenda Paraíso, estrada para Casinha Branca, 'Condomínio de Pedras', 17.V.2003, fr., R. A. Pacheco et al. 634 
(HUFU); idem, 17.V.2003, fr., R.L. Volpi et al. 718 (HUFU); Fazenda Paraíso, trilha para Casinha Branca, 'Escada de Pedras', 9.XI.2005, fl. e bot., $R$. Romero et al. 7298 (HUFU).

Ossaea congestiflora ocorre nos estados de São Paulo, Minas Gerais, Goiás e no Distrito Federal. Esta espécie é encontrada em campo rupestre, cerrado rupestre, campo limpo e cerrado das serras de Delfinópolis. Coletada com flores em novembro e dezembro e com frutos em abril, maio e dezembro.

42. Pterolepis repanda (DC.) Triana, Trans. Linn. Soc. Bot. 28(1): 39. 1871. Fig. $3 \mathrm{f}-\mathrm{h}$

Ervas, ca. $10 \mathrm{~cm}$ alt. Ramos quadrangulares. Indumento dos ramos densamente adpressosetoso, das faces adaxial e abaxial das folhas e nervuras densamente estrigoso, hipanto com tricomas penicilados, não glandulares. Folhas opostas, pecíolo 2-3,5 mm compr.; lâmina 20 28×9-11 mm, concolor, oval-lanceolada, ápice agudo, longo-apiculado, base arredondada, raramente atenuada, margem inteira, ciliada, um par de nervuras acródromas basais. Cimeiras reduzidas, terminais. Flores 4-meras; pedicelo ca. $1 \mathrm{~mm}$ compr.; hipanto ca. $4 \times 3 \mathrm{~mm}$, campanulado; lacínias do cálice ca. $4,5 \times 4,5 \mathrm{~mm}$, triangulares, ápice agudo, terminado em seta longa; pétalas 12,5-15 × 11-11,5 mm, róseas, obovais, ápice truncado, margem ciliadoglandulosa; estames 8 , subiguais, filetes 6-7 mm compr., amarelos, ápice púrpura, anteras 4,5$5,5 \times 0,7-1 \mathrm{~mm}$, púrpuras, oblongas, uniporosas, conectivo $0,7-1 \mathrm{~mm}$ compr. prolongado abaixo das tecas, bilobado ventralmente; ovário 4locular, livre, ápice setoso; estilete ca. 10,5 mm compr., púrpura com base creme, reto, glabro, estigma punctiforme. Cápsula ca. $5 \times 2,5 \mathrm{~mm}$, castanha; sementes ca. $0,5 \mathrm{~mm}$ compr., subcocleadas, superfície tuberculada.

Material examinado: Fazenda Paraíso, estrada para Casinha Branca, 'Condomínio de Pedras', 12.III.2003, fr., R. L. Volpi et al. 556 (HUFU).

Material adicional examinado: BRASIL, MINAS GERAIS: São Roque de Minas, Parque Nacional da Serra da Canastra, estrada para cachoeira dos Rolinhos, 14.V.1995, fl., R. Romero et al. 2286 (HUFU).
Pterolepis repanda ocorre no Paraguai e Bolívia e no Brasil nos estados de São Paulo, Minas Gerais, Mato Grossso do Sul, Mato Grosso, Goiás, Bahia e no Distrito Federal. Nas serras de Delfinópolis esta espécie é encontrada em campo rupestre. Coletada com frutos em março.

43. Svitramia hatschbachii Wurdack, Boletim Museu Botânico Municipal 10:1. 1973.

Subarbustos ou arbustos, 0,6-1,5 m compr.. Caule cilíndrico, ramos subcilíndricos. Indumento dos ramos, faces adaxial e abaxial das folhas, e bractéolas glutinoso, com tricomas glandulares sésseis, do hipanto e lacínias do cálice furfuráceo, glutinoso. Folhas opostas, sésseis; lâmina 4,2-10,5×1,5-4,6 cm, elíptica, oval-lanceolada, ápice agudo a arredondado, base arredondada a levemente cordada, margem estrigoso-ciliada, 3-4 pares de nervuras acródromas basais. Dicásios simples ou compostos, terminais; bractéolas 6-7×3,5$4 \mathrm{~mm}$, membranosas, oblongas, ápice obtuso, margem esparsamente ciliada. Flores 5-meras; pedicelo 1-2 mm compr.; hipanto 3-4×3,5-4 mm, campanulado; lacínias do cálice $2-3,5 \times$ 2-3 mm, oblongas, ápice arredondado, margem inteira, raro ciliada no ápice; pétalas 8-14 $\times$ 7-13 mm, magenta, obovais, ápice truncado, margem ciliada no ápice; estames 10, desiguais, filetes 2,5-3,5 $\mathrm{mm}$ compr., róseos, glabros, anteras 2-2,5 $\times 0,7 \mathrm{~mm}$, amarelas, oblongas, uniporosas, conectivo ca. $0,3 \mathrm{~mm}$ compr., prolongado abaixo das tecas, espessado no dorso, estames antepétalos ventralmente inapendiculado, estames antesépalos ventralmente curto bilobado nos estames ante-sépalos; ovário 5-locular, adnato ao hipanto na metade inferior, adpresso-setoso no ápice; estilete ca. $4 \mathrm{~mm}$ compr., ápice creme, base rósea, filiforme, ápice curvo, glabro, estigma punctiforme. Cápsula 4-6× 4-5 mm, marrom; sementes ca. 0,5 mm compr., cocleadas, superfície papilosa.

Material examinado: Fazenda Paraíso, estrada para Casinha Branca, 'Condomínio de Pedras', 10.IV.2002, fl. e bot., $R$. Romero et al. 6241 (HUFU); Fazenda Paraíso, trilha para Casinha Branca, 'Escada de Pedras', 11.IV.2002, fl. e bot., R. A. Pacheco et al. 98 
(HUFU); Fazenda Paraíso, trilha das cachoeiras, 13.III.2003, fl. e bot., R. Romero et al. 6759 (HUFU); estrada para a Gurita, 14.V.2003, fl., fr. e bot., R. Romero et al. 6824 (HUFU); Fazenda Paraíso, trilha para Casinha Branca, 'Escada de Pedras',15.V.2003, fl., fr. e bot., R. L. Volpi et al. 621 (HUFU); Fazenda Paraíso, estrada para Casinha Branca, 'Condomínio de Pedras', 17.V.2003, fl., fr. e bot., R. A. Pacheco et al. 617 (HUFU); idem, 17.V.2003, fl., fr. e bot., R. $L$. Volpi et al. 681 (HUFU); Fazenda Paraíso, trilha para Casinha Branca, 'Escada de Pedras', 14.IX.2004, fr., E. K. O. Hattori et al. 397 (HUFU); idem, 14.IX.2004, fr., R. Romero et al. 7080 (HUFU); Estrada para a Gurita, 8.XI.2005, fr., R. Romero et al. 7272 (HUFU).

Svitramia hatschbachii ocorre no sul e sudoeste do estado de Minas Gerais. Esta espécie é encontrada nos campos rupestres das serras de Delfinópolis. Coletada com flores de março a maio e com frutos em maio, setembro e novembro.

44. Svitramia integerrima R. Romero \& A.B. Martins, Kew Bull. 58(2): 403. 2003.

Fig. 3 i-k

Subarbustos ou arbustos, $0,6-2,5 \mathrm{~m}$ alt. Ramos jovens subcilíndricos, adultos cilíndricos. Indumento dos ramos e faces adaxial e abaxial das folhas piloso-glanduloso, com tricomas glandulares sésseis, das brácteas, hipanto e lacínias do cálice piloso-glanduloso, com tricomas glandulares pedicelados e sésseis. Folhas opostas, sésseis, patentes, semiamplexicaules; lâmina 2,2-6,5 × 1,5-4 cm, concolor, oval a oval-lanceolada, ápice agudo, raro curtoacuminado, base arredondada a subcordada, margem inteira, raro estrigoso-ciliada, 5-7 pares de nervuras acródromas basais, proeminentes em ambas as faces. Dicásios simples ou compostos, terminais; bractéolas 8-9 mm compr., translúcidas, côncavas, margem ciliado-glandulosa. Flores 5-meras; pedicelo 1,5-3,5 mm compr.; hipanto ca. $3,5 \times 3 \mathrm{~mm}$, campanulado; lacínias do cálice 1,5-3,5 × 1,5 mm, oval-triangulares, ápice arredondado, margem ciliado-glandulosa; pétalas 6-8 × 4-6,5 $\mathrm{mm}$, brancas, obovais, ápice arredondado, margem ciliado-glandulosa, principalmente no ápice; estames 10, subiguais, creme, filetes 3-4 mm compr., glabros, anteras 2,5-3,5 $\times 0,5 \mathrm{~mm}$, oblongas, uniporosas, conectivo
0,3-0,5 mm compr., prolongado abaixo das tecas, dorso espessado, apêndice ventral bilobado; ovário 5-locular, adnato ao hipanto na metade inferior, ápice adpresso-setoso; estilete 4-5,5 mm compr., creme, filiforme, ápice curvo, glabro, estigma punctiforme. Cápsula ca. $4 \times 3-4 \mathrm{~mm}$, marrom; sementes 2-2,5×1-1,5 mm, cocleadas, superfície papilosa.

Material examinado: Fazenda Paraíso, trilha para Casinha Branca, 'Escada de Pedras', 5.XII.2002, fr., R. L. Volpi et al. 373 (HUFU); idem, 15.V.2003, fl. e bot., R. Romero et al. 6853 (HUFU); Paraíso selvagem, trilha para Salto do Canyon, 16.V.2003, fl. e bot., R. Romero et al. 6918 (HUFU); Fazenda Paraíso, estrada para Casinha Branca, 'Condomínio de Pedras', 17.V.2003, , fl. e bot., R. L. Volpi et al. 651 (HUFU); idem, 17.V.2003, fl. e bot., R. L. Volpi et al. 706 (HUFU); Fazenda Paraíso, trilha para Casinha Branca, 'Escada de Pedras', 14.IX.2004, fr., E. K. O. Hattori et al. 388 (HUFU); idem, 14.IX.2004, fl. e fr., R. Romero et al. 7089 (HUFU); idem, 9.XI.2005, fr., $R$. Romero et al. 7291 (HUFU).

Svitramia integerrima é endêmica do estado de Minas Gerais ocorrendo somente nas serras de Delfinópolis, onde é encontrado em campo rupestre e, ocasionalmente, em cerrado rupestre e cerrado. Coletada com flores de maio e setembro e com frutos em setembro, novembro e dezembro.

45. Svitramia pulchra Cham., Linnaea 9:446. 1834.

Subarbustos ou arbustos, $0,8-1,5 \mathrm{~m}$ alt. Ramos jovens subcilíndricos, adultos cilíndricos, decorticantes. Indumento dos ramos, faces adaxial e abaxial das folhas estrigoso, tricomas bulboso, bractéolas com tricomas glandulares sésseis, do hipanto e lacínias do cálice furfuráceo, com tricomas glandulares sésseis e adpresso-setosos. Folhas opostas, sésseis ou pecíolo 3-4 mm compr.; lâmina 7-9,5 × 1,6$3,5 \mathrm{~cm}$, discolor, elíptica, raramente oboval, ápice agudo, base arredondada a atenuada, margem estrigoso-ciliada, 3 pares de nervuras acródromas basais. Dicásios reduzidos, terminais; bractéolas 6-8 $\mathrm{mm}$ compr., membranáceas, margem ciliada. Flores 5meras; pedicelo 1-1,5 mm compr.; hipanto 2,5$3 \times 2,5-3 \mathrm{~mm}$, campanulado; lacínias do cálice 
2-3 × 1,5-2 mm, ápice arredondado, margem setoso-ciliada; pétalas 9-11 × 6-11 mm, magenta, obovais, ápice retuso, margem inteira, base raramente ciliada; estames 10 , subiguais, filetes 3-3,5 mm compr., róseos, glabros, anteras $2-2,5 \times 0,5 \mathrm{~mm}$, creme, oblongas, uniporosas, conectivo ca. 0,3 mm compr., prolongado abaixo das tecas, inapendiculado; ovário 5-locular, adnato ao hipanto na metade inferior, ápice adpresso-setoso; estilete 4-5 mm compr., metade superior creme, metade inferior róseo, filiforme, ápice curvo, glabro, estigma punctiforme. Cápsula 4-7 ×4-5 mm, marrom; sementes $0,5-0,7 \times 0,3 \mathrm{~mm}$, cocleadas, superfície papilosa.

Material examinado: Serra do Cemitério, trilha do Zé Carlinho, 9.X.2002, fr., J. N. Nakajima et al. 3211 (HUFU); Paraíso Selvagem, trilha para o Salto Solitário, 16.V.2003, fl., fr. e bot., R. A. Pacheco et al. 587 (HUFU); Paraíso Selvagem, trilha para mata do Canyon, 22.X.2003, fr., J. N. Nakajima et al. 3547 (HUFU); Paraíso Selvagem, trilha para o Salto do Canyon, 27.XI.2003, fr., R. A. Pacheco et al. 708 (HUFU); Estrada para Delfinópolis, cachoeiras do ribeirão Bom Jesus, 28.XI.2003, fr., R. Romero et al. 7034 (HUFU).

Svitramia pulchra ocorre no sul e sudoeste do estado de Minas Gerais. Esta espécie é encontrada em campo rupestre das serras de Delfinópolis. Coletada com flores em maio e com frutos em maio, outubro e novembro.

\section{Svitramia sp. nov.}

Subarbustos ou arbustos, ca. $80 \mathrm{~cm}$ alt. Caule cilíndrico a subcilíndrico, ramos achatados. Caule, ramos, faces adaxial e abaxial das folhas, brácteas, hipanto e lacínias do cálice glabros. Folhas opostas, sésseis, semiamplexicaule; lâmina 2,8-3,5×3,6-5 cm, discolor, cordiforme, ápice arredondado, terminado em tricoma espinescente único, base cordada, margem ciliado-estrigosa, 7-9 pares de nervuras acródromas basais, proeminentes na face abaxial. Dicásios simples ou compostos, reduzidos ou não, terminais; bractéolas 4-5 mm compr., côncavas, translúcidas, oblongas, margem ciliadoglandulosa, principalmente no ápice. Flores 5meras; pedicelo 3-4 mm compr.; hipanto 3,5-
$4 \times 4$ mm, campanulado; lacínias do cálice 3$4 \times 2 \mathrm{~mm}$, oval-triangulares, ápice arredondado, margem ciliado-glandulosa; pétalas 7-9,5 ×6$8,5 \mathrm{~mm}$, brancas, obovais, ápice arredondado, margem ciliado-glandulosa na metade superior; estames 10, subiguais, creme, filetes 3-4 mm compr., glabros, anteras 3-3,5 × 0,7-1 mm, oblongas, uniporosas, conectivo ca. $0,5 \mathrm{~mm}$ compr., prolongado abaixo das tecas, dorso espessado, apêndice ventral bilobado; ovário 5-locular, adnato ao hipanto na metade inferior, ápice ciliado-glanduloso; estilete 5,5-6 mm compr., creme, filiforme, ápice curvo, glabro, estigma punctiforme. Cápsula 4-5 ×3-4 mm, nigrescente; sementes ca. $0,5 \times 0,3 \mathrm{~mm}$, cocleadas, superfície papilosa.

Material examinado: Paraíso Selvagem, trilha para cachoeira Salto Solitário, 11.III.2003, fl., fr. e bot., $R$. Romero et al. 6707 (HUFU).

Svitramia sp. (não descrita até o momento) ocorre ao longo das serras do Complexo Canastra, a sudoeste de Minas Gerais. Nas serras de Delfinópolis é encontrada em campo rupestre. Coletada com flores e frutos em março.

47. Tibouchina aegopogon (Naudin) Cogn., in Mart. \& Eichler Fl. bras. 14(3): 383. 1885.

Fig. 3 1-m

Subarbustos, 0,4-1 m alt. Ramos subcilíndricos no ápice, cilíndricos na base, decorticantes. Indumento dos ramos, faces adaxial e abaxial das folhas, brácteas, hipanto e lacínias do cálice lepidoto. Folhas opostas, pecíolo 5-10 mm compr.; lâmina 8,8-16×3$6,5 \mathrm{~cm}$, concolor, elíptica, oval ou lanceolada, ápice agudo, base arredondada ou atenuada, margem inteira, 2 pares de nervuras acródromas basais, impressas na face adaxial, proeminentes na face abaxial. Panículas de glomérulos 23-49 cm compr., terminais; brácteas 5-6,5 × 1,5-3 mm, triangularlanceoladas, ápice agudo-acuminado, margem ciliada. Flores 5-meras; pedicelo 1,5-2,5 mm compr.; hipanto 9-10,5 × 7-7,5 mm, oblongocampanulado; lacínias do cálice 4,5-5 ×3-3,5 $\mathrm{mm}$, triangulares, ápice acuminado, margem ciliada; pétalas 23-26×17-18 mm, púrpuras, obovais, ápice retuso, assimétrico, margem 
ciliado-glandulosa; estames 10, desiguais, filetes creme, esparsamente vilosos, anteras creme, base púrpura, subuladas, uniporosas; estames antepétalos com filetes 12-13 mm compr., anteras 6,5-9 × 1-1,5 mm compr., conectivo 2,5-3 mm compr., prolongado abaixo das tecas, apêndice ventral ca. 0,5 mm compr., biauriculado, púrpura, viloso; estames antesépalos com filetes ca. $13 \mathrm{~mm}$ compr., anteras 11-12 ×1-1,5 mm, conectivo 4,5-5 mm compr. prolongado, apêndice ventral 0,7-1 mm compr., biauriculado, púrpura, viloso; ovário 5-locular, adnato ao hipanto na metade inferior, setoso; estilete 18,5-20 mm compr., creme, ápice róseo, filiforme, ápice curvo, glabro, estigma punctiforme. Cápsula 8-10 × 6-7 mm, atropurpúrea; sementes ca. $1 \times 0,5 \mathrm{~mm}$, cocleadas, superfície tuberculada.

Material examinado: Estrada para Fazenda Paraíso, 5.XII.2002, fl., fr. e bot, $R$. L. Volpi et al. 327 (HUFU); Fazenda Paraíso, trilha para Casinha Branca, 'Escada de Pedras', 5.XII.2002, fl., fr. e bot., R. L. Volpi et al. 402 (HUFU); Fazenda Paraíso, trilha para cachoeira Triângulo, 6.XII.2002, fl., fr. e bot., J. N. Nakajima et al. 3373 (HUFU); Fazenda do Sr. José Onório, estrada para 'Escada de Pedras', 29.XI.2003, fl., fr. e bot., J. N. Nakajima et al. 3783 (HUFU).

Tibouchina aegopogon ocorre nos estados de São Paulo, Minas Gerais e Goiás. Nas serras de Delfinópolis ocorre em campo rupestre, cerrado rupestre e campo limpo. Coletada com flores e frutos em novembro e dezembro.

48. Tibouchina bergiana Cogn., in Mart. \& Eichler Fl. bras. 14(3):316. 1885. Fig. 3 n-o

Arbustos, 60-80 cm alt. Ramos quadrangulares. Indumento dos ramos, face adaxial das folhas, hipanto e lacínias do cálice esparsamente a moderadamente estrigoso, da face abaxial das folhas e brácteas esparsamente seríceo. Folhas opostas, pecíolo 3-5 mm compr.; lâmina 10,2-13,5×3,5-4,3 cm, discolor, oblongolanceoladas, ápice agudo-acuminado, base arredondada, margem inteira, às vezes estrigosaciliada, 2-3 pares de nervuras acródromas basais, impressas na face adaxial, proeminentes na face abaxial. Panículas 7-10 cm compr., terminais e axilares; brácteas 8-10 × 4-6 mm, côncavas, ápice agudo, margem ciliada. Flores 5-meras; pedicelo 2-3,5 mm compr.; hipanto 56×3-4 mm, oblongo; lacínias do cálice 6-6,5× 3-4 mm, triangulares, ápice agudo, margem ciliada; pétalas 17-18,5×13,5-15 mm, púrpuras, obovais, ápice subretuso, levemente assimétrico, margem ciliada; estames 10 , subiguais, filetes 3,5-5 mm compr., creme, base vinácea, tricomas glandulares esparsos na metade inferior, anteras 5-5,5 ×0,8 mm, creme, base vinácea, subuladas, ápice atenuado, uniporosas, conectivo ca. 0,8 mm compr. prolongado abaixo das tecas, apêndice ventral curto bilobado, com tricomas glandulares; ovário 5-locular, adnato ao hipanto na metade inferior, ápice adpresso-setoso; estilete ca. $8 \mathrm{~mm}$ compr., vináceo, creme no ápice, filiforme, metade inferior setoso, estigma truncado.

Material examinado: Fazenda Paraíso, estrada para Casinha Branca, 'Condomínio de Pedras', 12.III.2003, fl. e bot., R. L. Volpi et al. 590 (HUFU); Fazenda Paraíso, trilha das cachoeiras, 13.III.2003, fl. e bot., R. Romero et al. 6750 (HUFU).

Tibouchina bergiana ocorre somente no estado de Minas Gerais. Esta espécie é encontrada nos campos rupestres das serras de Delfinópolis. Coletada com botões e flores no mês de março. Frutos não encontrados.

49. Tibouchina candolleana (Mart. ex DC.) Cogn., in Mart. \& Eichler Fl. bras. 14(3): 339. 1885.

Árvores, 2,5-5 $\mathrm{m}$ alt. Ramos quadrangulares no ápice, subquadrangulares. Indumento dos ramos, faces adaxial e abaxial das folhas, brácteas, hipanto e lacínias do cálice estrigoso, tricomas com ramificações curtas. Folhas opostas, pecíolo 6-12 mm compr.; lâmina 5-7,5 × 1-2,3 cm, discolor, elípticolanceolada, raramente oboval, ápice agudo, curto acuminado, base atenuada, margem levemente crenada, ciliada, 1-2 pares de nervuras acródromas, 3-6 $\mathrm{mm}$ compr. suprabasais, segundo par confluindo acima do primeiro. Panículas 3-7 cm compr., raramente flores solitárias, terminais e axilares; brácteas 5-8 × 1,5-2 mm, lanceoladas, ápice agudo, margem ciliada. Flores 5-meras; pedicelo 2-3 mm compr.; hipanto 5-6×4 mm, oblongo; lacínias 
do cálice 3,5-4,5 ×2,5-3 mm, triangulares, ápice agudo, margem ciliada; pétalas 24-25 × 14-45 $\mathrm{mm}$, púrpuras, obovais, ápice arredondado, assimétrico, margem ciliada; estames 10, desiguais, filetes creme com ápice púrpura, setoso-glanduloso nos três quarto inferiores, anteras creme, base púrpura, subuladas, uniporosas; estames antepétalos com filetes ca. $9 \mathrm{~mm}$ compr., anteras 6,5-7,5 $\times 0,8 \mathrm{~mm}$, conectivo ca. $0,8 \mathrm{~mm}$ compr., prolongado abaixo das tecas, apêndice ventral ca. 0,5 mm compr., com tricomas glandulares; estames ante-sépalos com filetes 12-13 mm compr., anteras 7-9 $\times$ 0,8 mm, conectivo 1-1,5 mm compr. prolongado, apêndice ventral ca. $0,8 \mathrm{~mm}$ compr., com tricomas glandulares; ovário 5-locular, adnato ao hipanto na metade inferior, ápice adpresso-setoso; estilete ca. $18 \mathrm{~mm}$ compr., púrpura, filiforme, setoso nos três quartos inferiores, estigma punctiforme. Cápsula 5-8×5-6 mm, atropurpúrea; sementes $0,5-0,7 \times 0,5 \mathrm{~mm}$, subcocleadas, superfície tuberculada.

Material examinado: Serra do Cemitério, trilha do Zé Carlinho, 9.X.2002, fl., fr. e bot., J. N. Nakajima et al. 3216 (HUFU); Fazenda Paraíso, trilha para Casinha Branca, 'Escada de Pedras', 14.IX.2004, fl., fr. e bot., E. K. O. Hattori et al. 391 (HUFU).

Tibouchina candolleana ocorre nos estados de Minas Gerais, Goiás, Bahia e no Distrito Federal. Nas serras de Delfinópolis é encontrada em campo rupestre e cerrado. Coletada com flores e frutos em setembro e outubro.

50. Tibouchina gracilis (Bonpl.) Cogn., in Mart. \& Eichler Fl. bras. 14(3): 386. 1885.

Fig. 3 r-s

Subarbustos, 60-70 cm alt. Ramos jovens quadrangulares a subquadrangulares, adultos cilíndricos. Indumento dos ramos, faces adaxial e abaxial das folhas, brácteas, hipanto e lacínias do cálice densamente setoso-seríceo. Folhas opostas, pecíolo 3-6 mm compr.; lâmina 5-9,5× 1-2,4 cm, concolor, lanceolada, ápice agudo, base arredondada, margem ciliada, 2 pares de nervuras acródromas basais, um par confluindo acima do primeiro par. Panículas de glomérulos 15-39,5 cm compr., terminais; brácteas 5,5-6×3,5-4 mm, triangulares, ápice curto-acuminado, margem ciliada. Flores 5-meras; pedicelo ca. 3 mm compr.; hipanto ca. $5 \times$ ca. $4 \mathrm{~mm}$, campanulado; lacínias do cálice ca. $5 \times 2 \mathrm{~mm}$, triangulares, ápice curto acuminado, margem ciliada; pétalas 15-16×89,5 mm, púrpuras, obovais, ápice arredondado, margem setoso-ciliada; estames 10, desiguais, vináceos, filetes glabros, anteras oblongas, uniporosas; estames antepétalos com filetes 6$6,5 \mathrm{~mm}$ compr., anteras ca. $6 \times 0,7 \mathrm{~mm}$, conectivo ca. $0,5 \mathrm{~mm}$ compr., prolongado abaixo das tecas, dorso lobado, apêndice ventral bilobado; estames ante-sépalos com filetes 7-8 mm compr., anteras 6,5-7,5 × $1 \mathrm{~mm}$, conectivo ca. 0,7 mm compr. prolongado, dorso auriculado, apêndice ventral bilobado; ovário 5-locular, adnato ao hipanto na metade inferior, ápice setoso; estilete ca. $16 \mathrm{~mm}$ compr., creme, filiforme, glabro, estigma truncado. Cápsula 5-7×4-5 mm, atropurpúrea; sementes ca. $0,5 \times 0,3 \mathrm{~mm}$, cocleadas, superfície tuberculada.

Material examinado: Fazenda Paraíso, trilha para cachoeira Triângulo, 6.XII.2002, fl. e bot., J. N. Nakajima et al. 3352 (HUFU); Fazenda Paraíso, trilha para Casinha Branca, 'Escada de Pedras', 10.III.2003, fl. e fr., R. L. Volpi et al. 540 (HUFU).

Tibouchina gracilis ocorre nas Guianas, Venezuela, Peru, Bolívia, Colômbia, Paraguai, Argentina e Uruguai e Brasil, sendo encontrada nos estados das Regiões Sul, Sudeste e CentroOeste e na Bahia. Nas serras de Delfinópolis é encontrada em campo rupestre e em campo úmido associado a campo rupestre. Coletada com flores em março e dezembro e com frutos em março.

51. Tibouchina heteromalla (D. Don.) Cogn., in Mart. \& Eichler Fl. bras. 14(3): 335. 1885.

Subarbustos ou arbustos, 1-1,5 m alt. Ramos quadrangulares, caniculados. Indumento dos ramos, face adaxial das folhas e nervuras da face adaxial densamente seríceo-estrigoso, da face abaxial das folhas densamente viloso, das brácteas, hipanto e lacínias do cálice densamente seríceo. Folhas opostas, pecíolo 1025 mm compr.; lâmina 7,5-15,5 × 4-8,3 cm, discolor, oval-lanceolada, ápice agudo, curto acuminado, base arredondada, margem inteira, às vezes ciliada, face adaxial bulada, face 
abaxial foveolada, 2 pares de nervuras acródromas basais, par marginal tênue. Panículas 6,5-18 cm compr., terminais; brácteas 7-7,5 × 3-3,5 mm, triangulares, levemente côncavas, ápice acuminado, margem ciliado-glandulosa. Flores 5-meras; pedicelo 12 mm compr; hipanto 3-4,5 $\times 2-3 \mathrm{~mm}$, oblongo; lacínias do cálice 5-6 × 1,5-2 mm, longotriangulares ou lanceoladas, ápice acuminado, margem ciliado-glanduosar; pétalas 12-13× 9-11 mm, púrpuras, obovais, ápice arredondado, levemente truncado, margem ciliado-glandulosa; estames 10, desiguais; estames antepétalos com filetes 4-4,5 mm compr., púrpuras, tricomas glandulares na metade inferior; anteras 3,5-4 $\times 0,7 \mathrm{~mm}$, creme, curvas, uniporosas, conectivo ca. $1 \mathrm{~mm}$ compr. prolongado abaixo das tecas, creme, glabro, raro com um tricoma glandular, apêndice ventral bilobado; estames antesépalos com filetes 5-5,5 $\mathrm{mm}$ compr., púrpuras, tricomas glandulares na metade inferior; anteras 4-4,5 × 0,5 mm, púrpuras, retas, uniporosas, conectivo ca. $1 \mathrm{~mm}$ compr. prolongado, púrpura, com tricomas glandulares, apêndice ventral curtobilobado; ovário 5-locular, adnato ao hipanto na metade inferior, ápice densamente seríceo; estilete 4-5 mm compr., púrpura, filiforme, curvo no ápice, densamente seríceo na metade inferior, estigma truncado. Cápsula 8-10 × 4-5 mm, atropurpúrea; sementes $0,5-0,7 \times 0,3-0,5 \mathrm{~mm}$, subcocleadas, superfície tuberculada.

Material examinado: Fazenda Paraíso, trilha para Casinha Branca, 'Escada de Pedras', 11.IV.2002, fl., fr. e bot., R. A. Pacheco et al. 99 (HUFU); idem, 10.III. 2003, fl., fr. e bot., R. L. Volpi et al. 493 (HUFU); Fazenda Paraíso, estrada para Casinha Branca, 'Condomínio de Pedras', 12.III.2003 fl. e bot., R. L. Volpi et al. 568 (HUFU); Estrada para a Gurita, 14.V.2003, fl., fr. e bot., R. A. Pacheco et al. 544 (HUFU); Fazenda Paraíso, trilha para Casinha Branca, 'Escada de Pedras', 15.V.2003, fl., fr. e bot., R. L. Volpi et al. 622 (HUFU); idem, 14.IX.2004, fr., E. K. O.Hattori et al. 360 (HUFU); idem, 14.IX.2004, fl. e fr., J. N. Nakajima et al. 3824 (HUFU).

Tibouchina heteromalla ocorre nos estados de São Paulo, Rio de Janeiro, Espírito Santo, Minas Gerais, Goiás, Pernambuco, Paraíba e Ceará. Esta espécie é encontrada em campo rupestre e cerrado rupestre das serras de Delfinópolis. Coletada com flores e frutos de março a maio e em setembro.

52. Trembleya phlogiformis DC., Prodromus 3:126. 1828.

Fig. $3 \mathrm{t}-\mathrm{u}$

Subarbustos, $40-80 \mathrm{~cm}$ alt. Ramos quadrangulares, nitidamente angulados. Indumento dos ramos, faces adaxial e abaxial das folhas, hipanto e lacínias do cálice pilosoglanduloso, com tricomas glandulares pedicelados, viscoso. Folhas opostas, pecíolo 2-3 mm compr.; lâmina 3,5-5,7 × 1-2 cm, concolor, elíptica, oboval-oblonga, ápice agudo, base atenuada a arredondada, margem serreado-ciliada, 2-3 pares de nervuras acródromas basais. Flores 5-meras, solitárias, terminais e axilares; pedicelo ca. $8 \mathrm{~mm}$ compr.; hipanto 5-5,5-3,5 mm, oblongo, urceolado; lacínias do cálice ca. $5 \times 0,5 \mathrm{~mm}$, lineares, ápice agudo, longo-apiculado, margem ciliadoglandulosa; pétalas 7,5-8×3-3,5 mm, creme, oboval-oblongas, ápice acuminado, margem ciliado-glandulosa no ápice; estames 10 , desiguais, creme, filetes glabros, anteras oblongas, uniporosas; estames antepétalos com filetes $2,5-3 \mathrm{~mm}$ compr., anteras $1,5-2 \times 0,5$ $\mathrm{mm}$, conectivo ca. $1 \mathrm{~mm}$ compr., prolongado abaixo das tecas, apêndice ventral ca. $0,3 \mathrm{~mm}$ compr., expandido; estames ante-sépalos com filetes 3-3,5 mm compr., anteras ca. $2 \times 0,5$ $\mathrm{mm}$, conectivo $2,5-3 \mathrm{~mm}$ compr. prolongado, apêndice ventral ca. $1 \mathrm{~mm}$ compr., expandido; ovário 5-locular, livre, ápice glabro; estilete ca. 4,5 mm compr., creme, filiforme, glabro, estigma truncado. Cápsula 4-8 $\times 2,5-4 \mathrm{~mm}$, marrom; sementes ca. $0,5 \mathrm{~mm} \times 0,2 \mathrm{~mm}$, curvas, superfície foveolada.

Material examinado: Fazenda Paraíso, trilha para Casinha Branca, 'Escada de Pedras', 11.IV.2002, fl., fr. e bot., R. A. Pacheco et al. 138 (HUFU); idem, 10.III.2003, fl., fr. ebot., $R$. L. Volpi et al. 537(HUFU).

Trembleya phlogiformis ocorre nos estados do Paraná, São Paulo, Rio de Janeiro, Minas Gerais, Mato Grosso do Sul, Mato Grosso, Goiás e Bahia. Esta espécie ocorre nos campos rupestres das serras de Delfinópolis. Coletada com flores e frutos nos meses de março e maio. 


\section{Conclusões}

As espécies que ocorrem em Delfinópolis pertencem a gêneros de distribuição ampla nas formações florestais do neotrópico, como Leandra, Miconia, Ossaea e Tibouchina e a gêneros bem representados nas formações rupestres das cadeias montanhosa do Brasil, como Cambessedesia, Chaetostoma, Lavoisiera, Marcetia, Microlicia e Trembleya.

O campo rupestre é a fitofisionomia predominante na região, onde foram encontradas 40 espécies de Melastomataceae, das quais 13 são exclusivas desta formação. Representantes da família também foram encontrados nas demais fitofisionomias amostradas (campo limpo, campo úmido, cerrado rupestre, mata de galeria, mata ciliar e mata mesófila semidecídua), com um número variável de espécies e hábitos.

Das 52 espécies de Melastomataceae encontradas nas serras de Delfinópolis, 15 apresentam distribuição ampla ocorrendo no Brasil e em outros países da América do Sul e/ou Central, 26 espécies ocorrem somente no território brasileiro e 10 espécies são endêmicas de Minas Gerais. Somente Svitramia integerrima é exclusiva dos campos rupestres das serras de Delfinópolis, formando pequenas populações. Lithobium cordatum e Microlicia canastrensis, endêmicas de Minas Gerais, estão na lista vermelha das espécies ameaçadas de extinção da flora de Minas Gerais (Mendonça \& Lins 2000).

\section{Agradecimentos}

As autoras agradecem a FAPEMIG pelo apoio financeiro para a realização das expedições de coleta às Serras de Delfinópolis e ao Dr. Paulo Eugênio de Oliveira, Dr. Jimi Naoki Nakajima e Dra. Fátima Regina Salimena pelas valiosas sugestões.

\section{REFERÊNCIAS BIBLIOGRÁFICAS}

Araújo, G. M.; Barbosa, A. A. A.; Arantes, A. A. \& Amaral, A. F. 2002. Composição florística de veredas no município de
Uberlândia, MG. Revista Brasileira de Botânica 25(2): 475-493.

Clausing, G. \& Renner, S. S. 2001. Molecular phylogenetics of Melastomataceae and Memecylaceae: implications for character evolution. American Journal of Botany 88(3): 486-498.

Drummond, G. M.; Martins, C. S.; Machado, A. B. M.; Sebaio, F. A. \& Antonini, Y. 2005. Biodiversidade em Minas Gerais: um atlas para a sua conservação. Fundação Biodiversitas, Belo Horizonte, 222p.

Durigan, G.; Baitelo, J. B.; Franco, G. A. D. C. \& Siqueira, M. F. 2004. Plantas do cerrado paulista: imagens de uma paisagem ameaçada. Páginas \& Letras, São Paulo, 475p.

Giulietti, A. M.; Menezes, N. L.; Pirani, J. R.; Meguro, M. \& Wanderley, M. G. L. 1987. Flora da Serra do Cipó: caracterização e lista das espécies. Boletim de Botânica da Universidade de São Paulo 9: 1-151.

Goldenberg, R. 2004. O gênero Miconia (Melastomataceae) no estado do Paraná, Brasil. Acta Botanica Brasilica 18(4): 927-947.

Guedes, M. L. S. \& Orge, M. D. R. 1998. Checklist das espécies vasculares do Morro do Pai Inácio (Palmeiras) e Serra da Chapadinha (Lençóis), Chapada Diamantina, Bahia, Brasil. Kew: UFBA/ RBG. Salvador, 68p.

IBGE. 2004. Instituto Brasileiro de Geografia e Estatística. www.ibge.gov.br. Acesso em 23/03/2006.

Martins, A. B.; Semir, J.; Goldenberg, R. \& Martins. E. 1996. O gênero Miconia Ruiz \& Pav. (Melastomataceae) no estado de São Paulo. Acta Botanica Brasilica 10(2): 267-315.

Matsumoto, K. \& Martins, A. B. 2005. Melastomataceae nas formações campestres do município de Carrancas, Minas Gerais. Hoehnea 32(3): 389-420.

Mendonça, M. P. \& Lins, L. V. 2000. Lista vermelha das espécies ameaçadas de extinção da flora de Minas Gerais. Fundação Biodiversistas, Belo Horizonte, 160p. 
Mendonça, R. C.; Felfili, J. M.; Walter, B. M. T.; Silva-Júnior, M. C.; Rezende, A. V.; Filgueiras, T. S. \& Nogueira, P. E. 1998. Flora vascular do Cerrado. In: Sano, S. M. \& Almeida, S. P. (eds.). Cerrado: ambiente e flora. EMBRAPA-CPAC, Brasília. Pp. 290-556.

Munhoz, C. B. R. 1996. Melastomataceae no Distrito Federal, Brasil: tribo Miconieae. A. P. De Candolle. Dissertação de Mestrado. Universidade de Brasília, Brasília, 178p.

Munhoz, C. B. R. \& Proença, C. E. B. 1998. Composição florística do município de Alto Paraíso de Goiás na Chapada dos Veadeiros. Boletim Herbário Ezechias Paulo Heringer 3: 102-150.

Pirani, J. R.; Giulietti, A. M.; Mello-Silva, R. \& Meguro, M. 1994. Checklist in patterns of geographic distribuition of the vegetation of Serra do Ambrósio, Minas Gerais, Brazil. Revista Brasileira de Botânica 17: 133-147.

Radford, A. 1986. Fundamentals of plant systematics. Harper \& Row, New York, 498p.

Ribeiro, J. F.; Silva, J. C. S. \& Batmanian, G. J. 1985. Fitossociologia de tipos fisionômicos de cerrado em Planaltina, DF. Revista Brasileira de Botânica 8(2): 131-142.

Ribeiro, J. F. \& Walter, B. M. T. 1998. Fitofisionomias do bioma cerrado. In: Sano, S. M. \& Almeida, S. P. (eds.). Cerrado: ambiente e flora. EMBRAPA-CPAC, Brasília. Pp. 89-166.
Romero, R. 1996. A família Melastomataceae na Estação Ecológica do Panga, município de Uberlândia, MG. Hoehnea 23(1): 147168.

Romero, R. 2000. A família Melastomataceae no Parque Nacional da Serra da Canastra, Minas Gerais, Brasil. Dissertação de Mestrado. Universidade Estadual de Campinas, Campinas, 325p.

Romero, R. \& Martins, A. B. 2002. Melastomataceae do Parque Nacional da Serra da Canastra, Minas Gerais, Brasil. Revista Brasileira de Botânica 25(1): 19-24.

Romero, R. \& Nakajima, J. N. 1999. Espécies endêmicas do Parque Nacional da Serra da Canastra, Minas Gerais. Revista Brasileira de Botânica 22 (2-suplemento): 259-265.

Santos, A. K. A. \& Silva, T. R. S. 2005. A família Melastomataceae no município de Rio de Contas, Bahia, Brasil. Sitientibus Série Ciências Biológicas 5(2): 76-92.

Siqueira, A. S.; Araújo, G. M. \& Schiavini, I. 2006. Caracterização florística da Reserva Particular do Patrimônio Natural (RPPN) Fazenda Carneiro, Lagamar, MG, Brasil. Biota Neotropica 6(3): 1-16.

Zappi, D. C.; Lucas, E., Stannard, B. L.; Lughadha, E. N.; Pirani, J. R.; Queiroz L. P.; Atkins, S.; Hind, D. J. N.; Giulietti, A. M.; Harley, R. M. \& Carvalho, A. M. 2003. Lista das plantas vasculares de Catolés - Chapada Diamantina, Bahia, Brasil. Boletim de Botânica da Universidade de São Paulo 21(2): 345-398. 